\title{
The EMEP MSC-W chemical transport model - technical description
}

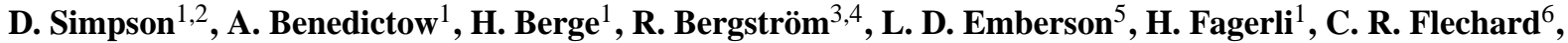 \\ G. D. Hayman ${ }^{7}$, M. Gauss ${ }^{1}$, J. E. Jonson ${ }^{1}$, M. E. Jenkin ${ }^{8}$, A. Nyíri ${ }^{1}$, C. Richter ${ }^{9}$, V. S. Semeena ${ }^{1}$, S. Tsyro ${ }^{1}$, \\ J.-P. Tuovinen ${ }^{10}$, Á. Valdebenito ${ }^{1}$, and P. Wind ${ }^{1,11}$ \\ ${ }^{1}$ EMEP MSC-W, Norwegian Meteorological Institute, Oslo, Norway \\ ${ }^{2}$ Dept. Earth \& Space Science, Chalmers Univ. Technology, Gothenburg, Sweden \\ ${ }^{3}$ Dept. Chemistry, Univ. of Gothenburg, Gothenburg, Sweden \\ ${ }^{4}$ Swedish Meteorological and Hydrological Institute, Norrköping, Sweden \\ ${ }^{5}$ Stockholm Environment Institute, University of York, York, England \\ ${ }^{6}$ INRA, Agrocampus Ouest, UMR 1069 SAS, Rennes, France \\ ${ }^{7}$ Centre for Ecology and Hydrology, Wallingford, Oxfordshire, OX10 8BB, UK \\ ${ }^{8}$ Atmospheric Chemistry Services, Okehampton, Devon EX20 1FB, UK \\ ${ }^{9}$ Gesellschaft für Anlagen- und Reaktorsicherheit (GRS) mbH, Cologne, Germany \\ ${ }^{10}$ Finnish Meteorological Institute, P.O. Box 503, 00101 Helsinki, Finland \\ ${ }^{11}$ University of Troms $\varnothing, 9037$ Troms $\varnothing$, Norway \\ Correspondence to: D. Simpson (david.simpson@met.no)
}

Received: 9 January 2012 - Published in Atmos. Chem. Phys. Discuss.: 2 February 2012

Revised: 1 August 2012 - Accepted: 16 August 2012 - Published: 31 August 2012

\begin{abstract}
The Meteorological Synthesizing Centre-West (MSC-W) of the European Monitoring and Evaluation Programme (EMEP) has been performing model calculations in support of the Convention on Long Range Transboundary Air Pollution (CLRTAP) for more than 30 years. The EMEP MSC-W chemical transport model is still one of the key tools within European air pollution policy assessments.

Traditionally, the model has covered all of Europe with a resolution of about $50 \mathrm{~km} \times 50 \mathrm{~km}$, and extending vertically from ground level to the tropopause $(100 \mathrm{hPa})$. The model has changed extensively over the last ten years, however, with flexible processing of chemical schemes, meteorological inputs, and with nesting capability: the code is now applied on scales ranging from local (ca. $5 \mathrm{~km}$ grid size) to global (with 1 degree resolution). The model is used to simulate photooxidants and both inorganic and organic aerosols.

In 2008 the EMEP model was released for the first time as public domain code, along with all required input data for model runs for one year. The second release of the EMEP MSC-W model became available in mid 2011, and a new release is targeted for summer 2012. This publication is in-
\end{abstract}

tended to document this third release of the EMEP MSC-W model. The model formulations are given, along with details of input data-sets which are used, and a brief background on some of the choices made in the formulation is presented. The model code itself is available at www.emep.int, along with the data required to run for a full year over Europe.

\section{Introduction}

The European Monitoring and Evaluation Programme for Transboundary Long-Range Transported Air Pollutants (EMEP) started in 1977, a successful initiative between almost all European countries to pool efforts in tackling the major environmental problem of the day, acid deposition. When the Convention on Long-range Transboundary Air Pollution (CLRTAP, www.unece.org/env/lrtap) was established in 1979, EMEP became an integrated part of the Convention, and has since played an important part in the development of emission reduction scenarios, for both the 
Convention (now comprising 51 Parties, including USA and Canada) and the European Commission.

The Meteorological Synthesizing Centre-West (MSC-W), based in Oslo, is one of two modelling centres established by EMEP, with main responsibility for photo-oxidant and aerosol modelling. The other modelling centre, MSC-East, is based in Moscow and focuses on heavy metals and persistant organic pollutants. A third Centre, EMEP Chemical Coordinating Centre (CCC) takes care of the EMEP measurement network, and provides the main source of data against which the chemical transport models (CTMs) of EMEP are evaluated (Tørseth et al., 2012). The CTM used at EMEP MSC-W is a 3-D Eulerian model, typically used to tackle problems within the fields of acid deposition, tropospheric ozone, and particles. Results from this model are provided to the International Institute for Applied Systems Analysis (IIASA), providing the atmospheric chemistry results that underpin the GAINS integrated assessment model (http://www.iiasa.ac.at/rains/gains.html).

The last full documentation of the model was Simpson et al. (2003a). Since that time there have been numerous changes, sometimes involving a complete revision of the methodology used (e.g. dry deposition for particles, emissions of hydrocarbons from vegetation, $\mathrm{NO}$ emissions from soils, co-deposition of $\mathrm{SO}_{2}$ and $\mathrm{NH}_{3}$, calculation of mixing heights, or introduction of $\mathrm{pH}$ response during sulphate formation), and sometimes involving smaller changes in the equations or parameters values. Further, the scope of application of the model has increased enormously. Traditionally, the EMEP model covered all of Europe with a resolution of about $50 \mathrm{~km} \times 50 \mathrm{~km}$, and extending vertically from ground level to the tropopause $(100 \mathrm{hPa})$. The model is now applied on scales ranging from local (ca. $5 \mathrm{~km}$ grid size) to global (with 1 degree resolution). The model can now be driven by several different numerical weather prediction or climate models, and has a nesting capability, allowing for example the zooming from $50 \mathrm{~km}$ to $5 \mathrm{~km}$ scale in the EMEP4UK work of Vieno et al. $(2009,2010)$.

Some of the background for these changes (and some experimental ones) can be found in several recent papers. These include testing of organic aerosol schemes (Bergström et al., 2012), sea-salt modelling (Tsyro et al., 2011), water-content of aerosols (Tsyro, 2005), ozone deposition (Tuovinen et al., 2004, 2009; Tuovinen and Simpson, 2008), aerosol deposition schemes (Flechard et al., 2011), boundary layer physics (Jeričevič et al., 2010) or soil water modelling (Büker et al., 2011). The chemical schemes mentioned in section Sect. 7 have been compared and a write-up is in progress (Hayman et al., 2012).

The model performance compared to EMEP and other measurements is presented annually in EMEP validation reports, available from www.emep.int, e.g. Gauss et al. (2011). More in-depth discussion can be found in a number of papers. Comparisons for sulphur and nitrogen compounds can be found in Simpson et al. (2006a,b) and Fagerli and Aas
(2008). Comparison against trends of inorganic species and EC can be found in Fagerli et al. (2007) and for ozone in Jonson et al. (2006a). Aas et al. (2012) present comparison against AMS and other data-sets during the first so-called EMEP intensive measurement period. Comparisons for large scale $\mathrm{CO}$ (and to a lesser extent $\mathrm{C}_{2} \mathrm{H}_{6}$ ) have been presented in Angelbratt et al. (2011). The regional forecasts of the EMEP MSC-W model are also constantly under evaluation within the MACC project (Valdebenito and Benedictow, 2011). A discussion of the fine-scale applications and performance of the model can be found in Vieno et al. (2009) and Vieno et al. (2010). Further, the EMEP model has been taking part in a large number of inter-comparisons in recent years (e.g. Cuvelier et al., 2007; Fiore et al., 2009; Huijnen et al., 2010; Jonson et al., 2010a; Colette et al., 2011, 2012; Langner et al., 2012).

Given that the EMEP model is being used in a wide range of scientific and policy contexts, there is an urgent need to provide a full description of the model as it is now, and indeed as used in many of the above papers. A short summary of the changes from the 2003 to 2012 model versions can be found in the Supplement, Sect. S1, but the intention of this paper is to present a detailed documentation of the EMEP MSC-W modelling system as it is now. The formulations used by the model are given, along with some details of input data-sets. The aim of this paper is to provide a concise description, rather than discussion, of the model - the latter is left for more extended reports and publications on specific subjects. However, the background to a few of the more recent changes to the model is presented briefly.

Some of the more technical descriptions and tables are provided as a Supplement. For convenience, Table 1 provides an overview of some of the main symbols and abbreviations used in this article.

\subsection{Short history}

Eliassen et al. (1982) and Eliassen and Saltbones (1983) presented the first long-range transport model within the EMEP framework. The model was Lagrangian, developed for modelling sulphur compounds, and covered the whole of Europe using a $150 \mathrm{~km} \times 150 \mathrm{~km}$ grid. This model was further developed for nitrogen compounds (Hov et al., 1988; Iversen, 1990), and ozone (Simpson, 1993, 1995). Eulerian models were subsequently developed for acidification (Berge and Jakobsen, 1998), and photo-oxidants (Jonson et al., 1997, 1998, 2001). In Simpson et al. (2003a) the first "unified" EMEP model was presented, in which one Eulerian model code was developed for both acidification and photo-oxidant activities.

In 2008 version rv3.0 of the EMEP model was released as public domain code, along with all required input data for model runs for one year. The second release of the EMEP MSC-W model, denoted EMEP MSC-W version rv3.7 became available in mid 2011, and a new release, rv4.0, is 
targeted for summer 2012. Recent changes have included the addition to the standard EMEP model of a number of new aerosol components, including organic aerosol (OA), dust and sea-salt. Other major changes are given in Table S1 of the Supplement.

This publication is intended to document this third release of the EMEP MSC-W model, denoted rv4.0, although most of the material is also relevant for the rv3.7 and later codes. The model code itself can be obtained through www.emep.int.

\section{Physical description}

\subsection{Domain and model-coordinates}

The basic physical formulation of the EMEP model is derived from that of Berge and Jakobsen (1998), although it is now rather flexible in its horizontal grid specification. The model derives its horizontal and vertical grid from the input meteorological data (Sect. 3). A polar-stereographic projection, true at $60^{\circ} \mathrm{N}$, has commonly been used, with grid-size of $50 \mathrm{~km} \times 50 \mathrm{~km}$ at $60^{\circ} \mathrm{N}$. The standard domain has changed somewhat over the years, and was enlarged from 2007; details of this projection and the conversion to and from latitude-longitude are given elsewhere (http://www. emep.int).

Other configurations are commonly used, such as $5 \mathrm{~km} \times 5 \mathrm{~km}$ grid-sizes for the EMEP4UK project (Vieno et al., 2010), $1^{\circ} \times 1^{\circ}$ for global modelling (Jonson et al., 2010a,c), and $0.2^{\circ} \times 0.2^{\circ}$ for regional forecasts under the MACC project (Valdebenito and Benedictow, 2011).

The input meteorological data are required to be defined (or interpolated) at the model vertical levels. These are currently defined vertically with so-called $\sigma$ coordinates:

$\sigma=\frac{p-p_{\mathrm{T}}}{p^{*}}$

where $p^{*}=p_{\mathrm{S}}-p_{\mathrm{T}}$ and $p, p_{\mathrm{S}}$ and $p_{\mathrm{T}}$ are the pressure at level $\sigma$, at the surface, and at the top of the model domain (currently $100 \mathrm{hPa}$ ), respectively. The model currently uses 20 vertical levels, as illustrated in Fig. 1. The lowest two layers in this system are shown in Fig. 2, with the $\sigma$ levels from Fig. 1 as solid lines, and the "mid"-layers for which meteorology is generally provided as dashed lines. Diffusion coefficients and vertical velocity, given by $\dot{\sigma}(=d \sigma / d t)$, are valid for the layer boundaries.

\subsection{The continuity equation}

If we let $\chi$ represent the mass mixing ratio ( $\mathrm{kg}$ pollutant per $\mathrm{kg}$ air) of any pollutant, the continuity equation may be written:
Table 1. List of frequently used symbols and acronyms.

\begin{tabular}{|c|c|}
\hline EMEP & $\begin{array}{l}\text { European Monitoring and Evaluation } \\
\text { Programme (Full name: Cooperative } \\
\text { Programme for Monitoring and Evalua- } \\
\text { tion of the Long-range Transmission of } \\
\text { Air Pollutants in Europe) }\end{array}$ \\
\hline CLRTAP & $\begin{array}{l}\text { Convention on Long Range Trans- } \\
\text { boundary Air Pollution }\end{array}$ \\
\hline LRTAP & LRTAP Convention, as CLRTAP \\
\hline MSC-W & $\begin{array}{l}\text { Meteorological Synthesizing Centre - } \\
\text { West }\end{array}$ \\
\hline UN-ECE & $\begin{array}{l}\text { United Nations Economic Commission } \\
\text { for Europe }\end{array}$ \\
\hline IIASA & $\begin{array}{l}\text { International Institute for Applied Sys- } \\
\text { tems Analysis }\end{array}$ \\
\hline IAM & Integrated assessment modelling \\
\hline CTM & Chemical transport model \\
\hline NWP & Numerical weather prediction \\
\hline ECMWF IFS & $\begin{array}{l}\text { NWP model used by the European Cen- } \\
\text { tre for Medium Range Weather Fore- } \\
\text { casting. }\end{array}$ \\
\hline NMVOC & $\begin{array}{l}\text { Non-methane volatile organic } \\
\text { compounds }\end{array}$ \\
\hline $\mathrm{NO}_{\mathrm{x}}$ & Nitrogen oxides, $\mathrm{NO}+\mathrm{NO}_{2}$ \\
\hline$T_{2}$ & air temperature at $2 \mathrm{~m}$ height, \\
\hline$k$ & von Karman's constant (0.4) \\
\hline SGS, $d_{\mathrm{SGS}}$ & Start of growing season, daynumber \\
\hline $\mathrm{EGS}, d_{\mathrm{EGS}}$ & End of growing season, daynumber \\
\hline PLA & Projected leaf area \\
\hline LAI & $\begin{array}{l}\text { Leaf area index }\left(\mathrm{m}^{2} \mathrm{~m}^{-2}\right) \text {, one-sided } \\
\text { projected (also known as PLA) }\end{array}$ \\
\hline SAI & Surface area index $\left(\mathrm{m}^{2} \mathrm{~m}^{-2}\right)$ \\
\hline PAR & $\begin{array}{l}\text { Photosynthetic active radiation (400- } \\
700 \mathrm{~nm} \text { ) }\end{array}$ \\
\hline$\Lambda_{\mathrm{c}}$ & EMEP land-cover category, see Table 3 \\
\hline$r_{x}$ & $\begin{array}{l}\text { specific resistance term, per } \mathrm{m}^{2} \text { PLA, } \\
\text { for pathway } x\end{array}$ \\
\hline$R_{x}$ & bulk canopy resistance term \\
\hline$g, G$ & $\begin{array}{l}\text { conductance terms, reciprocal of } r, R \text {. } \\
\text { Two important terms are: }\end{array}$ \\
\hline$g_{\text {sto }}$ & stomatal conductance \\
\hline$G_{\mathrm{ns}}$ & bulk canopy non-stomatal conductance \\
\hline$V_{\mathrm{g}}$ & deposition velocity \\
\hline$\chi$ & concentration (mixing ratio) \\
\hline$z_{\text {ref }}$ & $\begin{array}{l}\text { reference height (ca. } 45 \mathrm{~m} \text { ) for deposi- } \\
\text { tion calculations }\end{array}$ \\
\hline$d$ & displacement height \\
\hline$z_{0}$ & roughness length \\
\hline$L$ & Obukhov length \\
\hline$u_{*}$ & friction velocity \\
\hline
\end{tabular}




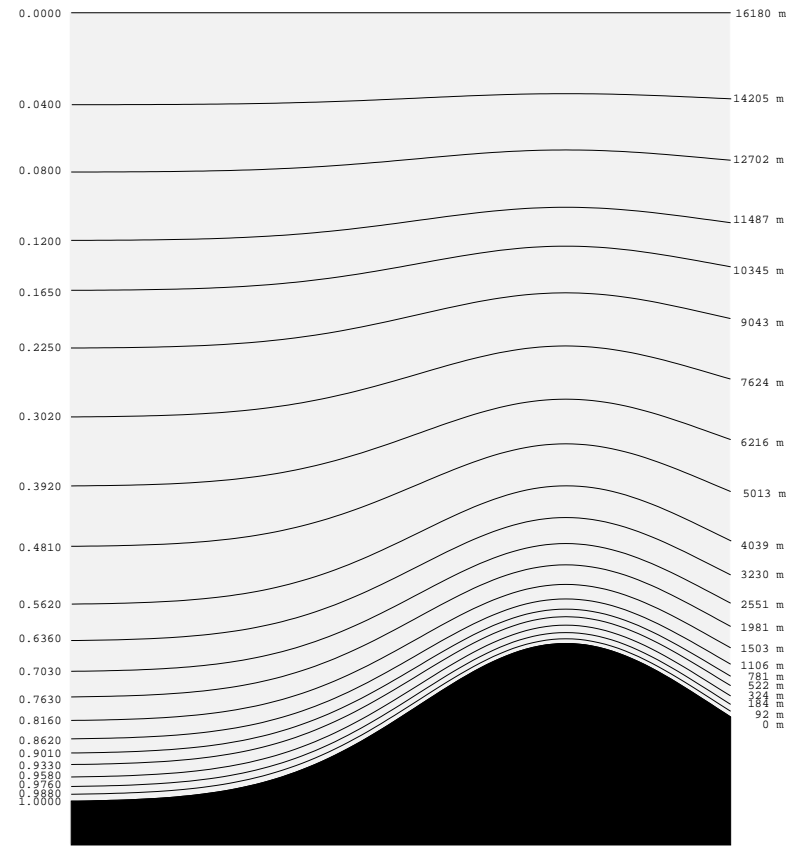

Fig. 1. Vertical structure of the EMEP model. The troposphere is represented in the model by $20 \sigma$ layers. Sigma values for the boundaries of each level are shown on the left hand side of the figure. The corresponding height above the ground, computed for a standard atmosphere, is given on the right-hand side.

$$
\begin{aligned}
\frac{\partial}{\partial t}\left(\chi p^{*}\right)= & -m_{x} m_{y} \frac{\partial}{\partial x}\left(\frac{u}{m_{y}} \chi p^{*}\right) \\
& -m_{x} m_{y} \frac{\partial}{\partial y}\left(\frac{v}{m_{x}} \chi p^{*}\right) \\
& -\frac{\partial}{\partial \sigma}\left(\dot{\sigma} \chi p^{*}\right)+\frac{\partial}{\partial \sigma}\left[K_{\sigma} \frac{\partial}{\partial \sigma}\left(\chi p^{*}\right)\right]+\frac{p^{*}}{\rho} S
\end{aligned}
$$

The first three terms on the right hand side represent a flux divergence formulation of the advective transport. $u, v$ are the horizontal wind components, and $m_{x}, m_{y}$ are the map factors in the $\mathrm{x}$ and $\mathrm{y}$ directions $\left(m_{x}=m_{y}\right.$ in a conformal projection like polar-stereographic). The vertical velocity, $\dot{\sigma}$ equals $\mathrm{d} \sigma / \mathrm{d} t$.

The 4th term on the right hand side of Eq. (3) represents the vertical eddy diffusion $K_{\sigma}$ coefficient in $\sigma$-coordinates. Horizontal eddy diffusion is not included in the model. In the 5th term, $S$ includes the chemical and other (convection, deposition etc.) source and sink terms.

The numerical solution of the advection terms is based upon the scheme of Bott (1989a,b). The fourth order scheme is utilized in the horizontal directions. In the vertical direction a second order version applicable to variable grid distances is employed.

In our scheme the "air" ( $\chi_{\text {air }}=1 \mathrm{~kg} \mathrm{~kg}^{-1}$ ) is also advected. After each advection step the new mixing ratios are

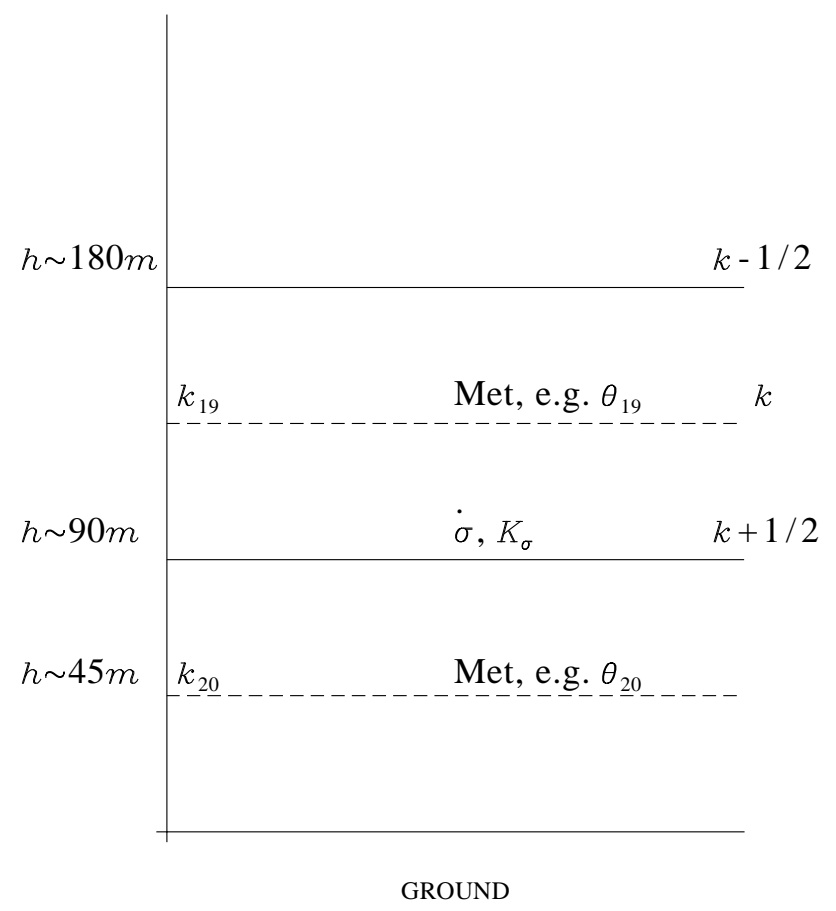

Fig. 2. Lowest levels of the EMEP model, showing the layer boundaries at $90 \mathrm{~m}, 180 \mathrm{~m}$ (cf. Fig. 1) and the "mid"-layers for which meteorology is generally provided.

found by dividing the result by the new "air concentrations": $\left(\chi_{x}\right)^{t+\Delta t}=\frac{\left(\chi_{x} p^{*}\right)^{t+\Delta t}}{\chi_{\text {air }}^{t+\Delta t}}$, where $\left(\chi_{x} p^{*}\right)^{t+\Delta t}$ is the result obtained with the Bott-scheme for component $x$ after a timestep $\Delta t$. This method ensures that, starting with a constant mixing ratio, the result will also be a constant mixing ratio, regardless of the complexity of the wind-fields.

The EMEP model's advection scheme is not monotonic, because a monotonicity filter may increase the numerical diffusion. However the scheme will exclude possible negative values of the mixing ratios. The time steps are adapted to the choice of the grid resolution and meteorological data. This work is described in more detail in Wind et al. (2002), and a brief outline is presented in the Supplement, Sect. S2.2.

\subsection{Convection}

An optional (see below) convective mass flux scheme has been implemented in the EMEP model, based on Tiedtke (1989). The implementation is virtually identical to the method used in the Oslo CTM2 model (Berglen et al., 2004), and was originally developed by M. Prather and B. Hannegan, University of California at Irvine (UCI). From the meteorological input data, convective updraft mass flux is provided at every level in each model column and the convective transport of pollutants mass is calculated by the so called elevator principle. The entrainment of air to the updraft cloud core from the surrounding air is calculated as the difference 


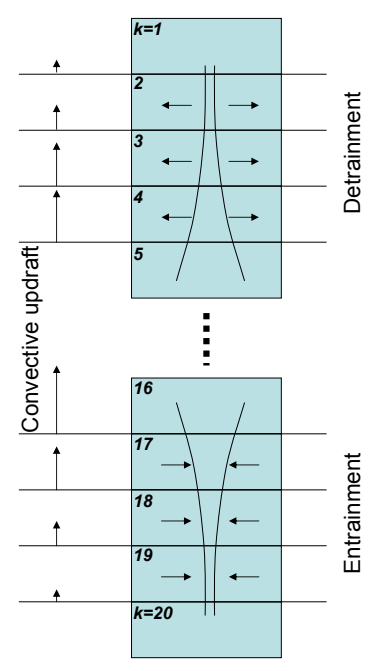

Convective updraft vertical mass flux at top of the grid cell is smaller than at its bottom

$\rightarrow$ dump updraft core air into ambient (detrainment)

Convective updraft vertical mass flux at top of the grid cell is larger than at its bottom

$\rightarrow$ bring ambient air into the updraft core (entrainment)

Fig. 3. Illustration of convective updrafts. Convective downdrafts are treated similarly.

in convective mass flux through the upper and lower boundary of a given grid box, and may be visualised as an elevator stopping at each model layer for air, humidity and pollutant mass to get on or off as illustrated in Fig. 3 (negative entrainment is referred to as detrainment). Vertical transport through convection is much faster than through large scale advection.

As illustrated in Fig. 3 the updraft core will typically gain momentum in the lowest model layers, resulting in a net entrainment, visualised by the upward pointing errors to the left in the lower part of the figure, and lose momentum higher up, resulting in net detrainment. The downdraft core is treated in an analogous way. Within one grid column the downdraft flux is typically about a factor of 10 smaller than the upward flux. The net difference between updraft and downdraft fluxes is treated as a slow subsiding motion. The numerical implementation of the convective routines is described in the Supplement, Sect. S2.1.

Convection is an important process in atmospheric dynamics, but very difficult to parameterise in CTMs (Stevenson et al., 2006). Willett et al. (2008), Zhao et al. (2009) and Monks et al. (2009) (and references cited therein) give examples where significant differences in precipitation and mass transport were found between different parameterisations of convection in NWP models. Used with global-scale IFS meteorological data, the convection module seems to give more realistic results compared to measurements. However, we find that if used with European-scale simulations, we obtain somewhat worse model results compared to observations. This is of course an unsatisfactory situation, but given that all cumulus schemes in NWP models have major uncertainties, we adopt a pragmatic approach and by default switch convection off for the European scale, and on for global scale. The option to switch this module on and off in any case affords some valuable information on the impor- tance of convection, and the uncertainties associated with its implementation.

\subsection{Nesting}

The EMEP MSC-W model now supports 1-way nesting, in which the results of larger-scale runs of the EMEP (or indeed of any other comparable CTM) model can be used as boundary conditions for smaller scale runs. This procedure is most heavily used in the EMEP4UK project (e.g. Vieno et al., 2010), where model runs with $5 \mathrm{~km}$ grids over the United Kingdom are nested within larger domain runs of $10 \mathrm{~km}$, which in turn are nested within European scale runs using $50 \mathrm{~km}$ grids. (Other configurations are also used). Of course, appropriate meteorological and other data are required for all nesting levels, and for EMEP4UK the WRF (Skamarock and Klemp, 2008) model is used to obtain the necessary data.

\section{Meteorology}

During the last few years the EMEP model has been adapted to run with meteorological fields from a number of numerical weather prediction models (NWPs), including PARLAM-PS (Lenschow and Tsyro, 2000; Bjørge and Skålin, 1995; Benedictow, 2003), HIRLAM version version 7.1.3 (Undén et al. 2002, http://hirlam.org/) and ECMWF-IFS Cycle36r1 (http: //www.ecmwf.int/research/ifsdocs/). In 2009 the ECMWFIFS became available to run with the T799 $0.22^{\circ} \times 0.22^{\circ}$ horizontal spectral resolution and 60 vertical levels on a global domain, and from 2011 we have adopted this model as the default meteorological driver.

For higher resolution modelling, both the EMEP4UK and EMEP4HR projects make use of EMEP model's nesting capabilities (Sect. 2.4) together with the WRF and Aladin models as meteorological drivers - see Vieno et al. (2010), Jeričevič et al. (2010), and associated references for more details.

Regional pollution forecasts under the MACC project are driven by ECMWF-IFS operational forecasts (http: //www.ecmwf.int/products/data/technical/model_id/). As of Nov. 2011, these data are available for forecasts with T1279 $0.14^{\circ} \times 0.14^{\circ}$ horizontal spectral resolution and 91 vertical levels (currently Cycle37r3; 15 November 2011).

Meteorological data are normally required at 3-hourly intervals for the EMEP model. Given the wide range of meteorological drivers, which do not all provide all desired model inputs, the EMEP model has systems for deriving parameters when missing, or can do without some meteorological fields. Table 2 summarises the meteorological fields currently used in the EMEP model, and indicates optional fields (one of these, soil moisture index, is briefly discussed in Sect. 3.3). Most 3-D fields are provided at the centre of each model layer, as illustrated in Fig. 2. The horizontal wind components $(u$ and $v$ ), and the vertical wind component $\dot{\sigma}$, are given 
on a staggered Arakawa C-grid (Arakawa and Lamb, 1977). The vertical velocity, given by $\dot{\sigma}$, is provided at the layer boundaries. All other variables are given in the centre of the grid cells. If the vertical wind velocity is not directly available, it is derived from the horizontal wind components and the continuity equations.

Linear interpolation between the 3-hourly values is used to calculate values of these parameters at each advection step. A number of other parameters are derived from these, for example air density, $\rho$, and the stability parameters and boundary layer heights described below.

Solar radiation is also calculated at every time-step for the deposition calculations, and for photolysis rates, based upon instantaneous values of the solar zenith angle and the model's cloud cover, see Sect. 4.

\subsection{Boundary layer height $\left(Z_{\mathrm{PBL}}\right)$}

In general, we characterise the thermal stability of the atmosphere by the bulk Richardson number, which is defined for the layer between any two model levels at heights $z_{j}$ and $z_{k}$ as

$R i_{j, k}=\frac{g \Delta z_{j, k} \Delta \theta_{j, k}}{\overline{\theta_{j, k}} \Delta V_{\mathrm{H}, j, k}^{2}}$

where $g$ is the acceleration due to gravity, $\Delta z_{j, k}=z_{j}-z_{i}$, $\theta$ is the potential temperature, $\Delta \theta_{j, k}=\theta\left(z_{j}\right)-\theta\left(z_{k}\right), \overline{\theta_{j, k}}=$ $\left(\theta\left(z_{j}\right)+\theta\left(z_{k}\right)\right) / 2$, and $\Delta V_{\mathbf{H}, j, k}=\boldsymbol{V}_{\mathbf{H}}\left(z_{j}\right)-\boldsymbol{V}_{\mathbf{H}}\left(z_{k}\right)$ is the difference in horizontal velocity vectors.

Following Jeričevič et al. (2010), the mixing height calculation uses a slightly modified bulk Richardson number, $R i_{\mathrm{B}, j}$, in which $z_{k}$ is always the lowest level (ca. $45 \mathrm{~m}$, cf. $k_{20}$ in Fig. 2), but the wind-velocity gradient is referred to ground-level (where $V_{\mathrm{H}}(0)=0$ ), thus $\Delta V_{\mathrm{H}, j, 0}=V_{\mathrm{H}, j}$. The mixing height is defined as the lowest height $z_{\mathrm{PBL}}=z_{j}$ at which $R i_{\mathrm{B}, j}>0.25$. This formulation is significantly simpler than that used in previous EMEP model versions, and has been shown to provide results which are at least as good (Jeričevič et al., 2010). The method is also very similar to the bulk Richardson number approach used in Seibert et al. (2000), which compared favourably with other methods.

Finally, the PBL height is smoothed with a second order Shapiro filter in space (Shapiro, 1970). The PBL height is not allowed to be less than $100 \mathrm{~m}$ or exceed $3000 \mathrm{~m}$.

\subsection{Eddy diffusion coefficients $\left(K_{z}\right)$}

The initial calculation of the vertical exchange coefficients $\left(K_{z}\right.$, units $\left.\mathrm{m}^{2} \mathrm{~s}^{-1}\right)$ is done for the whole 3-D domain, using:

$K_{z}=\left\{\begin{array}{cc}1.1\left(R i_{\mathrm{crit}, k}-R i\right) \ell^{2}\left|\Delta V_{\mathrm{H}} / \Delta z\right| / R i_{\mathrm{c}}, & \text { for } R i \leq R i_{\mathrm{c}} \\ K_{\min } & , R i>R i_{\mathrm{c}}\end{array}\right.$

where the critical Richardson number $R i_{\mathrm{c}}$ is given by: $R i_{\text {crit }, k}=A\left(\Delta z_{k} / \Delta z_{0}\right)^{\mathrm{B}}, \quad A=0.115, \quad B=0.175$ and
$\Delta z_{0}=0.01 \mathrm{~m}$ (Pielke, 2002), $\ell$ is the turbulent mixing length, and $\Delta V_{\mathrm{H}}$ represents the difference in wind-speed between two grid-cell centres separated by distance $\Delta z$, and $K_{\min }=0.001 \mathrm{~m}^{2} \mathrm{~s}^{-1}$. The numerical values follow from the suggestions of Blackadar (1979) and Pielke (2002).

The turbulent mixing length, $\ell$, is parameterized according to:

$\ell=k z, z \leq z_{m}$

$\ell=k z_{m}, z>z_{m}$

where $k$ is the von Karman's constant $(0.41), z$ is the height above the ground and $z_{m}=200 \mathrm{~m}$.

Below the mixing height $z_{\mathrm{PBL}}$, these $K_{z}$ values are recalculated. For neutral and stable conditions the simple formulation of Jeričevič et al. (2010) is used, whereby:

$K_{z}(z)=0.39 u_{*} z \exp \left(-0.5\left(z / 0.21 z_{\mathrm{PBL}}\right)^{2}\right)$

for $z<z_{\mathrm{PBL}}$. The values 0.39 and 0.21 are empirical constants derived from large eddy simulation experiments. $u_{*}$ is the friction velocity provided by the NWP model $(=\sqrt{\tau / \rho}$, $\mathrm{ms}^{-1}$ ).

For unstable situations, new $K_{z}$ values are calculated for layers below the mixing height using the O'Brien (1970) profile:

$$
\begin{aligned}
K_{z}(z)= & K_{z}\left(z_{\mathrm{PBL}}\right)+\left(\frac{z_{\mathrm{PBL}}-z}{z_{\mathrm{PBL}}-h_{\mathrm{s}}}\right)^{2} \\
& \left\{K_{z}\left(h_{\mathrm{s}}\right)-K_{z}\left(z_{\mathrm{PBL}}\right)\right. \\
& \left.+\left(z-h_{\mathrm{S}}\right)\left[\frac{\delta}{\delta z}\left(K_{z}\left(h_{\mathrm{s}}\right)\right)+2 \frac{K_{z}\left(h_{\mathrm{s}}\right)-K_{z}\left(z_{\mathrm{PBL}}\right)}{z_{\mathrm{PBL}}-h_{\mathrm{S}}}\right]\right\} \\
& \left(h_{\mathrm{s}} \leq z<z_{\mathrm{PBL}}\right)
\end{aligned}
$$

in which $h_{\mathrm{s}}$ is the height of the surface layer (or the socalled constant flux layer), which we set to be $4 \%$ of the mixing height $z_{\mathrm{PBL}}$ (Pielke, 2002). From the similarity theory of Monin-Obukhov (e.g. Stull, 1988; Garratt, 1992) we have

$K_{z}(z)=\frac{u_{*} k z}{\Phi_{h}\left(\frac{z}{L}\right)} \quad z<h_{\mathrm{s}}$

where $\Phi_{h}$ is the atmospheric stability function for temperature, assumed valid for all scalars. The latter is derived using standard similarity theory profiles (Garratt, 1992). The Obukhov length is given by:

$L=-\frac{T_{2} u_{*}^{3} \rho c_{p}}{k g H}$

where $c_{p}$ is the specific heat capacity of dry air $\left(1005 \mathrm{~J} \mathrm{~kg}^{-1} \mathrm{~K}^{-1}\right)$, and $\rho$ is air density. The sign here is consistent with $H$ directed away from the surface (positive $H$ gives unstable conditions).

Finally, in sigma coordinates, the diffusion coefficient has the following form:

$K_{\sigma}=K_{z} \rho^{2}\left(\frac{g}{p^{*}}\right)^{2}$ 
Table 2. Meteorological Data Used in EMEP Model.

\begin{tabular}{|c|c|c|c|c|}
\hline Name & Unit & Type $^{\mathrm{a}}$ & Main Purpose & Notes \\
\hline \multicolumn{5}{|l|}{ 3-D fields - for $20 \sigma$ levels: } \\
\hline Horizontal wind velocity components & $\mathrm{ms}^{-1}$ & Inst. & Advection & \\
\hline Specific humidity & $\mathrm{kg} \mathrm{kg}^{-1}$ & Inst. & Chemical reactions, dry deposition & \\
\hline Potential temperature & $\mathrm{K}$ & Inst. & Chemical reactions, eddy diffusion & \\
\hline Precipitation & $\mathrm{mm}$ & Acc. & Wet and dry deposition & $\mathrm{b}$ \\
\hline Cloud cover & $\%$ & Avg. & Wet removal, photolysis & \\
\hline Vertical wind in $\sigma$ coordinates & $\mathrm{s}^{-1}$ & Inst. & Vertical advection & \\
\hline Convective updraft flux & $\mathrm{kg} \mathrm{m}^{-2} \mathrm{~s}^{-1}$ & Avg. & Vertical transport, wet removal & d \\
\hline Convective downdraft flux & $\mathrm{kg} \mathrm{m}^{-2} \mathrm{~s}^{-1}$ & Avg. & Vertical transport, wet removal & d \\
\hline \multicolumn{5}{|l|}{ 2-D fields - for surface: } \\
\hline Surface pressure & $\mathrm{hPa}$ & Inst. & Air density, definition of vertical levels & \\
\hline Temperature at $2 \mathrm{~m}$ height & $\mathrm{K}$ & Inst. & Dry deposition, stability & \\
\hline Surface flux of sensible heat & $\mathrm{W} \mathrm{m}^{-2}$ & Inst. & Dry deposition, stability & \\
\hline Surface flux of latent heat & $\mathrm{W} \mathrm{m}^{-2}$ & Inst. & Dry deposition & \\
\hline Surface stress or friction velocity & $\mathrm{N} \mathrm{m}^{-2}$ or $\mathrm{ms}^{-1}$ & Inst. & Dry deposition, stability & \\
\hline Snow depth & $\mathrm{m}$ & Inst. & Dry deposition & \\
\hline Fraction of ice cover & $\%$ & Inst. & Dry deposition & \\
\hline Sea surface temperature & $\mathrm{K}$ & Inst. & Sea salt & $\mathrm{e}$ \\
\hline 10-m wind-speed & $\mathrm{ms}^{-1}$ & Inst & Sea-salt & $\mathrm{f}$ \\
\hline Soil water, near surface & - & Inst. & Dust emissions & $\mathrm{g}$ \\
\hline Soil water, root zone & - & Inst. & Dry deposition & $\mathrm{g}$ \\
\hline
\end{tabular}

a Types refer to time-averaging of data: Inst=instantaneous, Acc $=$ accumulated (over $3 \mathrm{~h}$ ), Avg = averaged (over 3 h); ${ }^{b}$ these data are frequently not available from NWP models as 3-D fields. If unavailable, 3-D precipitation is derived from surface precipitation - see Supplement, Sect. S3.1; ${ }^{\mathrm{c}}$ if not available, calculated, see Sect. S3.2; d the convective routine is optional in the model, but if switched on these parameters are required; ${ }^{\mathrm{e}} 2$-m temperature, $T_{2}$, used if not available; ${ }^{\mathrm{f}}$ calculated from 3-D winds if not available; ${ }^{\mathrm{g}}$ See Sect. 3.3. If not available, soils assumed to be moist.

\subsection{Soil water}

Soil water (SW) is very difficult to model accurately in largescale models, since it depends very much on assumptions concerning parameters such as soil texture, and vegetation characteristics such as rooting depth that are not generally amenable to measurements (e.g. Baker, 2003; Büker et al., 2011; Miller et al., 2007). Different NWP models also make use of very different schemes for soil water, depending on the complexity of the underlying vegetation schemes, and these models provide different outputs - sometimes SW in terms of volumetric amount (e.g. from HIRLAM), sometimes in terms of a soil moisture index (ECMWF, discussed below). Volumetric outputs can be difficult to interpret unless the associated soil and vegetation characteristics are known for that NWP.

Soil moisture is important though for dry-deposition and dust emission rates, so we have implemented a procedure which unifies the treatment from different NWP models. The exact methodology depends on the NWP model and its SW outputs, but essentially we define minimum and maximum soil water amounts to be $\mathrm{SW}_{\text {min }}$ (identified with wilting points for example) and $\mathrm{SW}_{\max }$ (identified with field capacity), which may be constant over an NWP domain, or vary spatially, and then define the soil moisture index (which we previously denoted as relative extractable water index), as:

$S_{\mathrm{MI}}=\left(\mathrm{SW}-\mathrm{SW}_{\min }\right) /\left(\mathrm{SW}_{\max }-\mathrm{SW}_{\min }\right)$.

The index $S_{\mathrm{MI}}$ has the advantage over volumetric methods that it is less sensitive to local soil characteristics, and hence is easier to interpolate across different vegetation types and grids. For example, a reasonable estimate of volumetric SW can be made given local values for $\mathrm{SW}_{\min }$ and $\mathrm{SW}_{\max }$, if $S_{\mathrm{MI}}$ is known.

The ECMWF IFS data we now use by default provides $S_{\mathrm{MI}}$ values directly; these are available for the near-surface (ca. $10 \mathrm{~cm})$ and deeper $(1 \mathrm{~m})$ soil layers, which we use for dust and dry-deposition modules, respectively.

\section{Radiation}

Calculation of direct and diffuse radiation is needed for chemical photolysis rates (Sect. 7.3), and in addition, calculation of photosynthetically active radiation (PAR) is needed for calculating biogenic VOC emissions (Sect. 6.6), and for calculation of stomatal conductance for dry deposition or ozone uptake modelling (Sect. 8). 
Table 3. Land-cover classes used in EMEP model, with default heights $(h)$, growing-season, LAI and BVOC related-parameters.

\begin{tabular}{|c|c|c|c|c|c|c|c|c|c|c|c|c|}
\hline \multirow[b]{2}{*}{$\begin{array}{l}\text { code } \\
\Lambda_{\mathrm{c}}\end{array}$} & \multirow[b]{2}{*}{ Landcover } & \multirow[b]{2}{*}{$\begin{array}{l}\mathrm{h} \\
\mathrm{m}\end{array}$} & \multicolumn{2}{|c|}{ Growing season } & \multicolumn{4}{|c|}{ LAI parameters } & \multicolumn{4}{|c|}{ BVOC parameters ${ }^{1}$} \\
\hline & & & $\begin{array}{r}\text { SGS50 } \\
\text { day }\end{array}$ & $\begin{array}{r}\text { EGS50 } \\
\text { day }\end{array}$ & $\begin{array}{l}\mathrm{LAI}_{\min } \\
\mathrm{m}^{2} \mathrm{~m}^{-2}\end{array}$ & $\begin{array}{l}\mathrm{LAI}_{\max } \\
\mathrm{m}^{2} \mathrm{~m}^{-2}\end{array}$ & $\begin{array}{r}L_{\mathrm{S}} \\
\text { days }\end{array}$ & $\begin{array}{r}L_{\mathrm{E}} \\
\text { days }\end{array}$ & $\begin{array}{r}D \\
\mathrm{gm}^{-2}\end{array}$ & $\begin{array}{r}\varepsilon_{\Lambda_{\mathrm{c}, \text { iso }}} \\
\mu \mathrm{gg}^{-1} \mathrm{~h}^{-1}\end{array}$ & $\begin{array}{r}\varepsilon_{\Lambda_{\mathrm{c}, \mathrm{mtl}}} \\
\mu \mathrm{gg}^{-1} \mathrm{~h}^{-1}\end{array}$ & $\begin{array}{r}\varepsilon_{\Lambda_{\mathrm{c}, \mathrm{mtp}}} \\
\mu \mathrm{gg}^{-1} \mathrm{~h}^{-1}\end{array}$ \\
\hline $\mathrm{CF}$ & $\mathrm{T} / \mathrm{B}$ conif & $20^{2}$ & 0 & 366 & 5 & 5 & 1 & 1 & 1000 & (1) & $(0.5)$ & (2) \\
\hline DF & T/B decid & $20^{2}$ & $100(1.5)$ & $307(-2.00)$ & 0 & 4 & 20 & 30 & 320 & (15) & (2) & (2) \\
\hline NF & Med. needle & 8 & 0 & 366 & 4 & 4 & 1 & 1 & 500 & (4) & $(0.2)$ & (4) \\
\hline $\mathrm{BF}$ & Med. broadleaf & 15 & 0 & 366 & 4 & 4 & 1 & 1 & 300 & $(0.1)$ & (10) & $(0.2)$ \\
\hline $\mathrm{MC}$ & Med. crop & 2 & $123(2.57)$ & $237(2.57)$ & 0 & 3 & 70 & 44 & 700 & 0.1 & 0.2 & 0.2 \\
\hline $\mathrm{RC}$ & Root crop & 1 & 130 & 250 & 0 & 4.2 & 35 & 65 & 700 & 0.1 & 0.2 & 0.2 \\
\hline SNL & Moorland & 0.5 & 0 & 366 & 2 & 3 & 192 & 96 & 200 & 5 & 0.5 & 0.5 \\
\hline GR & Grass & 0.3 & 0 & 366 & 2 & 3.5 & 140 & 135 & 400 & 0.1 & 0.5 & 0.5 \\
\hline MS & Med. scrub & 2 & 0 & 366 & 2.5 & 2.5 & 1 & 1 & 150 & 8 & 0.5 & 2 \\
\hline WE & Wetlands & 0.5 & 0 & 366 & na & na & na & na & 150 & 2 & 0.5 & 0.5 \\
\hline TU & Tundra & 0.5 & 0 & 366 & na & na & na & na & 200 & 5 & 0.5 & 0.5 \\
\hline $\mathrm{DE}$ & Desert & 0 & 0 & 366 & na & na & na & na & 0 & 0 & 0 & 0 \\
\hline ICE & Ice & 0 & 0 & 366 & na & na & na & na & 0 & 0 & 0 & 0 \\
\hline $\mathrm{U}$ & Urban & 10 & 0 & 366 & na & na & na & na & 50 & 0 & 0 & 0 \\
\hline IAM_CR ${ }^{3}$ & Generic crop & 1 & $123(2.57)$ & $213(2.57)$ & 3.5 & 3.5 & 0 & 0 & 0 & 0 & 0 & 0 \\
\hline IAM_DF ${ }^{3}$ & Generic DF & 20 & $105(1.5)$ & $297(-2)$ & 0 & 4 & 15 & 30 & 0 & 0 & 0 & 0 \\
\hline IAM_MF ${ }^{3}$ & Generic MF & 8 & 0 & 366 & 5 & 5 & 1 & 1 & 0 & 0 & 0 & 0 \\
\hline
\end{tabular}

Notes: conif $=$ coniferous; decid = deciduous; T/B = temperate/boreal; Med. = Mediterranean; For explanation of LAI parameters, see Sect. 5 and Fig. 4 ; SGS50, EGS50 are start and end of growing seasons (daynumber) at $50^{\circ} \mathrm{N}$. Values in parentheses give the rate of change (days) of SGS and EGS (e.g. d SGS/d latitude) with latitude. For example, SGS for DF occurs later at the rate of 1.5 days per degree latitude on moving north, or earlier when moving south; (na) - means not applicable. For these land-covers a bulk resistance formulation is used;

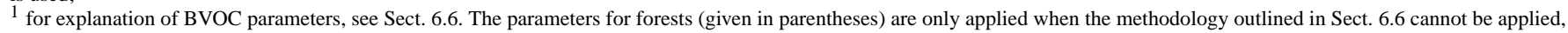
e.g. for non-European areas;

2 for boreal forests north of $60^{\circ} \mathrm{N}$, height is reduced by $5 \%$ per degree extra latitude, down to a minimum of $6 \mathrm{~m}$ for $74^{\circ} \mathrm{N}$ and above. LAI is reduced in the same proportion;

3 these land-cover categories are added as a tiny fraction of each vegetated grid, purely to collect information for provision to the vegetation-effects community and integrated assessment modelling.

For radiation calculations at level $k$ in the model, we need an estimate of the integrated cloud fraction in the column above and including $k$. We use a maximum overlap assumption, in which the fraction $f_{\text {cloud }}^{k}$ is set to the maximum value of the cell-volume cloud covers from $k$ and all layers above, i.e. from 1...k, cf. Fig. 2.

Following Pierce and Waldruff (1991) and Iqbal (1983), direct normal irradiance $\left(\mathrm{W} \mathrm{m}^{-2}\right)$ is then estimated as:

$I_{\mathrm{dir}}^{\mathrm{N}}=C_{\mathrm{N}} A T_{k} \exp \left(-B \sec (\theta) \frac{p}{p_{0}}\right)$

where $C_{\mathrm{N}}$ is a clearness number, assumed equal to $1, T_{k}$ is a transmissivity factor (set as $T_{k}=1-0.75 f_{\text {cloud }}^{3.4}$ ), $A, B$ are empirical co-efficients from Iqbal (1983), $\theta$ is the solar zenith angle, $p$ is the local pressure $(\mathrm{Pa})$ and $p_{0}$ is standard sea-level pressure, set equal to $101.3 \mathrm{kPa}$.

The direct and diffusive radiation on a horizontal surface $\left(\mathrm{W} \mathrm{m}^{-2}\right)$ are then given simply by:

$I_{\mathrm{dir}}=I_{\mathrm{dir}}^{\mathrm{N}} \cos \theta$

$I_{\text {diff }}=C I_{\text {dir }}$

where the co-efficient $C$ is also taken from Iqbal (1983).
Calculation of PAR values are made for each vegetated land-cover class within the grid, as PAR depends on the canopy's leaf area index (LAI). Following Norman (1979, 1982) we divide the canopy into sunlit and shaded leaves, and calculate the leaf-area and PAR for each class with:

$\mathrm{LAI}_{\text {sun }}=\left[1-\exp \left(-0.5 \frac{\mathrm{LAI}}{\cos \theta}\right)\right] \frac{\cos \theta}{\cos \alpha}$

$\mathrm{LAI}_{\text {shade }}=\mathrm{LAI}-\mathrm{LAI}_{\text {sun }}$

$$
\begin{aligned}
I_{\mathrm{PAR}}^{\text {shade }} & =I_{\text {diff }} \exp \left(-0.5 \mathrm{LAI}^{0.7}\right) \\
& +0.07 \quad I_{\text {dir }}(1.1-0.1 \mathrm{LAI}) \exp (-\cos \theta)
\end{aligned}
$$

$I_{\mathrm{PAR}}^{\mathrm{sun}}=I_{\mathrm{dir}} \cos \alpha / \cos \theta+I_{\mathrm{PAR}}^{\mathrm{shade}}$

where $\alpha$ is the average inclination of leaves in the canopy (assumed $60^{\circ}$ to represent a spherical leaf distribution).

\section{Land-cover}

Land-cover data are required in the model, primarily for dry deposition modelling and for estimation of biogenic 
emissions. As noted in Sect. 2, the standard EMEP grid has a resolution of approx. $50 \mathrm{~km} \times 50 \mathrm{~km}$, but grid sizes in reported applications have ranged from $5 \mathrm{~km} \times 5 \mathrm{~km}$ to $1^{\circ} \times 1^{\circ}$. Whatever the size, the land-use databases give the fractional coverage of different land-cover types within each surface grid cell. This allows sub-grid modelling using a socalled mosaic approach - allowing for example ecosystem specific deposition estimates.

The 16 basic land-cover classes are summarised in Table 3 . Additional land-use classes are easily defined and indeed the specific categories "IAM_DF", "IAM_MF" and "IAM_CR" are assigned for provision of data to ozone-effects studies and integrated assessment studies (e.g. Mills et al., 2011a,b). For European scale modelling the land-cover data are derived from the CORINE system and from the Stockholm Environment Institute at York (SEIY) system (www.york. ac.uk/http://www.sei-international.org/landcover). The basic principle used was to apply CORINE data wherever available, thereafter SEIY data. In addition, the more detailed SEIY data (especially on agriculture) was used to guide the split of the broader CORINE categories into the EMEP landclasses needed by the model. The final merge of these data was done at the the LRTAP Coordination Centre for Effects (CCE at RIVM, Posch et al. 2005). For global scale runs, land-cover from GLC-2000 (http://bioval.jrc.ec.europa. eu/products/glc2000/glc2000.php) are used.

For the vegetative land-cover categories for which stomatal modelling is undertaken (see Sect. 8.5), a number of phenological characteristics are needed. By default, these are specified in input tables for each EMEP land-cover $\Lambda_{c}$. In particular, the start and end of the growing season (SGS, EGS) must be specified. The development of leaf area index (LAI) within this growing season is modelled with a simple function as illustrated in Fig. 4. The parameter values used for these LAI estimates are given in Table 3.

\section{Emissions}

The standard emissions input required by EMEP model consists of gridded annual national emissions of sulphur dioxide $\left(\mathrm{SO}_{2}\right)$, nitrogen oxides $\left(\mathrm{NO}_{\mathrm{x}}=\mathrm{NO}+\mathrm{NO}_{2}\right)$, ammonia $\left(\mathrm{NH}_{3}\right)$, non-methane volatile organic compounds (NMVOC), carbon monoxide (CO), and particulates $\left(\mathrm{PM}_{2.5}\right.$, and $\mathrm{PM}_{c}$, the latter being the coarse aerosol fraction, $\mathrm{PM}_{10}-\mathrm{PM}_{2.5}$ ). The particulate matter categories can be further divided into elemental carbon, organic matter and other compounds as required. Emissions can be from anthropogenic sources (burning of fossil and biomass based fuels, solvent release, etc.), or from natural sources such as foliar VOC emissions or volcanoes. Several sources are hard to categorise as anthropogenic versus natural (Winiwarter et al., 1999), e.g. with emissions of $\mathrm{NO}$ from microbes in soils being promoted by $\mathrm{N}$-deposition and fertilizer usage.

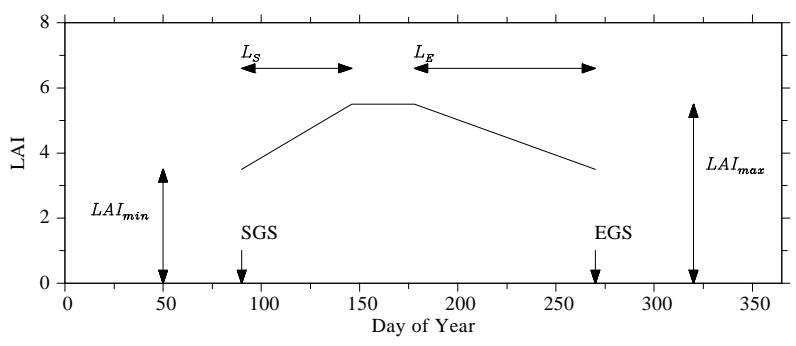

Fig. 4. Schematic of LAI development and associated parameters. SGS and EGS are the start and end of the growing season, in day-numbers. $L_{\mathrm{S}}$ and $L_{\mathrm{E}}$ represent the length of the LAI-increase and decline periods, also in day-numbers. Maximum and minimum (within the growing season) LAI values are given by $\mathrm{LAI}_{\max }$, $\mathrm{LAI}_{\min }$.

\subsection{National EMEP emissions}

As part of the EMEP Protocol under CLRTAP, national estimates of the anthropogenic emissions should be provided to EMEP every year from each country, along with spatial distribution to the EMEP grid. These emissions are provided for 10 anthropogenic source-sectors denoted by socalled SNAP codes. An eleventh source-sector exists in the officially-submitted database ("Other sources and sinks"), but this consists almost entirely of emissions from natural and biogenic sources. Officially submitted emissions from such sources are not used in the modelling work, except for those from volcanoes (sections 6.6-6.11 discuss the methods used for dealing with such emissions in the modelling framework). Further details of the anthropogenic emissions can be found in Mareckova et al. (2009); the emission database is available from http://www.emep.int, and further details can be obtained at that site.

Figure S1 in Supplement illustrates the spatial distribution of two sets of data for these anthropogenic emissions $\left(\mathrm{NO}_{\mathrm{x}}\right.$ and $\mathrm{SO}_{2}$ ), and two sets of data for biogenic VOC emissions.

\subsubsection{Vertical distribution}

These land-based gridded emissions are distributed vertically according to a default distribution based upon the SNAP codes, as shown in the Supplement, Table S3. These distributions were originally based upon plume-rise calculations performed for different types of emission source which are thought typical for different emission categories, under a range of stability conditions (Vidic, 2002), but have since been simplified and adjusted to reflect recent findings (Bieser et al., 2011; Pregger and Friedrich, 2009). The biggest change has been in sector 2 (non-industrial combustion), where now $100 \%$ of the emissions are placed in the lowest model layer, reflecting the large dominance of domestic combustion for this emission category. 


\subsubsection{Temporal distribution}

For most SNAP sectors, emissions are distributed temporally according to:

$f_{t}^{i, c}=f_{m, y}^{i, c} f_{d}^{i, c} f_{h}^{i}$

where $f_{t}^{i}$ is the temporal factor for SNAP sector $i$, country $c$, and $f_{m, y}^{i, c}, f_{d}^{i, c}, f_{h}^{i}$, are factors accounting for month (and year for SNAP-1, see below), day-of-week (or for SNAP-2 day of year, see below) and hour of the day. These factors are derived largely from data provided by the University of Stuttgart (IER) as part of the GENEMIS project (Friedrich and Reis, 2004), and are available as data files from the EMEP model website, www.emep.int. They are specific to each pollutant (except $f_{h}^{i}$ ), emission sector, and country, and thus reflect the very different climates and hence energy-use patterns in different parts of Europe. Fig. 5 illustrates the monthly variations in emissions of $\mathrm{SO}_{\mathrm{x}}, \mathrm{NO}_{\mathrm{x}}$ and $\mathrm{NMVOC}$ for selected countries in different parts of Europe. The annual cycles of $\mathrm{SO}_{\mathrm{x}}$ and $\mathrm{NO}_{\mathrm{x}}$ emissions for this year (2008) are rather constant in the Western European countries (Sweden, UK, Spain), but still show winter peaks in the two Eastern European countries (Poland, Ukraine). The ratio of $\mathrm{SO}_{\mathrm{x}}$ to $\mathrm{NO}_{\mathrm{x}}$ emissions varies markedly from country to country. Note that these plots illustrate total emissions, and the flat cycles for $\mathrm{SO}_{\mathrm{x}}$ and NOx may partly be ascribed to the importance of traffic emissions (which have very low seasonal cycles), and the lower winter/summer ratio assumed for SNAP1 in recent years (below). Emissions for particular sectors can show much stronger variation; an example for the domestic emissions of organic carbon emissions can be found in Bergström et al. (2012). The spatial distribution of BVOC emissions is presented in the Supplement, Fig. S1.

The three improvements which have been made to this methodology in 2011-2012 versions of the model are discussed below:

\section{SNAP-1: decreasing winter/summer ratios}

The temporal patterns from GENEMIS were derived for the year 1994, and prior to rv3.9 these values were used for all years, i.e. $f_{m}^{i, c}$ was the same set of 12 values for all years. However, as illustrated in Grennfelt and Hov (2005), the winter/summer ratios of electricity consumption have been decreasing in recent years, from about 1.33 in 1990 for the UK to 1.22 in 2000 , and from 1.1 to 1.02 over the same period in Italy. Despite very different climates, these changes both represent a $10 \%$ decrease in the winter/summer ratio over these 10 years. Discussion with IIASA (M. Amann personal communication, 2011) suggest that this decreasing trend has continued. For SNAP-1, power stations and suchlike, we therefore modify these variations, "flattening" the monthly factors towards the annual mean by a factor ranging from $0-10 \%$ between 1990 and 2010:

$f_{m, y}^{\mathrm{SNAP}-1, c}=f_{m, 1994}^{\mathrm{SNAP}-1, c}\left(1+\frac{\Delta(y)}{200} \cos \left(\frac{2 \pi(m-8)}{12}\right)\right)$

where $f_{m, 1994}$ is the monthly factor obtained from GENEMIS for 1994, $\Delta(y)$ is set to zero before 1990, $y-1990$ between 1990 and 2010, and to 1 after 2010. The cosine term provides an annual cycle, and $m-8$ ensures that maximum changes occur in February and August. (Note that the mean of all $f_{m, y}$ factors is 1.0 , we are just changing the amplitude of the annual cycle.)

\section{SNAP-2: use of degree-day factors}

SNAP-2 consists mainly of domestic combustion, and as of rv3.9, the day to day variation is based upon a modification of the heating degree day concept. For day of year $j$, with mean daily temperature in ${ }^{\circ} \mathrm{C}$ of $T_{j}^{24 h}$ we set the heating degree day to be $H_{d d, j}=\max \left(18-T_{j}^{24 h}, 1\right)$. (The minimum value of 1 is used rather than zero just to avoid numerical problems). These degree days are pre-calculated in the model for each grid cell, and averaged to find the annual mean degree-days for each grid-cell, $\overline{H_{d d}}$.

These degree-day factors are so far country-independent, being a function only of gridded daily temperatures. However, the GENEMIS monthly factors for SNAP-2 are used to establish a minimum 'base' factor for each country, $f_{B}^{c}$, which in some countries would include summertime use of gas-appliances for cooking, etc. Time-variation of emissions above this level are driven by calculations of heating degreedays. For day-number $j$, SNAP-2 we have:

$f_{j}^{2, c}=f_{B}^{c}+\left(1-f_{B}^{c}\right) H_{d d, j} / \overline{H_{d d}}$

Thus, in summertime where temperatures are close to or exceed $18^{\circ} \mathrm{C}$, this emission factor is very small, but in winter the factor is usually significant, and can change quite substantially from day to day.

\section{Hourly emissions}

Earlier versions (up to rv $4 \beta$ ) of the EMEP model used simple day-night factors (see Table S4) to allocate emissions within the day. In version rv4 we make use of new hourly data, provided by B. Bessagnet, INERIS, as part of ongoing work for the EMEP task Force on Measurements and Modelling. These data consist of a matrix of 11 SNAP sectors $\times 7$ days per week $\times 24 \mathrm{~h}$. These values are somewhat simplified versions of the hourly data presented by Menut et al. (2012).

\subsection{VOC speciation}

Speciation of VOC emissions is also specified separately for each source-sector. The EMEP model uses a "lumped- 
molecule" approach to VOC emissions and modelling, in which for example the model species n-butane represents all $\mathrm{C} 3+$ alkanes, and o-xylene represents all aromatic species (Andersson-Sköld and Simpson, 1997). As discussed in more detail in Hayman et al. (2012), the VOC data used in the current EMEP model are derived from the detailed United Kingdom speciation given in Passant (2002). Although the exact VOC speciation used can be varied to suit particular emission scenarios (e.g. Reis et al., 2000), the default split is typically used, as given in the Supplement, Table S5.

\subsection{PM speciation}

Where elemental and/or organic carbon (EC, OC) are required, emissions of $\mathrm{PM}_{2.5}$ and $\mathrm{PM}_{10}$ need to be speciated into these components. In fact, we are often interested in emissions of organic matter, OM, which includes for example oxygen, hydrogen and other atoms bound to the OC. In order to generate these speciations, we make use of country specific information on EC, OC and PM emissions provided by IIASA. For the fine PM fraction, OM emissions by mass are assumed to be 1.3 times the OC emission, although with a cap to make sure that $\mathrm{EC}+\mathrm{OM} \leq 0.99 \mathrm{PM}$. For the even more uncertain coarse fraction, we use a simple default speciation as given in the Supplement, Table S6.

For some studies, explicit emissions of EC (or related black carbon, BC) have been available, e.g. for the modelling studies within the CARBOSOL project (Fagerli et al., 2007; Simpson et al., 2007b; Tsyro et al., 2007) emissions from Kupiainen and Klimont (2007) were used, and for the EUCAARI project (Kulmala et al., 2011; Bergström et al., 2012) emissions were from van der Gon et al. (2009).

\subsection{Aircraft}

Emissions of $\mathrm{NO}_{\mathrm{x}}$ from aircraft are provided by data from the EU-Framework Programme 6 Integrated Project QUANTIFY. The data have been downloaded from the project website www.pa.op.dlr.de/quantify. The emissions are calculated on an annual basis and disaggregated according to a seasonal variation to create monthly files on a spatial resolution of $1^{\circ} \times 1^{\circ} \times 610 \mathrm{~m}$. The emissions are interpolated to the relevant model grid during model runtime. In the EMEP model, only $\mathrm{NO}_{\mathrm{x}}$ emissions from aircraft are used so far.

\subsection{Shipping}

The emissions from international shipping were created originally by ENTEC (now part of AMEC Environment Infrastructure, UK, www.amec-ukenvironment.com) and IIASA, and recently in the context of the revision of national emission ceilings directive as described in Cofala et al. (2007) and Jonson et al. (2009). The latest data take account of reduced sulphur emissions in recent years. Data are now available for $\mathrm{NO}_{\mathrm{x}}, \mathrm{SO}_{\mathrm{x}}$ and PM (for 2000, 2005, 2010, 2015, 2020, 2025 and 2030), with interpolation between these years when required.

Emissions from national shipping are not included in this ship inventory as national emissions should be included in the reported emissions (SNAP sector 8) to UN-ECE by the individual parties to LRTAP Convention. Unfortunately not all countries report emissions from national shipping, and for those who do it can not be distinguished from other mobile sources.

\subsection{Foliar NMVOC emissions}

Biogenic emissions of isoprene and (if required) monoterpenes are calculated in the model for every grid-cell, and at every model time-step, using near-surface air temperature $\left(T_{2}\right)$ and photosynthetically active radiation (PAR, see Sect. 4). Following the ideas proposed in Guenther et al. (1993, 1995), the first step in the emission processing is to define "standard" emission factors, which give the emissions of particular land-covers at standard environmental conditions $\left(30^{\circ} \mathrm{C}\right.$ and PAR of $\left.1000 \mu \mathrm{mol} \mathrm{m}^{-2} \mathrm{~s}^{-1}\right)$.

Emission factors for forests have been created from the the map of forest species generated by Köble and Seufert (2001). This work (also used by Karl et al. 2009 and Kesik et al. 2005) provided maps for 115 tree species in $30 \mathrm{Eu}-$ ropean countries, based upon a compilation of data from the ICP-forest network UN-ECE (1998). These data were further processed to the EMEP grid (S. Cinderby, SEIY, personal communication, 2004).

The EMEP model cannot deal with all these different forest species, but rather has maps of aggregated land-cover types, such as temperate/boreal coniferous forest (CF), as in Table 3. Emission rates for the EMEP aggregated landcover classes $\left(\Lambda_{\mathrm{c}}\right)$ are developed from maps of the Köble and Seufert (2001) land-cover types $\left(\lambda_{c}\right)$ with:

$E_{\Lambda_{\mathrm{c}, i}}^{*}=\frac{\sum_{\lambda_{\mathrm{c}}} \varepsilon_{\lambda_{\mathrm{c}, i}}^{*} A_{\lambda_{\mathrm{c}}} D_{\lambda_{\mathrm{c}}} \delta\left(\lambda_{\mathrm{c}} \in \Lambda_{\mathrm{c}}\right)}{\sum_{\lambda_{\mathrm{c}}} A_{\lambda_{\mathrm{c}}}}$

where $E_{\Lambda_{\mathrm{c}}, i}^{*}$ is the area-specific reference emission rate $\left(\mu \mathrm{g} \mathrm{m}^{-2} \mathrm{~h}^{-1}\right.$ ) for an EMEP land-cover class, at standard environmental conditions, $\varepsilon_{\lambda_{c, i}}^{*}$ is the mass-specific emission rate $\left(\mu \mathrm{g} \mathrm{g}^{-1}\right.$ (dry-weight) $\mathrm{h}^{-1}$ ) for BVOC compound $i$ and a particular real land-cover class $\left(\lambda_{\mathrm{c}}\right)$ at these standard conditions, $A_{\lambda_{\mathrm{c}}}$ is the area, and $D_{\lambda_{\mathrm{c}}}$ is the foliar biomass density of that species. The delta $(\delta)$ function is set to 1.0 for those species $\left(\lambda_{\mathrm{c}}\right)$ belonging to the EMEP land-cover group $\left(\Lambda_{\mathrm{c}}\right)$, zero otherwise. The standard emission factors are as given in the Supplement, Table S7.

For example, the standard emissions factor for the $\mathrm{CF}$ landcover (temperate/coniferous forest) would be calculated as the weighted sum of the species-specific emissions factors for any species included in this category, thus $\Lambda_{c}$ would include Norway spruce, Sitka spruce, Scots pine, etc. The 
Table 4. Summary of BVOC Environmental correction factors.

\begin{tabular}{|c|c|c|c|c|}
\hline $\begin{array}{l}\text { BVOC group } \\
\text { (i) }\end{array}$ & $\gamma_{\mathrm{L}}$ & $\gamma_{\mathrm{T}, i}$ & $\gamma_{\mathrm{CAN}, i}$ & Comment \\
\hline Isoprene & $\frac{\alpha C_{\mathrm{L} 1} Q}{\sqrt{1+\alpha^{2} Q^{2}}}$ & $\frac{\exp \frac{C_{\mathrm{T} 1}\left(T-T_{\mathrm{S}}\right)}{R T_{\mathrm{S}} T}}{1+\exp \frac{C_{\mathrm{T} 2}\left(T-T_{\mathrm{m}}\right)}{R T_{\mathrm{S}} T}}$ & 0.57 & $\gamma_{\mathrm{L}}$ and $\gamma_{\mathrm{T}, \text { iso }}$ as in Guenther et al. (1993) \\
\hline MTP & 1.0 & $\exp \left[\beta\left(T-T_{\mathrm{S}}\right)\right]$ & 1.0 & $\begin{array}{l}\text { Pool-dependent monoterpene emissions, } \gamma_{\mathrm{T}, \mathrm{MTP}} \text { from } \\
\text { Guenther et al. (1993) }\end{array}$ \\
\hline MTL & $=\gamma_{\mathrm{L}, \text { iso }}$ & $=\gamma_{\mathrm{T}, \mathrm{MTP}}$ & 0.57 & Light-dependent monoterpene emissions \\
\hline
\end{tabular}

resulting $E_{\Lambda_{\mathrm{c}, i}}^{*}$ give standard emission factors per $\mathrm{m}^{2}$ of the appropriate EMEP landcover category.

These $E_{\Lambda_{\mathrm{c}, i}}^{*}$ maps are intended to represent broad species characteristics rather than to capture details of the spatial distribution, and in order to reflect this we have smoothed the emission factor fields using a simple distance weighted filter.

For non-forest vegetation types (e.g. grasslands, seminatural vegetation) or for forest areas not covered by the emission factor maps described above (e.g. for eastern Russia, or non-European forests when modelling at global scale), default emission factors are applied. These factors are given in Table 3.

Emission potentials are then re-calculated to instantaneous emissions every time-step in the model (every $20 \mathrm{~min}$ ), using the grid-cell relevant temperature and radiation conditions:

$E_{\Lambda_{\mathrm{c}}, i}=E_{\Lambda_{\mathrm{c}}, i}^{*} \times A_{\Lambda_{\mathrm{c}}} \gamma_{\Lambda_{\mathrm{c}}, i}$

where $E_{\Lambda_{\mathrm{c}}, i}$ is the temperature and (where appropriate light) corrected emission per square meter of EMEP landcover $\Lambda_{c}$. The environmental correction factor $\gamma_{\Lambda_{\mathfrak{c}}, i}$ consists of corrections for the canopy LAI, temperature, light and canopyshading:

$\gamma_{\Lambda_{\mathrm{c}}, i}=\gamma_{\mathrm{LAI}} \gamma_{L} \gamma_{T, i} \gamma_{\mathrm{CAN}, i}$

where the LAI factor, $\gamma_{\text {LAI }}$ is simply defined as LAI/LAImax for each land-cover $\Lambda_{\mathrm{c}}$.

In the EMEP model, $\gamma_{\mathrm{CAN}, i}$ accounts for the effects of shading throughout the canopy. In principle a multi-layer canopy model could be used to specify leaf temperature and radiation conditions at different vertical levels. However, here we use a simple non-canopy approach, assuming that ambient temperature is similar to leaf temperature and that the use of "branch-level" emission potentials, which are typically a factor 1.75 smaller than leaf-level values (Guenther et al., 1994), accounts for the shading effect. Tests in European conditions have suggested differences in total emis- sions between the two methodologies of around $20 \%$ (Simpson et al., 1995). Given the many uncertainties introduced by the forest-canopy model itself (e.g. in temperature and light profiles within the canopy), and the lack of evaluation of such models under European conditions, we use the same procedure as Simpson et al. (1999) and simply specify that $\gamma_{\mathrm{CAN}, i}=$ $1 / 1.75=0.57$ for light-sensitive emissions and $\gamma_{\mathrm{CAN}, i}=1$ for the pool terpenes.

The light correction factor $\gamma_{\mathrm{L}}$ and temperature correction factor $\gamma_{\mathrm{T}}$ are different for the model's three emission categories: isoprene, pool-dependent monoterpenes (MTP) and light-dependent monoterpenes (MTL). Isoprene is always light and temperature controlled. MTP emissions are derived entirely from pool-emissions, and so have $\gamma_{\mathrm{L}}=1$ always. MTL emissions are synthesised, and are both light and temperate controlled. Table 4 summarizes the environmental correction factors used.

Figure 5 illustrates the monthly variations in emissions of isoprene and monoterpenes for selected countries in different parts of Europe, also in comparison to the anthropogenic emissions and soil-NO (below). These results clearly illustrate not just the strong seasonal cycle, but also the large country to country differences. In the UK for example, BVOC emissions are smaller than anthropogenic even in the summer months, but in the other countries summertime BVOC emissions can be far greater than anthropogenic NMVOC. Emissions of monoterpenes dominate over those of isoprene, also in most of the countries that are not shown. Annual emissions of these BVOC are given in Table S2 of the Supplement, where again the importance of these sources is obvious. The spatial distribution of isoprene and monoterpene emissions are shown in Fig. S1 of the Supplement. 

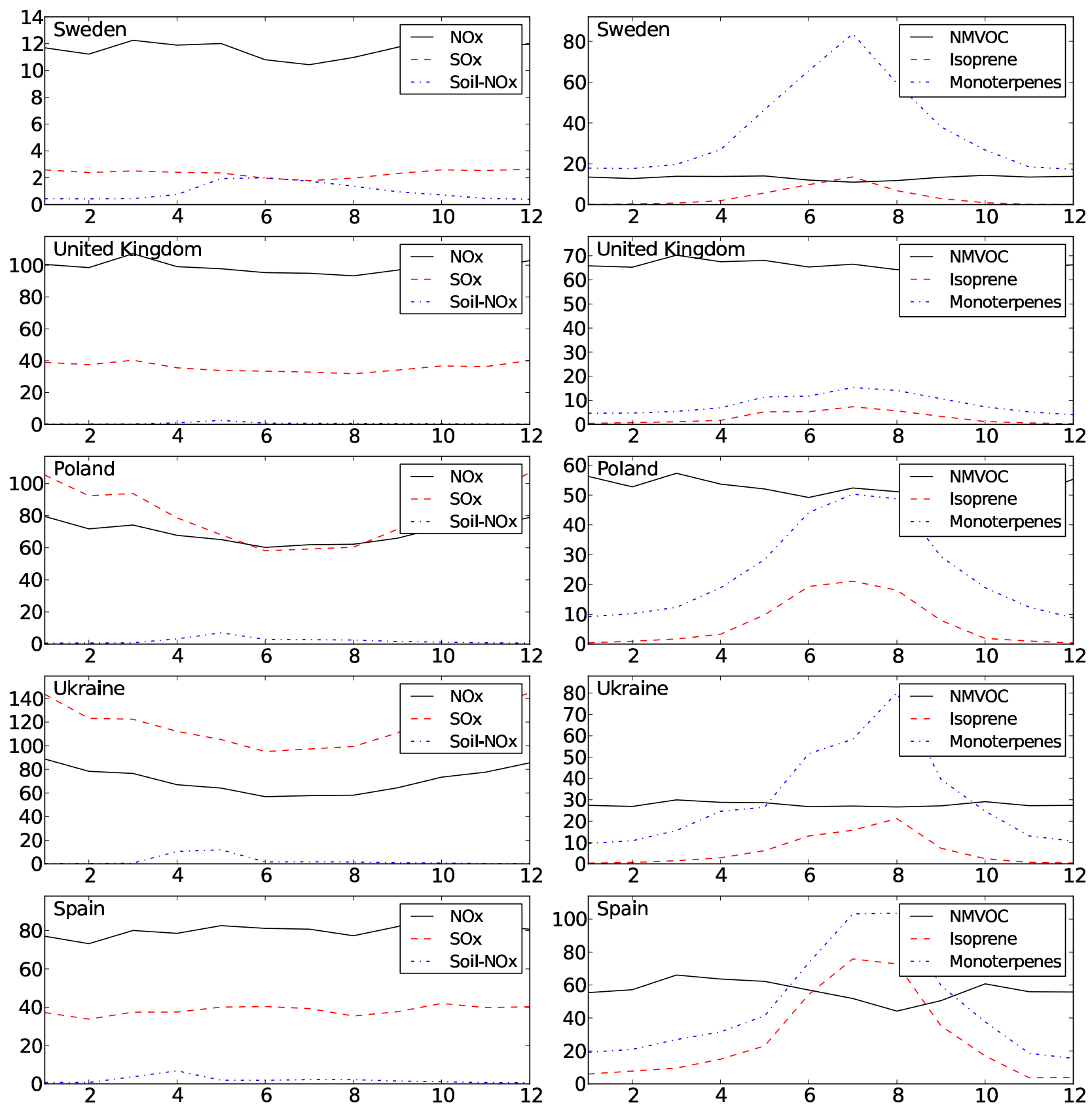

Fig. 5. Monthly emissions from selected countries. The left column gives combustion-derived $\mathrm{NO}_{\mathrm{x}}$ and $\mathrm{SO}_{\mathrm{x}}$, as well as soil-NO emissions. The right column gives anthropogenic NMVOC, and then biogenic isoprene and monoterpene emissions. Units are $\mathrm{Gg}_{\mathrm{month}}{ }^{-1}$, with emissions of $\mathrm{NO}_{\mathrm{x}}$ are as $\mathrm{NO}_{2}$, and $\mathrm{SO}_{\mathrm{x}}$ as $\mathrm{SO}_{2}$. and isoprene in the EMEP grid for the year 2006. Units: $\mathrm{mg} \mathrm{m}^{-2}$. 


\subsection{Soil NO emissions}

For global scale modelling the EMEP model can make use of monthly averaged soil NO emissions from a process-based terrestrial-biosphere model (Zaehle et al., 2011), kindly provided as netcdf files with $1^{\circ} \times 1^{\circ}$ resolution (S. Zaehle, personal communication, 2010).

For European-scale applications, we make use of more detailed land-cover and meteorological data. Emissions of NO from soils of seminatural ecosystems are specified as a function of the $\mathrm{N}$-deposition and temperature:

$E_{\mathrm{NO}, \Lambda_{\mathrm{c}}}=E_{\mathrm{NO}, \Lambda_{\mathrm{c}}}^{*} N_{\mathrm{T}} f_{N_{\mathrm{dep}}}$

where $E_{\mathrm{NO}, \Lambda_{\mathrm{c}}}^{*}$ is the maximum emission rate, set to $150 \mu \mathrm{g}(\mathrm{N}) \mathrm{m}^{-2} \mathrm{~h}^{-1}$ for coniferous forest, and $50 \mu \mathrm{g}(\mathrm{N}) \mathrm{m}^{-2} \mathrm{~h}^{-1}$ for deciduous forests and other seminatural ecosystems. $N_{\mathrm{T}}$ is the temperature response, identical to that used by Laville et al. (2005) and Linn and Doran (1984), and which also seems broadly consistent with data presented by Schaufler et al. (2010). $f_{N_{\text {dep }}}$ is a scaling factor to account for the $\mathrm{N}$-deposition load in each grid. For $f_{N_{\text {dep }}}$ we take the ratio of annual deposition divided by $5000 \mathrm{mg}(\mathrm{N}) \mathrm{m}^{-2}$, with maximum value 1.0.

For crops, emissions are given by:

$E_{\mathrm{NO}, \Lambda_{\mathrm{c}}}=E_{\mathrm{NO}}^{0}+E_{\mathrm{NO}, \Lambda_{\mathrm{c}}}^{*} N_{\mathrm{T}} f_{\beta, n_{\mathrm{d}}}$

where $E_{\mathrm{NO}, \Lambda_{\mathrm{c}}}^{*}$ is $80 \mu \mathrm{g}(\mathrm{N}) \mathrm{m}^{-2} \mathrm{~h}^{-1}$ for all crops, The function $f_{\beta, n_{\mathrm{d}}}$ applies a $\beta(2,2)$ function, which produces a value 1.0 when the daynumber $n_{\mathrm{d}}$ (between 1 to 366 ) is equal to the start of the growing season (SGS), falling to zero 30 days on either side of SGS. $E_{\mathrm{NO}}^{0}$ is the baseline emission level of $1 \mu \mathrm{g}(\mathrm{N}) \mathrm{m}^{-2} \mathrm{~h}^{-1}$.

The approaches used are meant to loosely capture two of the most important dependencies found in field and experimental studies. For example, from a detailed study of 15 forest sites across Europe, Pilegaard et al. (2005) found an almost linear relationship between $\mathrm{NO}$ emissions and $\mathrm{N}$ deposition at coniferous sites, with emissions ranging from non-detectable at a Finnish site to ca. $80 \mu \mathrm{g}(\mathrm{N}) \mathrm{m}^{-2} \mathrm{~h}^{-1}$ at two high-deposition sites in the Netherlands and Germany. For deciduous forests the relationship with N-deposition was much weaker, with rates varying from 0.7 (Scotland) to $13 \mu \mathrm{g}(\mathrm{N}) \mathrm{m}^{-2} \mathrm{~h}^{-1}$ (Germany). The deposition estimates were based upon throughfall for coniferous forest, and throughfall plus stem-flow for deciduous, and so are both uncertain and not strictly comparable. Schaufler et al. (2010) found a somewhat closer relationships between soils from coniferous and deciduous forests in an experimental study, albeit with only a few sites.

The procedure used for crops is designed to loosely mimic results shown in for example Butterbach-Bahl et al. (2009), Rolland et al. (2008, 2010), or Laville et al. (2005, 2009), all showing a broad peak in emissions in springtime (corre- sponding to the application of fertilizer and start of the growing season).

Figure 5 illustrates the monthly variations in emissions of soil-NO in comparison to the anthropogenic emissions of $\mathrm{NO}_{\mathrm{x}}$. The spring peak is clearly seen, starting earlier in southern compared to northern Europe. Country to country differences are large. For Sweden for example, a heavily forested country with relatively low population density, soil-NO emissions are rather large compared to the (low) anthropogenic emissions. For the densely populated United Kingdom, on the other hand, the soil-NO emissions are almost negligible compared to those from industry and traffic. Annual emissions of these soil-NO are given in Table S2 of the Supplement. It should be noted that, although relatively small in most countries (compared to the combustion-sources of $\mathrm{NO}_{\mathrm{x}}$ ), these emissions can still impact atmospheric chemistry because of their seasonal cycle and location in $\mathrm{NO}_{\mathrm{x}}{ }^{-}$ sensitive areas (Simpson et al., 2006a; Butterbach-Bahl et al., 2009).

This methodology has of course a number of weaknesses, including lack of controls by soil moisture, but the emission rates seem to correspond reasonably well to the (widelyscattered) published values from European forests and agricultural areas cited above. A more detailed methodology would require data on a host of factors which are not normally available at the European scale, including details of soil and vegetation types, and timing of crop growing seasons, fertilization, and irrigation.

\subsection{Sea salt}

The generation of sea salt aerosol over oceans is driven by the surface wind. There are two main mechanisms for sea salt aerosol generation: bubble bursting during whitecap formation (indirect) and through spume drops under the wave breaking (direct). The latter mechanism is believed to be important source for particles larger than $10 \mu \mathrm{m}$ and at wind speeds exceeding $10-12 \mathrm{~m} \mathrm{~s}^{-1}$. In the EMEP MSC-W model, sea salt calculations include primarily particles with ambient diameters up to $10 \mu \mathrm{m}$. These sea salt particles originate mainly from the bubble-mediated sea spray. As discussed in detail in Tsyro et al. (2011), the EMEP model's parameterisation scheme for calculating sea salt generation is based on two source functions, those of Monahan et al. (1986) and Mårtensson et al. (2003). The equations used are briefly recapitulated in the Supplement (Sect. S4.5), but the reader is referred to Tsyro et al. (2011) for a thorough discussion and comparison with measurements and other models.

\subsection{Forest and vegetation fires}

As of model version rv3.9 (November 2011), daily emissions from forest and vegetation fires are taken from the "Fire INventory from NCAR version 1.0" (FINNv1, Wiedinmyer et al. 2011). Data are available from 2005, with daily 
resolution, on a fine $1 \mathrm{~km} \times 1 \mathrm{~km}$ grid. We store these data on a slightly coarser grid $\left(0.2^{\circ} \times 0.2^{\circ}\right)$ globally for access by the EMEP model.

For earlier years, and in previous versions of the model (e.g. as used in Hodnebrog et al. 2012 or Tsyro et al. 2007), the model used the 8-daily fire emissions from GFED-2 (Global Forest Emission database, http://www. globalfiredata.org), as documented in van der Werf et al. (2010).

Emissions from either database include $\mathrm{SO}_{2}, \mathrm{CO}, \mathrm{NO}_{\mathrm{x}}$, NMHC, $\mathrm{PM}_{2.5}, \mathrm{PM}_{10}, \mathrm{OC}$, and $\mathrm{BC}$. Where $\mathrm{OM}$ is needed explicitly, we scale from OC using a factor of 1.7 (based on AMS measurements presented by Aiken et al. 2008). Emissions are homogeneously distributed over the eight lowest model layers, loosely following recommendations by Sofiev et al. (2009) to use a PBL height as an approximate height for emission injection.

\subsection{Dust}

The sources of natural mineral dust in the model include windblown dust from deserts, semi-arid areas, agricultural and bare lands within the model domain, as well as dust produced beyond the model grid (e.g. on African deserts) and transported to the calculation domain. A preliminary road-dust module has also been implemented. The inflow of African dust is accounted for through boundary conditions. The monthly average concentrations of fine and coarse dust, calculated with the global chemical transport model of the University of Oslo (CTM-2) for 2000, are currently used as boundary conditions (Grini et al., 2005).

The parameterisation of wind mobilisation of soil dust is based among others on the works of Marticorena and Bergametti (1995), Marticorena et al. (1997), Alfaro and Gomes (2001), Gomes et al. (2003), and Zender et al. (2003). The key parameter driving dust emissions is wind friction velocity. The dust mobilisation by wind and the horizontal motion of soil particles (called saltation) occurs when the wind friction velocity exceeds a threshold value. This threshold value depends on the size of soil aggregates. The model employs a partitioning scheme of wind shear stress between the erodible and non-erodible surface elements to calculate the threshold friction velocity (Marticorena and Bergametti, 1995). Currently, the threshold friction velocity is calculated for a particle size optimal for saltation, which is assumed to be $75 \mu \mathrm{m}$ (Zender et al., 2003). The general expression for threshold wind friction velocity $\left(u_{*, \text { th }}\right)$ is written as

$u_{*, \mathrm{th}}=\frac{u_{*, \mathrm{sm}}}{f_{\mathrm{eff}}} f_{w}$

where $u_{*, \mathrm{sm}}$ is the threshold friction velocity for erodible (smooth) part of surface, $f_{\text {eff }}$ is the efficient friction velocity ratio (describing wind drag partitioning between erodible surface and non-erodible roughness elements), and $f_{w}$ is the correction factor accounting for soil moisture. Following Marticorena and Bergametti (1995),

$f_{\text {eff }}=1-\left(\frac{\ln \left(\frac{z_{0}}{z_{0, \mathrm{~s}}}\right)}{\ln \left(0.35\left(\frac{10}{z_{0, \mathrm{~s}}}\right)^{0.8}\right)}\right)$

where $z_{0, \mathrm{~s}}$ is the roughness length of the erodible part of the surface (smooth), i.e. roughness of soil aggregates, $z_{0}$ is the roughness length of the non-erodible roughness elements (e.g. pebbles, rocks, vegetation). The roughness length of smooth erodible surfaces depends on soil morphology and is calculated following Marticorena et al. (1997) as $z_{0, \mathrm{~s}}=$ $d_{\mathrm{s}} / 30$, where $d_{\mathrm{s}}$ is the diameter of erodible particles, for which the median diameter of the most coarse population of the soil is used.

The suppression of soil erosion by soil moisture is accounted for as suggested by Fécan et al. (1998). The correction factor accounting for increase of threshold friction velocity due to soil moisture is calculated as

$f_{w}=1$

for $w \leq w^{\prime}$

$f_{w}=\sqrt{\left(1+121\left(w-w^{\prime}\right)^{0.68}\right)} \quad$ for $w>w^{\prime}$

where $w$ is the gravimetric soil moisture $\left(\mathrm{kg} \mathrm{kg}^{-1}\right)$ and $w^{\prime}$ is the minimum soil moisture from which the threshold velocity increases. The latter depends on soil texture as:

$w=0.14 F_{\text {clay }}^{2}+0.17 F_{\text {clay }}$

where $F_{\text {clay }}$ is the fractional clay content of the soil. In the present model version, $w^{\prime}$ is assumed to be equal to the Permanent Wilting Point (PWP) obtained from ECMWF-IFS data. The EMEP model's soil moisture index (Sect. 3.3) is converted first to volumetric, and then gravimetric soil water, following Zender et al. (2003), using information on sand content in the soil.

The land-use types, from which windblown dust emissions are calculated in the model, include deserts/bare lands and agricultural arable lands outside growing periods. Some additional constraints are imposed on the onset of windblown dust generation, so that no emissions take place: (1) during precipitation events (with precipitation rate greater than $0.2 \mathrm{~mm}$ per day) and two days afterwards; (2) under high surface relative humidity conditions ( $\mathrm{RH}>85 \%$ ); and (3) from frozen surface or surface covered by snow.

The condition for the onset of dust mobilisation by wind is $u_{*} \geq u_{*, \text { th }}$. The model allows a possibility of accounting for the gustiness of wind at free convection conditions. As proposed in Beljaars (1994), modified $10 \mathrm{~m}$ wind and wind 
friction velocity can then be calculated as:

$$
\begin{aligned}
& u_{10}=\sqrt{\left(V_{10}^{2}+\left(1.2 w_{*}^{2}\right)\right)} \\
& u_{*}=\frac{k}{\ln \left(\frac{z_{10}}{z_{0}}\right)} \sqrt{\left(u_{10}^{2}+\left(1.2 w_{*}\right)^{2}\right)}
\end{aligned}
$$

where $V_{10}$ is the velocity of horizontal wind at $10 \mathrm{~m}$ height, $w_{*}$ is the free convection velocity scale, $z_{0}$ is the land-use defined roughness length and $z_{10}=10 \mathrm{~m}$. The term $\left(1.2 w_{*}^{2}\right)$ represents the near surface wind induced by large eddies.

The horizontal flux of soil particles (i.e. saltation) is calculated as in Marticorena and Bergametti (1995)

$$
Q_{\mathrm{s}}=\frac{C \rho_{\mathrm{air}}}{g} u_{*}^{3}\left(1-\frac{u_{*, \mathrm{th}}}{u_{*}}\right)\left(1+\frac{u_{*, \mathrm{th}}}{u_{*}}\right)^{2}
$$

where $Q_{\mathrm{s}}$ is the horizontal mass flux of soil particles $\left(\mathrm{kg} \mathrm{m}^{-1} \mathrm{~s}^{-1}\right), \rho_{\text {air }}$ is the air density, $g$ is the gravitational acceleration and $C$ is the empirical coefficient $(C=2.61$ based on Zender et al. (2003) and references therein). The vertical flux of dust particles, released by sandblasting mechanism from the saltating and/or surface soil aggregates, is simulated as

$F=A_{\mathrm{s}} K \alpha Q_{\mathrm{s}}$

where $F$ is the vertical mass flux of dust $\left(\mathrm{kg} \mathrm{m}^{-2} \mathrm{~s}^{-1}\right), A_{\mathrm{S}}$ is the area fraction of erodible soil in the grid cell, $K$ is the coefficient accounting for soil erodibility (or availability of loose soil aggregates), and $\alpha$ is the sandblasting efficiency $\left(\mathrm{m}^{-1}\right)$. Based on the experimental results in Gomes et al. (2003), the following values (providing the best fit with measurements) are currently used in the model: $\alpha=2.0 \times 10^{-5}, 1.5 \times 10^{-5}$ and $1.0 \times 10^{-5} \mathrm{~m}^{-1}$ and $K=0.5,0.05$ and 0.02 for North African deserts, Mediterranean arid areas and arable lands respectively.

Finally, we can mention that a road dust emission module has been added to the EMEP model. The code and methodology are taken directly from that described in Denier van der Gon et al. (2010). This is very preliminary work, however, and details of the results will be presented elsewhere.

\subsection{Other sources}

Biogenic emissions of dimethly sulphide (DMS) can sometimes make a significant input to European sulphate levels. As discussed in detail by Tarrasón et al. (1995), the EMEP model uses a very simplified treatment, in which DMS is not modelled explicitly, but rather we assume that most DMS enters long-range transport already as sulphur dioxide. Monthly emission fields of DMS-derived $\mathrm{SO}_{2}$ are taken from the work of Tarrasón et al. (1995).

Emissions of volcanoes are introduced into the model as point sources, at a height determined by the height of each volcano. For the standard European-scale runs, volcano emissions are based upon officially reported data. These have been provided by Italy for many years, and recently by Iceland. For global and regional scale calculations, a new module for volcanic eruptions with default values based upon Mastin et al. (2009a,b) has recently been implemented and is currently in testing.

Emissions of $\mathrm{NO}_{\mathrm{x}}$ from lightning are included as monthly averages of global 3-D fields on a T21 $\left(5.65^{\circ} \times 5.65^{\circ}\right)$ resolution (Köhler et al., 1995).

\section{Chemistry}

The chemical scheme used for gas-phase chemistry traces its origins to the EMEP chemical mechanisms that began with Eliassen et al. (1982). This scheme has been updated and tested against other schemes in a number of studies (Simpson et al., 1993; Simpson, 1995; Kuhn et al., 1998; Andersson-Sköld and Simpson, 1999). The scheme documented in Simpson et al. (2003a) and Andersson-Sköld and Simpson (1999) is now denoted EmChem03. The latest scheme was largely developed in 2008-2009 and is denoted EmChem09. Compared to EmChem03, EmChem09 has updated rate-coefficients, and some additional species, including HONO. A detailed comparison of these chemical schemes, including their response to emission changes is presented in Hayman et al. (2012).

The EMEP model now uses a chemical pre-processor (GenChem) to convert lists of input chemical species and reactions to differential equations in Fortran code. At the time of writing, eight different chemical schemes have been tested within the EMEP model, as discussed in detail in Hayman et al. (2012) and summarised in Table 5. A large number of schemes for organic aerosol have also been tested (Simpson et al., 2007b; Bergström et al., 2012), but these are too complex and numerous to document here. Here we document only the default chemical scheme, EmChem09.

The numerical solution of the chemical equations is discussed in Sect. 7.8 and Supplement, Sect. S2.3.

\subsection{Species used, EmChem09}

Tables S8-S10 list the chemical compounds used in the EmChem09 scheme, along with associated characteristics such as the assignments used for dry and wet deposition. Most species are sufficiently long lived that they are included in both the advection and chemical equations. The species labelled "short-lived" have sufficiently short lifetimes that their concentrations are essentially controlled by local chemistry, so they are not included among the advected species. (Some short-lived species are advected anyway for numerical reasons.)

Note that this list excludes a number of intermediate species which are assumed to react immediately upon 
formation. For example, $\mathrm{H}$ atoms react immediately with $\mathrm{O}_{2}$ to form $\mathrm{HO}_{2}$, and so are not included explicitly.

The EMEP model distinguishes five classes of fine and coarse particles, which for dry-deposition purposes are assigned mass-median diameters $\left(D_{\mathrm{p}}\right)$, geometric standard deviations $\left(\sigma_{\mathrm{g}}\right)$, and densities $\left(\rho_{\mathrm{p}}\right)$. The characteristics of these aerosol classes are given in Table 6 .

It can be noted that the assumed $D_{\mathrm{p}}$ for coarse nitrate particles has been reduced in recent years compared to Simpson et al. (2003a) which had $D_{\mathrm{p}}=4 \mu \mathrm{m}$. This choice reflects an assumption that coarse nitrate formation is driven by surface-area rather than mass (hence favouring the smaller size-ranges), and consistent with Pakkanen et al. (1996) and Torseth et al. (2000). This assumption is very uncertain however, and probably depends on whether dust or sea-salt is the main reacting surface. In future we will consider explicit modelling of nitrate formation on different types of aerosol in order to better characterise the size-distribution. Accounting for the difference betweem MMD and aerodynamic diameter, the choice that $D_{\mathrm{p}}=3 \mu \mathrm{m}$ implies that $27 \%$ of calculated coarse-nitrate can be assigned to the $\mathrm{PM}_{2.5}$ fraction.

The semi-volatile organic compounds involved in SOA formation are a special case, in that the model transports both the gas and the aerosol fraction as one lumped concentration for numerical stability. The model also tracks the gas fraction as a separate quantity. For these compounds, dry and wet deposition processes are applied as appropriate to the different fractions.

\subsection{Gas-phase chemical mechanism}

Table S11 lists the chemical reaction mechanism used in the photo-oxidant model (for photolysis reactions, see below). Rate-coefficients for 3-body and some other reactions are given in Tables S12-S13. During 2008-2009 the scheme's rate-coefficients have been updated and in some cases replaced by Troe expressions to allow their application to the greater range of temperatures and pressures inherent in the 3-D model domain. The rates and products were updated to be, as far as possible, consistent with IUPAC recommendations (http://www.iupac-kinetic.ch.cam.ac.uk/); most of the reaction coefficients are from Atkinson et al. $(2004,2006)$.

\subsection{Photo-dissociation rates}

Table S14 lists the photolysis reactions used in the model for the EmChem09 mechanism. The reactions are taken from Simpson et al. (1993), with minor updates. The calculation of photo-dissociation rates (J-values) is identical to the methodology used for the earlier EMEP oxidant model (Jonson et al., 2001). J-values are calculated for clear sky conditions and for two predefined clouds using the PHODIS routine (Kylling et al., 1998). Ozone concentrations from a 2-D global model, extending from the surface to $50 \mathrm{~km}$ (Stordal et al., 1985) are scaled by observed total ozone columns from Dutsch (1974). Cloud base for both the predefined clouds is at $1 \mathrm{~km}$ above the ground. The first predefined cloud is $3 \mathrm{~km}$ deep, with a water content of $0.7 \mathrm{~g} \mathrm{~cm}^{-3}$ and a mean droplet radius of $10 \mu \mathrm{m}$. The second predefined cloud is $1 \mathrm{~km}$ deep, with water content of only $0.3 \mathrm{~g} \mathrm{~cm}^{-3}$ and a mean droplet radius of $10 \mu \mathrm{m}$. The J-values are calculated using the recommendations for absorption cross sections and quantum yields from DeMore et al. (1997). The introduction of different chemical mechanisms into the model with new species and photochemical reactions would, in principle, require the recalculation of these databases. As a temporary approach (prior to recalculation of the photolysis databases), we selected the existing photolysis process in the photolysis database which most closely matched the zenith angle dependence of the "new" photolysis process and derived factors to scale the rates. For example, the photolysis of $\mathrm{NO}_{2}$ provided an excellent description of the photolysis rate of the newly added species, HONO. This is described further in Hayman et al. (2012).

\subsection{Sulphate production}

The parameterization outlined below is previously described in Jonson et al. (2000) and Simpson et al. (2003a), with the only major change being the introduction of explicit $\mathrm{pH}$ calculations. In the model $\mathrm{SO}_{2}$ is oxidized to sulphate both in the gas phase and in the aqueous phase. We always assume equilibrium between gas and aqueous phase. It should be noted that in case the clouds occupy only a fraction of the grid volume, the total concentration (gas + aqueous) of soluble components are assumed to be uniformly distributed in the grid volume. If the cloud evaporates, ions formed in the cloud (e.g. sulphate) are simply assigned to the airborne phase.

For both gas and aqueous phase reactions we scale the reaction rates, rather than the concentrations, by the solubility and cloud volume fractions. In the present calculations we have assumed a constant value cloud liquid water content of $0.6 \mathrm{~g} \mathrm{~m}^{-3}$ (inside the clouds).

As of model version rv3.9, $\left[\mathrm{H}^{+}\right]$and $\mathrm{pH}$ in cloud water is estimated from the acid-base balance, including buffering by bicarbonate (through $\mathrm{CO}_{2}$ ):

$$
\begin{aligned}
{\left[\mathrm{H}^{+}\right]=} & 2\left[\mathrm{SO}_{4}^{2}-\right]+2\left[\mathrm{SO}_{3}^{2}-\right]+\left[\mathrm{HSO}_{3}^{-}\right]+\left[\mathrm{NO}_{3}^{-}\right] \\
& +\left[\mathrm{HCO}_{3}^{-}\right]-\left[\mathrm{NH}_{4}^{+}\right]
\end{aligned}
$$

This calculation is performed iteratively because the solubility or/and dissociation of $\mathrm{SO}_{2}$ and $\mathrm{NH}_{3}$ (and $\mathrm{CO}_{2}$ ) depend on $\mathrm{pH}$. (Prior to this version a constant $\mathrm{pH}$ of 4.3 was assumed). The effect of sea-salt and dust on the cloud $\mathrm{pH}$ is not taken into account. Although this could easily be implemented in the model code, large uncertainties are associated with especially the calculations of dust. In any case, studies over continents (and especially industrial/agricultural areas) 
Table 5. Chemical schemes available to the EMEP MSC-W model

\begin{tabular}{lccccl}
\hline Mechanism & Species & Reactions & $\begin{array}{c}\text { Photochemical } \\
\text { Reactions }\end{array}$ & $\begin{array}{c}\text { Emitted VOCs } \\
\text { (No. Biogenic) }\end{array}$ & Ref. \\
\hline CRI v2 & 465 & 1202 & 185 & $116(3)$ & Jenkin et al. (2008) \\
CRI v2 R5 & 195 & 569 & 96 & $3(3)$ & Watson et al. (2008) \\
CBM-IV & 38 & 95 & 13 & $10(1)$ & Gery et al. (1989) \\
CB-05 & 70 & 189 & 27 & $16(2)$ & Yarwood et al. (2005) \\
OSRM & 70 & 197 & 25 & $15(1)$ & Hayman et al. (2010) \\
EMEP-EmChem03 & 69 & 135 & & $10(1)$ & $\begin{array}{l}\text { Simpson et al. (2003a), } \\
\text { Andersson-Sköld and Simpson } \\
\end{array}$ \\
& & & & & (1999) \\
EMEP-EmChem09 & 72 & 137 & 26 & $10(1)$ & This work \\
EMEP-EmChem09soa & $\mathrm{b}$ & $\mathrm{b}$ & 26 & $11(2)$ & Bergström et al. (2012) \\
\hline
\end{tabular}

\footnotetext{
${ }^{a}$ We give here the number of species and reactions for the default EMEP chemistry where only isoprene is included for BVOCs. Some tracer species are also excluded. An $\alpha$-pinene chemistry is available for organic aerosol studies (Andersson-Sköld and Simpson, 2001; Simpson et al., 2007b), b the current SOA scheme also includes a large number of tracers that are not strictly necessary. Numbers of species in operational scheme should be known in February 2012. ${ }^{\mathrm{c}}$ The main SOA formulation is discussed in Bergström et al. (2012), but for this work the simplified 'NPAS' scheme which assumes non-volatile emissions is used, see Sect. 7.7.
}

Table 6. Characteristics of the aerosol classes used in the EMEP scheme. Table gives mass median diameter $\left(D_{\mathrm{p}}\right)$, geometric standard deviations $\left(\sigma_{\mathrm{g}}\right)$, densities $\left(\rho_{\mathrm{p}}\right)$, and enhancement factor $\left(F_{\mathrm{N}}\right)$, see Sect. 8.9

\begin{tabular}{ccccl}
\hline $\begin{array}{c}D_{\mathrm{p}} \\
\mu \mathrm{m}\end{array}$ & $\sigma_{\mathrm{g}}$ & $\begin{array}{c}\rho_{\mathrm{p}} \\
\mathrm{kg} \mathrm{m}^{-3}\end{array}$ & $F_{\mathrm{N}}$ & Species $^{\mathrm{a}}$ \\
\hline 0.33 & 1.8 & 1600 & 3 & fine-mode nitrate, ammonium \\
0.33 & 1.8 & 1600 & 1 & other fine-mode particles, eg sulphates, EC, OA \\
3.0 & 2.0 & 2200 & 1 & coarse nitrate \\
4.0 & 2.0 & 2200 & 1 & coarse sea-salt \\
4.5 & 2.2 & 2600 & 1 & coarse dust, sand \\
\hline
\end{tabular}

a The same classes are used with all schemes listed in Table 5;

$\mathrm{b}$ for semi-volatile compounds associated with organic aerosol (OA), these characteristics are applied to the particle fraction only.

show that over land cloud-water is dominated by sulphate and nitrate ions and ammonium and hydrogen cations (Aleksic et al., 2009; Aneja and Kim, 1993; Li and Aneja, 1992). The results suggested that the cloud water acidity may be coming predominantly from sulphate aerosol and less from nitric acid. Therefore we have chosen to omit sea salt and dust from the $\mathrm{pH}$ calculations.

Nitrate and sulphate aerosols and $\mathrm{HNO}_{3}$ are assumed to be completely dissolved. In the parameterization of aqueous phase chemistry we assume that Henry's law is fulfilled:

$\left[C_{(\mathrm{aq})}\right]=H_{\mathrm{c}} P_{\mathrm{c}}$

where $\left[C_{(\mathrm{aq})}\right]$ is the concentration of any soluble gas $C$ (mol $\left.1^{-1}\right)$ in the aqueous phase, $H_{\mathrm{c}}$ its Henry's law coefficient and $P_{\mathrm{c}}$ the partial pressure of $C$ in the gas phase. In the aqueous phase many soluble gases undergo rapid reversible reactions such as acid-base equilibrium reactions. For these gases it is convenient to define an efficient Henry's law coefficient where the total amount of dissolved gases is taken into ac- count. For example, the total amount of dissolved sulphur in solution (S(IV)) is equal to

$$
\left[\mathrm{S}(\mathrm{IV})_{(\mathrm{aq})}\right]=\left[\mathrm{SO}_{2(\mathrm{aq})}\right]+\left[\mathrm{HSO}_{3(\mathrm{aq})}^{-}\right]+\left[\mathrm{SO}_{3(\mathrm{aq})}^{2-}\right]
$$

The total dissolved $\mathrm{S}(\mathrm{IV})$ can be related to the partial pressure of $\mathrm{SO}_{2}$ over the solution $\left(P_{\mathrm{SO}_{2}}\right)$ by

$\left[\mathrm{S}(\mathrm{IV})_{(\mathrm{aq})}\right]=H_{\mathrm{SO}_{2}} P_{\mathrm{SO}_{2}}\left(1+\frac{K_{1}}{\left[\mathrm{H}^{+}\right]}+\frac{K_{1} K_{2}}{\left[\mathrm{H}^{+}\right]^{2}}\right)$

where $H_{\mathrm{SO}_{2}}$ is the Henry's law coefficient for $\mathrm{SO}_{2}$ and $K_{1}$ and $K_{2}$ are the first and second ionisation constants for sulphurous acid.

We define the effective Henry's law coefficient for $\mathrm{SO}_{2}$ as:

$H^{*}=\left[\mathrm{S}(\mathrm{IV})_{(\mathrm{aq})}\right] / P_{\mathrm{SO}_{2}}$

and make use of the ideal gas law $\left(P_{\mathrm{c}}=\left[C_{(\mathrm{g})}\right] \cdot R T\right.$, where $\left[C_{(\mathrm{g})}\right]$ is gas phase concentration of $C, R$ is the universal gas constant and $T$ is temperature) in order to find an expression for the total concentration $\left[C_{\mathrm{T}}\right]$ (gas + aqueous-phase) in a cloud volume:

$$
\begin{aligned}
{\left[C_{\mathrm{T}}\right] } & =\left[C_{(\mathrm{g})}\right] / \alpha+\left[C_{(\mathrm{aq})}\right] \\
& =\left[C_{(\mathrm{aq})}\right]\left(1+\frac{1}{H^{*} R T \alpha}\right)
\end{aligned}
$$

where $\alpha$ is the volume fraction of cloud water. Both $\left[C_{\mathrm{T}}\right]$ and $\left[\mathrm{C}_{(\mathrm{g})}\right]$ are in units $\mathrm{M}\left(\mathrm{mol}^{-1}\right)$. The fraction of the total (gas + aqueous) mass remaining in the interstitial cloud air $\left(f_{\mathrm{g}}\right)$ and 
the fraction absorbed by the droplets $\left(f_{\text {aq }}\right)$ can be calculated as:

$f_{\mathrm{aq}}=1-f_{\mathrm{g}}=\frac{\left[C_{(\mathrm{aq})}\right]}{\left[C_{\mathrm{T}}\right]}=\frac{1}{1+\left(H^{*} R T \alpha\right)^{-1}}$

In the model we use the local cloud fraction, defined in the meteorological input fields, as an approximate value for the fractional cloud volume. With the parameterisation above, $\mathrm{SO}_{2}$ is oxidized both in the cloud free parts of the grid box and in the interstitial cloud air.

\subsubsection{Gas phase}

In the gas phase $\mathrm{SO}_{2}$ is oxidized by a chain of reactions initiated by the reaction with $\mathrm{OH}$ :

$\mathrm{SO}_{2}+\mathrm{OH} \longrightarrow \ldots . . . \mathrm{H}_{2} \mathrm{SO}_{4} \quad\left(+\mathrm{HO}_{2}\right)$

with a reaction rate of $2.0 \times 10^{-12} \mathrm{~cm}^{3}$ molecule ${ }^{-1} \mathrm{~s}^{-1}$. Since some of the $\mathrm{SO}_{2}$ in a grid square is dissolved in clouds, we define a pseudo reaction rate to allow for this. Using $f_{\text {aq }}$ as defined above, then for a fractional cloud volume $W$, the fraction of $\mathrm{SO}_{2}$ in the gas-phase is given by:

$F_{\mathrm{g}}=1-f_{\text {aq }} W$

The pseudo-rate coefficient for model reaction $\mathrm{OH}+\mathrm{SO}_{2}$ $\rightarrow \mathrm{SO}_{4}+\mathrm{HO}_{2}$ then becomes $k_{\mathrm{cl}-\mathrm{OH}}=2.0 \times 10^{-12} F_{\mathrm{g}}(\mathrm{Ta}-$ ble S11).

\subsubsection{Aqueous phase}

Although a number of oxidants may contribute in the oxidation, only $\mathrm{O}_{3}, \mathrm{H}_{2} \mathrm{O}_{2}$ and $\mathrm{O}_{2}$ catalyzed by metal ions are considered here. The rate of production for sulphate in solution is expressed as:

$$
\begin{aligned}
d\left[\mathrm{SO}_{4}^{2-}\right] / \mathrm{d} t= & k_{\mathrm{cl} 11}\left[\mathrm{H}_{2} \mathrm{O}_{2}\right]\left[\mathrm{SO}_{2}\right] \\
& +\left(k_{\mathrm{cl} 2}\left[\mathrm{H}^{+}\right]\left[\mathrm{O}_{3}\right]+k_{c l 3}\right)\left(\left[\mathrm{SO}_{2}\right]+\left[\mathrm{HSO}_{3}^{-}\right]\right)
\end{aligned}
$$

where the reaction rate for the oxidation by $\mathrm{O}_{3}$ is $k_{\mathrm{cl} 2}=$ $1.8 \times 10^{4}\left[\mathrm{H}^{+}\right]^{-0.4} \mathrm{~mol}^{-1} 1$ (Möller, 1980) and the reaction rate for the oxidation by $\mathrm{H}_{2} \mathrm{O}_{2}$ is $k_{\mathrm{cl} 1}=8.3 \times 10^{5} \mathrm{~mol}^{-1} 1$ (Martin and Damschen, 1981). For the oxidation by $\mathrm{O}_{2}$ catalyzed by metal ions we assume a reaction rate of $k_{\mathrm{cl} 3}=$ $3.3 \times 10^{-10} \mathrm{~s}^{-1}$.

As for the gas phase production of sulphate, we define pseudo reaction rates, taking into account the solubility of $\mathrm{SO}_{2}, \mathrm{H}_{2} \mathrm{O}_{2}$ and $\mathrm{O}_{3}$ and the fractional cloud volume. The pseudo reaction rates then becomes:

$k_{\mathrm{cl} 1}^{\prime}=k_{\mathrm{cl} 1} \Gamma \frac{H_{\mathrm{SO}_{2}}}{H_{\mathrm{SO}_{2}}^{*}} f_{\mathrm{SO}_{2}} f_{\mathrm{H}} W$ $k_{\mathrm{cl} 2}^{\prime}=k_{\mathrm{cl} 2} \Gamma f_{\mathrm{SO}_{2}} f_{\mathrm{O}_{3}} W$

$k_{c l 3}^{\prime}=k_{c l 3} f_{\mathrm{SO}_{2}} W$

for the for oxidation by $\mathrm{H}_{2} \mathrm{O}_{2}, \mathrm{O}_{3}$ and $\mathrm{O}_{2}$, respectively. $f_{\mathrm{H}}$, $f_{\mathrm{SO}_{2}}$ and $f_{\mathrm{O}_{3}}$ are the fractional solubilities of $\mathrm{H}_{2} \mathrm{O}_{2}, \mathrm{SO}_{2}$ and $\mathrm{O}_{3}$ and $\Gamma$ is a conversion factor converting $k_{\mathrm{cl} 1}^{\prime}$ and $k_{\mathrm{c} 12}^{\prime}$ to molecules ${ }^{-1} \mathrm{~s}^{-1} \mathrm{~cm}^{3}$. $\mathrm{H}_{\mathrm{SO}_{2}}$ is the Henry's law constant for $\mathrm{SO}_{2}$ and $\mathrm{H}_{\mathrm{SO}_{2}}^{*}$ is the effective Henry's law constant for $\mathrm{S}(\mathrm{IV})$.

\subsection{Nitrate formation}

An important source of aerosol nitrate in the troposphere (and also of $\mathrm{NO}_{\mathrm{x}}$ loss) is the reaction of $\mathrm{N}_{2} \mathrm{O}_{5}$ on deliquescent aerosols, producing two $\mathrm{HNO}_{3}$ molecules:

$\mathrm{N}_{2} \mathrm{O}_{5(\mathrm{~g})}+\mathrm{H}_{2} \mathrm{O}_{(\mathrm{l})} \longrightarrow 2 \mathrm{HNO}_{3(\mathrm{aq})}$

$\mathrm{HNO}_{3}$ formed in the reaction above is initially assumed to evaporate and will take part in the formation of ammonium nitrate (Sect. 7.6) or coarse nitrate through reaction 'IN-19' (Supplement, Table S11). Mentel et al. (1999) showed that the uptake rate of $\mathrm{N}_{2} \mathrm{O}_{5}$ is around one magnitude lower for nitrate aerosols compared to sulphate aerosols, and this was the basis for the parameterisation of Riemer et al. (2003). More recent measurements in both the laboratory and ambient samples have shown very different values, however, with some studies revealing very low rates, and with very different dependencies, for example on the sulphate/organic ratio (e.g. Brown et al., 2009, 2006; Bertram et al., 2009; Bertram and Thornton, 2009; Riemer et al., 2009; Chang et al., 2011). Tests with updated schemes have so far not improved the performance of the model for particulate nitrate, and this aspect of the chemistry is probably one of the most uncertain. This reaction is applied whenever RH exceeds $40 \%$, and following Riemer et al. (2003) the rate we then use is:

$k_{\mathrm{N}_{2} \mathrm{O}_{5}}=\frac{1}{4} c_{\mathrm{N}_{2} \mathrm{O}_{5}} S \alpha_{\mathrm{N}_{2} \mathrm{O}_{5}}$

where $c_{\mathrm{N}_{2} \mathrm{O}_{5}}$ is the mean molecular speed for $\mathrm{N}_{2} \mathrm{O}_{5}$ and $S$ is here the available aerosol surface area, and $\alpha_{\mathrm{N}_{2} \mathrm{O}_{5}}$ is the reaction probability, which is weighted according to the composition of the aerosol:

$\alpha_{\mathrm{N}_{2} \mathrm{O}_{5}}=f \alpha_{1}+(1-f) \alpha_{2}$

with $\alpha_{1}=0.02, \alpha_{2}=0.002$, and

$f=\frac{m_{\mathrm{SO}_{4}^{2-}}}{m_{\mathrm{SO}_{4}^{2-}}+m_{\mathrm{NO}_{3}^{-}}}$ 
where $m_{\mathrm{SO}_{4}^{2-}}, m_{\mathrm{NO}_{3}^{-}}$are the aerosol mass concentrations of the secondary inorganic aerosols sulphate and nitrate. (Ideally we would use just fine nitrate here, but given the difficulties associated with such partitioning, we use the more robust sum of fine+coarse nitrate.)

The aerosol surface area, $S$, is calculated from secondary inorganic aerosol mass, $m_{\mathrm{SIA}}=m_{\mathrm{SO}_{4}^{2-}}+m_{\mathrm{NO}_{3}^{-}}+m_{\mathrm{NH}_{4}^{2+}}$, assuming an aerosol density of $\rho_{\text {aer }}$ to get volume $V$, then assuming a log normal size distribution, we get (e.g. Seinfeld and Pandis, 1998):

$S=\frac{3}{r_{\mathrm{g}}^{\mathrm{n}}} e^{-\frac{5}{2}\left(\ln \sigma_{\mathrm{g}}\right)^{2}} V$

where $r_{\mathrm{g}}^{\mathrm{n}}$ is the geometric number mean radius (assumed to be $0.068 \mu \mathrm{m}$ ), and $\sigma_{\mathrm{g}}=1.8$. The above formulations ignore two terms: (i) the effects of OM and other fine PM on aerosol surface area, which would increase the surface area and hence the rate (ii) inhibiting effect of OM on the sticking coefficient, which would reduce the rate (Riemer et al., 2009). Both terms are very uncertain, but opposite in sign.

For $\rho_{\text {aer }}$ we assume a specific aerosol density of $2 \mathrm{~g} \mathrm{~cm}^{-3}$ near $40 \% \mathrm{RH}$, appropriate for dry aerosol. At higher relative humidity, the salts undergo deliquescence, water content increases, and the density decreases towards values near $1 \mathrm{~g} \mathrm{~cm}^{-3}$. The particles grow by absorbing water and hence the surface available to heterogeneous reactions increases. To account in a simple way for the increased surface area, we apply

$\rho_{\mathrm{aer}}=\frac{2.5-1.25 R H}{100}, \mathrm{RH}>40$

where RH is given in \%.

\subsection{Gas/aerosol partitioning}

As of version rv3.9, the EMEP model uses the MARS equilibrium module of Binkowski and Shankar (1995) to calculate the partitioning between gas and fine-mode aerosol phase in the system of $\mathrm{SO}_{4}^{2+}-\mathrm{HNO}_{3}-\mathrm{NO}_{3}^{-}-\mathrm{NH}_{3}-\mathrm{NH}_{4}^{+}$. MARS has now replaced another code, EQSAM (Metzger et al., 2002; Metzger, 2000), which we have used previously. The MARS module also calculates the mass of aerosol water, see Sect. 11.4.

It should be noted that MARS does not treat sodium chloride and dust components, which is a weakness where seasalt (near coasts) and dust are important. Further, calculated PM water is expected to be underpredicted over seas and coast areas, where sea salt contributes considerably to PM. The effect of not accounting for mineral components is, however, anticipated to be smaller due to their smaller solubility compared to sea salt. It should be recognised that there are also significant uncertainties with other approaches, but in future we will likely replace MARS with a more comprehensive module. (See also Sect. 12.)

\subsection{Organic aerosol, SOA modelling}

As of 2011, a so-called volatility basis set (VBS) approach (Robinson et al., 2007; Donahue et al., 2009) for secondary organic aerosol (SOA) has been added to the available defaults of the EMEP chemical code. The new EmChem09soa scheme uses a variant of the VBS approach which is a somewhat simplified version of the mechanisms discussed in detail in Bergström et al. (2012).

The main differences to the schemes in Bergström et al. (2012) is that in EmChem09soa all primary organic aerosol (POA) emissions are treated as nonvolatile, to keep emission totals of both PM and VOC components the same as in the official emission inventories, while the semi-volatile ASOA and BSOA species are assumed to oxidise (age) in the atmosphere by $\mathrm{OH}$-reactions, leading to decreased volatilities for the SOA, and thereby increased partitioning to the particle phase. We denote this version of the EMEP VBS schemes the "NPAS" scheme (no partitioning of POA, aging of SOA). This assumption of non-volatility for POA is a simplification, but we believe a valid one for our purposes. This is discussed further in Sect. 12.

The OH-reaction rate for SOA-aging in this NPAS scheme is set to $4.0 \times 10^{-12} \mathrm{~cm}^{3}$ molecule ${ }^{-1} \mathrm{~s}^{-1}$ (as suggested by Lane et al. 2008) and each reaction leads to an order of magnitude decrease in volatility and a small increase in mass $(+7.5 \%)$ to account for oxygen-addition. This procedure is similar to that used for other EMEP VBS schemes; for further details see Bergström et al. (2012).

\subsection{Numerical solution of chemical scheme}

The chemical equations are solved using the TWOSTEP algorithm tested by Verwer et al. (1996) and Verwer and Simpson (1995). Technical details are discussed in the Supplement, Sect. S2.3.

\section{Dry deposition}

\subsection{Resistance formulation}

The dry deposition flux $\left(F_{\mathrm{g}}^{i}\right.$ ) of a gas $i$ to the ground surface is modelled using the so-called deposition velocity, $V_{\mathrm{g}}^{i}(z)$, such that:

$F_{\mathrm{g}}^{i}=-V_{g}^{i}(z) \chi^{i}(z)$

This equation is assumed to be true throughout the socalled constant flux layer. In the model we assume that the concentration and deposition velocity calculated at the centre of the lowest grid cell (typically $45 \mathrm{~m}$ ), a height we refer to below as the reference height $z_{\text {ref }}$, is within this layer. $V_{\mathrm{g}}^{i}(z)$ is calculated using a resistance approach:

$V_{\mathrm{g}}^{i}(z)=\frac{1}{R_{\mathrm{a}}(z)+R_{\mathrm{b}}^{i}+R_{\mathrm{c}}^{i}}$ 
where $R_{\mathrm{a}}$ is the aerodynamic resistance between the height $z$ and the top of the vegetation canopy (formally, $d+z_{0}$, where $d$ is the displacement height and $z_{0}$ the roughness length), $R_{\mathrm{b}}^{i}$ is the quasi-laminar layer resistance to gas $i$, and $R_{\mathrm{c}}^{i}$ is the surface (canopy) resistance.

Over grid-cells which are $100 \%$ sea we simply use the NWP model's meteorological parameters (and $z_{0}$ ) to calculate the resistances of Eq. (50). Where grid-cells contain other land-classes, we implement a so-called mosaic approach, whereby the the grid-average deposition rate is given by:

$\widetilde{V_{\mathrm{g}}^{i}}(z)=\sum_{k=1}^{N} f_{k} V_{\mathrm{g}, k}^{i}(z)$

where $\widetilde{Q}$ symbolises the grid-square average of any quantity $Q, f_{k}$ is the fraction of land-cover type $k$ in the grid-square, and $V_{\mathrm{g}, k}^{i}$ is the deposition velocity for this land-cover type, calculated with Eq. (50) using sub-grid (mosaic) values for each resistance term.

In order to make this sub-grid estimation, we are implicitly assuming that the height $z_{\text {ref }}$ can be treated as a so-called blending height (e.g. Mason, 1988; Claussen, 1995; Salzen et al., 1996), a height at which the concentrations and meteorological variables are representative of the properties of the full grid square, and not of the local underlying landcover. A further assumption is that the effects of the surface roughness layer can be ignored. Studies have shown that this approximation is probably fine for most purposes, but may impact the estimates of some metrics (AOT40, $\mathrm{POD}_{\mathrm{Y}}$, see Sect. 11) (Tuovinen and Simpson, 2008).

\subsection{Aerodynamic resistance, $R_{\mathrm{a}}$}

The first steps in the derivation of sub-grid $R_{\mathrm{a}}$ are to derive a grid-square average Obukhov length, $\widetilde{L}$, as in Eq. (8).

The 3-D model meteorology includes wind-speed $V_{\mathrm{H}}\left(z_{\text {ref }}\right)$ for the centre of the lowest grid level, at around $45 \mathrm{~m}$. We assume that this height is within or near the top of the surface layer, and proceed to calculate turbulence parameters based upon the local values of $z_{0}$ and $d$. These are simply derived from the height, $h$, of the vegetation for each land-cover type (Table 3). For forests we use $d=0.78 h, z_{0}=0.07 h$, following Jarvis et al. (1976), but with the restriction that $z_{0} \leq 1 \mathrm{~m}$. This restriction was found necessary when comparing modelled friction velocity $\left(u_{*}\right)$ with data from the Carbo-Europe network (Papale et al., 2006). For other vegetation, we use $d=0.7 h, z_{0}=0.1 h$. Over water, we use the Charnock relation with $z_{0}=m u_{*}^{2} / g$, setting the constant $m$ to be 0.0144 (Garratt, 1992). A minimum value of $z_{0}=1.5 \times 10^{-5} \mathrm{~m}$ is enforced, following Berge (1990). From the local $d$ and $z_{0}$, we then estimate a new $u_{*}$ based upon our reference height wind, $V_{\mathrm{H}}\left(z_{\text {ref }}\right)$ :

$u_{*}=\frac{V_{\mathrm{H}}\left(z_{\mathrm{ref}}\right) k}{\ln \left(\frac{z_{\mathrm{ref}}-d}{z_{0}}\right)-\Psi_{\mathrm{m}}\left(\frac{z_{\mathrm{ref}}-d}{L}\right)+\Psi_{\mathrm{m}}\left(\frac{z_{0}}{L}\right)}$ where $\Psi_{\mathrm{m}}$ is the standard integral function of the similarity profile of momentum (Garratt, 1992). Having calculated $u_{*}$ in this way, a local estimate of $L$ can be found by substituting $u_{*}$ in Eq. (8). The aerodynamic resistance for heat or scalars between any two levels $z_{1}$ and $z_{2}$ is calculated with the standard $R_{\mathrm{a}}(z)$ formula, the same as used in Eq. (50).

\subsection{Quasi-laminar layer resistance, $R^{i}{ }_{b}$}

The quasi-laminar layer resistance is calculated with

$R_{\mathrm{b}}^{i}=\frac{2}{k u_{*}}\left(\frac{S c_{i}}{P r}\right)^{2 / 3}$

where $S c_{i}$, the Schmidt number is equal to the $v / D_{i}$, with $v$ being the kinetic viscosity of air $\left(0.15 \mathrm{~cm}^{2} \mathrm{~s}^{-1}\right.$ at $\left.20^{\circ} \mathrm{C}\right)$ and $D_{i}$ is the molecular diffusivity of gas $i$, and $P r$ is the Prandtl number $(0.72)$. Over sea areas the expression of Hicks and Liss (1976) is used:

$R_{\mathrm{b}}^{i}=\frac{1}{k u_{*}} \cdot \ln \left(\frac{z_{0}}{D_{i}} k u_{*}\right)$

\subsection{Surface resistance, $R_{c}$}

Surface (or canopy) resistance is the most complex variable in the deposition model, as it depends heavily on surface characteristics and the chemical characteristics of the depositing gas. Our approach makes use of bulk canopy resistances and conductances ( $R$ and $G$ terms, where $G^{i}=1 / R^{i}$ for any gas $i$ ), and of unit-leaf-area (one-sided, projected) resistances and conductances, which we denote with lowercase letters $(r, g)$. The general formula for bulk canopy conductances, $G_{\mathrm{c}}$, is:

$G_{\mathrm{c}}=\mathrm{LAI} g_{\text {sto }}+G_{\mathrm{ns}}$

where LAI is the one-sided (projected) leaf-area index $\left(\mathrm{m}^{2}\right.$ $\mathrm{m}^{-2}$ ), $g_{\text {sto }}$ is the stomatal conductance, and $G_{\mathrm{ns}}$ is the bulk non-stomatal conductance. For non-vegetative surfaces only the last term is relevant.

The formulation for stomatal and non-stomatal conductances for most gases and conditions are dealt with in Sects. 8.5-8.6. Two special cases are (a) $\mathrm{HNO}_{3}$ and (b) $\mathrm{NH}_{3}$ over crops:

\section{(a) $\mathrm{R}_{\mathrm{c}}, \mathrm{HNO}_{3}$}

In normal conditions the surface resistance to $\mathrm{HNO}_{3}$ is effectively zero. A minimum value of $R_{\mathrm{c}}$ of $10 \mathrm{~s} \mathrm{~m}^{-1}$ is enforced for numerical reasons, so for $\mathrm{HNO}_{3}$ the whole canopy resistance is then simply given by:

$R_{\mathrm{c}}^{\mathrm{HNO}_{3}}=\max \left(10.0, R_{\text {low }}^{\mathrm{HNO}_{3}}\right)$

where $R_{\text {low }}^{\mathrm{HNO}_{3}}$ accounts for observations of $\mathrm{HNO}_{3}$ deposition over snow, and is set simply to $R_{\text {low }}^{\mathrm{HNO}_{3}}=-2 T_{\mathrm{S}}$, with $T_{\mathrm{S}}$ being the surface $(2 \mathrm{~m})$ temperature in ${ }^{\circ} \mathrm{C}$. These values loosely match those found by Johansson and Granat (1986) for temperatures of down to $-18^{\circ} \mathrm{C}$. 


\section{(b) $R_{\mathrm{c}}, \mathrm{NH}_{3}$, crops}

During the growing season for crop land-covers, the surface resistance is set very large, ensuring zero deposition. This procedure is designed to account for the fact that many croplands are actually emitters of $\mathrm{NH}_{3}$, rather than sinks (e.g. Sutton et al., 2000; Fowler et al., 2009, and references therein).

\subsection{Stomatal conductance, $g_{\text {sto }}$}

Stomatal conductance is calculated with a multiplicative model, a development of that described in Emberson et al. (2000a):

$g_{\text {sto }}=g_{\text {max }} f_{\text {phen }} f_{\text {light }} \max \left\{f_{\min }, f_{\mathrm{T}} f_{\mathrm{D}} f_{\mathrm{SW}}\right\}$

where $g_{\max }$ is the maximum stomatal conductance, and $f_{x}$ are factors (within 0-1) accounting for time of year (leaf phenology), the minimum observed stomatal conductance (min), light (actually PAR), temperature $(T)$, vapourpressure deficit $(D)$, and soil-water (SW). It should be noted that the canopy scale stomatal conductance (LAI $g_{\text {sto }}$ in Eq. 55) is a non-linear function of LAI, since $f_{\text {light }}$ and hence $g_{\text {sto }}$ are non-linear functions of LAI, see Supplement, Sect. S7.2.

The main new feature of the EMEP model with regard to this procedure is that soil water effects are now included by default. In Emberson et al. (2000a), $f_{\text {SW }}$ was based upon soil-water-potential (SWP). SWP is a very non-linear function of soil water content, varying with soil texture and homogeneity, and in practice can only be accurately estimated with in situ measurements. For these reasons $f_{\mathrm{SW}}$ was simply set to 1 in most previous EMEP model runs, i.e. stomatal uptake was not assumed to be limited by soil water availability (e.g. Simpson et al., 2007a). A number of techniques are being investigated with regard to soil water calculations (Büker et al., 2011), but as of version rv3.9 the EMEP code makes use of the simple $S_{\mathrm{MI}}$ index (Sect. 3.3) to calculate $f_{\text {SW. }}$. Rather than attempting to calculate absolute values of SWP, we use a simple procedure designed to capture the main effects of dry periods on $g_{\text {sto }}$ :

$$
\begin{aligned}
& f_{\mathrm{SW}}=1, \text { for } S_{\mathrm{MI}} \geq 0.5 \\
& f_{\mathrm{SW}}=2 S_{\mathrm{MI}} \text {, for } S_{\mathrm{MI}}<0.5
\end{aligned}
$$

For deposition modelling we use the $S_{\mathrm{MI}}$ values appropriate for deeper soil layers; for ECMWF inputs this is the top $1 \mathrm{~m}$ soil layer.

The methodology for $g_{\text {sto }}$ was developed and tested within a dry deposition framework for ozone, now referred to as the $\mathrm{DO}_{3} \mathrm{SE}$ (Deposition of Ozone and Stomatal Exchange) model (Emberson et al., 2000a,b, 2001, 2007; Klingberg et al., 2008; Simpson et al., 2001, 2003b; Tuovinen et al., 2001, 2004). Stomatal conductance calculated for any other gas $i$ is simply scaled from that for ozone using the ratio of the diffusivities in air of ozone and gas $i$. Table S18 in the Supplement gives the diffusivities (although expressed relative to water) used in the EMEP model.

Further details of the equations and current parameter values underlying the stomatal conductance algorithm are given in the Supplement, Sect. S7.2.

\subsection{Non-stomatal resistances}

$G_{\mathrm{ns}}$ is calculated specifically for $\mathrm{O}_{3}, \mathrm{SO}_{2}$, and $\mathrm{NH}_{3}$. Values for other gases are obtained by interpolation of the $\mathrm{O}_{3}$ and $\mathrm{SO}_{2}$ values (Sect. 8.8).

The ground-surface resistance, $R_{\mathrm{gs}}^{i}$, for a specific gas is an important component of the total non-stomatal resistance. Base-values of $R_{\mathrm{gs}}$ (denoted $\hat{R}_{\mathrm{gs}}$ ) for $\mathrm{O}_{3}$ or $\mathrm{SO}_{2}$ are given in Table S19. Similar to Zhang et al. (2003), these are modified for low temperature and snow cover with:

$$
\frac{1}{R_{\mathrm{gs}}^{x}}=\frac{1-2 f_{\text {snow }}}{F_{\mathrm{T}} \hat{R}_{\mathrm{gS}}^{x}}+\frac{2 f_{\text {snow }}}{R_{\text {snow }}^{x}}
$$

where $x$ represents either $\mathrm{O}_{3}$ or $\mathrm{SO}_{2}, f_{\text {snow }}$ reflects the snow coverage, and $F_{\mathrm{T}}$ is a low-temperature correction factor - see Sect. 8.7.1 for both terms.

\subsubsection{Ozone, $G_{\mathrm{ns}}^{\mathrm{O}_{3}}$}

Our formulation of the non-stomatal conductance for ozone builds upon the framework of Emberson et al. (2000a), which has been been extensively evaluated in a number of studies (Emberson et al., 2000a; Tuovinen et al., 2001, 2004):

$G_{\mathrm{ns}}^{\mathrm{O}_{3}}=\frac{\mathrm{SAI}}{r_{\mathrm{ext}}}+\frac{1}{R_{\mathrm{inc}}+R_{\mathrm{gs}}^{\mathrm{O}_{3}}}$

where SAI is a surface area index $\left(\mathrm{m}^{2} \mathrm{~m}^{-2}\right), r_{\text {ext }}$ is the external leaf-resistance (cuticles+other surfaces) per $\mathrm{m}^{2}$ PLA, $R_{\text {inc }}$ is the in-canopy resistance, and $R_{\mathrm{gs}}$ is the ground surface resistance (soil or other ground cover, e.g. moss). The external resistance $r_{\mathrm{ext}}$ is set to $2500 F_{\mathrm{T} \mathrm{sm}} \mathrm{s}^{-1}$, where $F_{\mathrm{T}}$ is a low-temperature correction factor (see Sect. 8.7.1). Following Erisman et al. (1994), the in-canopy resistance, $R_{\text {inc }}$, is defined as $b \mathrm{SAI} h / u_{*}$, where $h$ is the canopy height and $b=14 \mathrm{~s}^{-1}$ is an empirical constant.

SAI is simply set to LAI+1 for forests, or equal to LAI for non-crop vegetation. For crops a substantial part of the leaf area can be senescent. A simplified version of the methodology of Tuovinen et al. (2004), based upon the life-cycle of wheat, is applied:

$$
\begin{array}{r}
\mathrm{SAI}=\frac{5}{3.5} \mathrm{LAI} \text { for: } d_{\mathrm{SGS}}<d_{\mathrm{N}}<d_{\mathrm{SGS}}+L_{\mathrm{S}} \\
=\mathrm{LAI}+1.5 \text { for: } d_{\mathrm{SGS}}+L_{\mathrm{S}}<d_{\mathrm{N}}<d_{\mathrm{EGS}}
\end{array}
$$

where $d_{\mathrm{N}}$ is the day number, and $d_{\mathrm{SGS}}, d_{\mathrm{EGS}}$, and $L_{\mathrm{S}}$ are as defined in Sect. 5. Outside the growing season, $\mathrm{SAI}=\mathrm{LAI}=0$. 


\subsubsection{Ammonia, $G_{\mathrm{ns}}^{\mathrm{NH}_{3}}$}

For vegetated surfaces, the non-stomatal resistance $R_{\mathrm{ns}}$ for $\mathrm{NH}_{3}$ is assumed to depend upon surface ( $\left.2 \mathrm{~m}\right)$ temperature, $T_{\mathrm{S}}\left({ }^{\circ} \mathrm{C}\right)$, humidity levels, $\mathrm{RH}(\%)$, and on the molar "acidity ratio":

$a_{\mathrm{SN}}=\left[\mathrm{SO}_{2}\right] /\left[\mathrm{NH}_{3}\right]$

This acidity ratio is a first attempt to account for the observed changes in resistance in areas with different pollution climates (Erisman et al., 2001; Fowler and Erisman, 2003). More advanced treatments are possible, but the spread in values from different parameterisations is substantial (Massad et al., 2010).

The parameterisation of Smith et al. (2000) has been modified in order to take into account the effects of $a_{\mathrm{SN}}$, based upon an approach suggested by Smith et al. (2003). The resulting scheme can be expressed as:

$$
\begin{array}{rlrl}
\mathrm{R}_{\mathrm{ns}}^{\mathrm{NH}_{3}}= & \beta F_{1}\left(T_{2}, \mathrm{RH}\right) F_{2}\left(a_{\mathrm{SN}}\right) & & \\
& 100 & & \left(\text { for } T_{2}>0\right) \\
& 500 & \left(-5<T_{2} \leq 0\right) \\
& & \left(T_{2} \leq-5\right) \\
F_{1} \quad= & 10 \log _{10}\left(T_{2}+2\right) e^{\frac{100-\mathrm{RH}}{7}} & \\
F_{2}= & 10^{\left(-1.1099 a_{\mathrm{SN}}+1.6769\right)} &
\end{array}
$$

where $\beta$ is a normalising factor $(1 / 22=0.0455)$. The $F_{1}$ term is identical to that of Smith et al. (2000) and provides a relationship of $R_{\mathrm{ns}}$ with temperature and relative humidity. The second function, $F_{2}$, is an equation derived from observations presented in Nemitz et al. (2001), and relates the value at $95 \%$ relative humidity and $10^{\circ} \mathrm{C}$ to the molar ratio of $\mathrm{SO}_{2} / \mathrm{NH}_{3}$. The two terms are equal for molar $\mathrm{SO}_{2} / \mathrm{NH}_{3}$ ratio 0.3 . The factor $\beta$ is introduced in order to normalize one equation to the other, i.e. to ensure that the combined parameterisation is equal to the two separate terms for $95 \%$ relative humidity, $10^{\circ} \mathrm{C}$ and molar ratio 0.3 .

For above-zero temperatures $\mathrm{R}_{\mathrm{ns}}^{\mathrm{NH}_{3}}$ is constrained to lie between 10 and $200 \mathrm{~s} \mathrm{~m}^{-1}$. Finally, we do not distinguish wet or dry surfaces in this formulation (they are included in the RH dependency used above).

\subsection{Sulphur dioxide, $G_{\mathrm{ns}}^{\mathrm{SO}_{2}}$}

The canopy conductance of $\mathrm{SO}_{2}$ is strongly controlled by wetness and $\mathrm{NH}_{3}$ levels, as well as deposition of other acidic gases $\left(\mathrm{HNO}_{3}\right.$ and $\left.\mathrm{HCl}\right)$, adsorption of $\mathrm{CO}_{2}$, aerosol dry deposition, the composition of rain during precipitation events, ion leaching from the plants and processes such as dew fall and guttation (e.g. Flechard et al., 1999; Fowler et al., 2001, 2009; Burkhardt et al., 2009).

In order to develop a simple parametrisation for $G_{\mathrm{ns}}^{\mathrm{SO}_{2}}$, which nevertheless captured the main processes, Fagerli et al.
(2012) used long-term simultaneous measurements of $\mathrm{NH}_{3}$ and $\mathrm{SO}_{2}$ exchange, made within the EU LIFE Deposition Monitoring Project (Erisman et al., 2001), to derive operational parameterisations of co-deposition effects.

The parameterisation developed links the non-stomatal canopy uptake resistance of $\mathrm{SO}_{2}\left(\mathrm{R}_{\mathrm{ns}}^{\mathrm{SO}_{2}}\right)$ to the mean molar $\mathrm{SO}_{2} / \mathrm{NH}_{3}$ ratio in air over the last $24 \mathrm{~h}, a_{\mathrm{SN}}^{24 \mathrm{~h}}$ :

$$
\begin{array}{cl}
\mathrm{R}_{\mathrm{nS}}^{\mathrm{SO}_{2}}=11.84 \times e^{\left(1.1 \times a_{\mathrm{SN}}^{24 \mathrm{~h}}\right)} \times f_{\mathrm{RH}}^{-1.67} & \\
& \left(T_{2}>0\right) \\
& \\
100 & \left(-5<T_{2} \leq 0\right) \\
500 & \left(T_{2} \leq-5\right)
\end{array}
$$

For above-zero temperatures $\mathrm{R}_{\mathrm{ns}}^{\mathrm{SO}_{2}}$ is constrained to lie between 10 and $1000 \mathrm{~s} \mathrm{~m}^{-1} \cdot a_{\mathrm{SN}}^{24 \mathrm{~h}}$ is constrained to be maximum 3 , which corresponds to $\mathrm{R}_{\mathrm{ns}}^{\mathrm{SO}_{2}}=400 \mathrm{sm}^{-1}$ for $\mathrm{RH}$ of about $85 \%$. For non-vegetative surfaces, $\mathrm{R}_{\mathrm{ns}}^{\mathrm{SO}_{2}}$ is simply set to the base-values, $\hat{R}_{\mathrm{gs}}$, shown in the Supplement, Table S19.

\subsubsection{Snow and low-temperature corrections}

At temperatures below $-1{ }^{\circ} \mathrm{C}$, non-stomatal resistances are increased using a factor $F_{\mathrm{T}}$ as in Zhang et al. (2003):

$F_{\mathrm{T}}=e^{-0.2\left(1+T_{\mathrm{s}}\right)}$

with the constraint $1 \leq F_{\mathrm{T}} \leq 2$.

Resistances for $\mathrm{SO}_{2}$ over snow covered surfaces depend on the temperature. For instance, Granat and Johansson (1983) found that $\mathrm{SO}_{2}$ dry deposition velocities were smaller than $0.1 \mathrm{~cm} \mathrm{~s}^{-1}$ at temperatures below $-1^{\circ} \mathrm{C}$, but higher at warmer temperatures due to the presence of liquid water at the snow surface. $R_{\text {snow }}$ for $\mathrm{SO}_{2}$ (in $\mathrm{sm}^{-1}$ ) are here loosely based on Erisman et al. (1994) and Zhang et al. (2003):

$$
\begin{array}{rlr}
\mathrm{R}_{\text {snow }}^{\mathrm{SO}_{2}} & =70 & T_{\mathrm{s}} \geq+1{ }^{\circ} \mathrm{C} \\
=70 & \times\left(2-T_{2}\right)-1 \geq T_{\mathrm{S}}<1{ }^{\circ} \mathrm{C} \\
= & 700 & T_{\mathrm{s}}<-1^{\circ} \mathrm{C}
\end{array}
$$

For ozone, we simply set $\mathrm{R}_{\text {snow }}^{\mathrm{O}_{3}}=2000 \mathrm{sm}^{-1}$.

The term $f_{\text {snow }}$ in Eq. (59) is an estimate of the fractional cover of snow, derived from the NWP model's snow depth $\left(S_{\mathrm{d}}\right)$ and an assumed maximum value $S_{\mathrm{d}, \max }$ at which the snow fraction for canopy leaves is assumed to be 1 . We use a similar methodology to that proposed by Zhang et al. (2003):

$f_{\text {snow }}=\frac{S_{\mathrm{d}}}{S_{\mathrm{d}, \max }}$

with the constraint $0 \leq f_{\text {snow }} \leq 1$.

Zhang et al. (2003) presented tabulated values of $S_{\mathrm{d}, \max }$, but we simply assume that $S_{\mathrm{d}, \max }=0.1 h$, where $h$ is the 
height of the vegetation. If some fraction of the grid is covered with ice, we assume that $f_{\text {snow }}$ is the maximum value of the snow or ice fractions.

\subsection{Extension to other gases}

For all gases other than $\mathrm{HNO}_{3}$ or $\mathrm{NH}_{3}$ we obtain $G_{\mathrm{ns}}$ by interpolating between the values for $\mathrm{O}_{3}$ and $\mathrm{SO}_{2}$. This interpolation borrows the solubility index, here denoted $H_{*}$, and the reactivity index, $f_{0}$, from the Wesely (1989) methodology, but these are applied directly now to total non-stomatal conductance rather than to individual resistances (Table S18). As there is so little data available on non-stomatal resistances, even for $\mathrm{O}_{3}$ and $\mathrm{SO}_{2}$, this simpler scaling seems acceptable. With these indices, the dry and wet conductance values for a gas $i$ are obtained from the values for ozone and $\mathrm{SO}_{2}$ using:

$G_{\mathrm{ns}}^{i}=10^{-5} H_{*}^{i} G_{\mathrm{ns}}^{\mathrm{SO}_{2}}+f_{0}^{i} G_{\mathrm{ns}}^{\mathrm{O}_{3}}$

\subsection{Aerosol dry deposition}

Although a range of theory-based models is available to describe aerosol deposition, they often predict features which conflict with measured deposition rates (Pryor et al., 2008b,a; Petroff et al., 2008a; Flechard et al., 2011). For example, methods based on the well-known formulations of Slinn (1982) predict low deposition velocities to forest canopies. Alternative formulae of Zhang et al. (2001) predict higher deposition velocities, but no effect of canopy density. Several studies show that ammonium-nitrate has higher deposition velocities than sulphates, as a result of the partitioning of $\mathrm{NH}_{4} \mathrm{NO}_{3}$ to the more rapidly depositing $\mathrm{HNO}_{3}$ and $\mathrm{NH}_{3}$ gases (e.g. Fowler et al., 2009; Wolff et al., 2010). Petroff et al. (2008a,b) have presented an extensive discussion of the issues surrounding chemically-inert particles, and presented calculations where deposition is affected by both particle size and canopy leaf area index. Loosely based upon these reviews, and results from various experimental studies, we have implemented a new but deliberately simple scheme for particles in low vegetation and forests in the EMEP model. The basic formulation follows the same pattern as many studies (Wesely et al., 1985; Lamaud et al., 1994; Gallagher et al., 1997; Nemitz et al., 2004), but modified by an enhancement factor, $F_{\mathrm{N}}$, for nitrogen compounds:

$$
\begin{array}{cc}
\frac{V_{\mathrm{ds}}}{u_{*}} & =a_{1} \quad, L \geq 0 \\
=a_{1} F_{\mathrm{N}}\left[1+\left(\frac{-a_{2}}{L}\right)^{2 / 3}\right], L & <0
\end{array}
$$

where $V_{\mathrm{ds}}$ is the surface deposition velocity (Petroff et al., $2008 \mathrm{a}$ ), and $F_{\mathrm{N}}=3$ for fine-nitrate and ammonium, and 1 for all other compounds (Table 6). Further, we restrict application of the equation to $1 / L>-0.04 \mathrm{~m}^{-1}$. For all landcover categories except forests we use use $a_{1}=0.002$ from Wesely et al. (1985), and set $a_{2}$ to $300 \mathrm{~m}$, the simplified stability correction suggested by Gallagher et al. (1997).
For forests, we implement a simple dependence on surface area index:

$a_{1}=0.008 \frac{\mathrm{SAI}}{10}$

with $a_{2}$ again set to $300 \mathrm{~m}$, and the additional restriction that $a_{1} \geq 0.002$.

These values are loosely based upon the results of an analysis of measurements, and sets of complex calculations presented in Petroff et al. (2008a,b). Petroff et al. (2008b) calculated that a forest with total LAI of 22 would have a surface deposition velocity of ca. $0.002-0.004 \mathrm{~m} \mathrm{~s}^{-1}$ at $u_{*}=$ $0.45 \mathrm{~m} \mathrm{~s}^{-1}$ for particles in the accumulation size range (see Fig. 15, Petroff et al. 2008b). Our $0.008 u_{*}$ gives $0.004 \mathrm{~m} \mathrm{~s}^{-1}$ for this same friction velocity. They also showed that a decrease in LAI of a factor of 2 would reduce $V_{\mathrm{ds}}$ by a factor 1.5-2. Further, Petroff et al. (2008b)'s calculations suggested that $V_{\mathrm{ds}}$ is approximately proportional to LAI for $D_{\mathrm{p}} \sim 0.5 \mu \mathrm{m}$. For the EMEP model we make use of our surface area index, SAI, which accounts for non-leafy surfaces, and which is simply derived as SAI $=\mathrm{LAI}+1$ for forests. Petroff started with a total LAI of 22, which is ca. LAI $=10$ (1-sided), or $\mathrm{SAI}=11$. Simplifying, we therefore scale with SAI/10. (The use of SAI rather than LAI also prevent wintertime deposition in deciduous forests going to zero). Finally, we enforce a minimum $V_{\mathrm{ds}}$ of $0.002 u *$, consistent with Wesely as $\mathrm{SAI} \rightarrow 0$.

As pointed out by Venkatram and Pleim (1999), the resistance analogy is not appropriate for particles. We have therefore implemented the mass-conservative equation:

$V_{\mathrm{d}}(z)=\frac{v_{\mathrm{s}}}{1-e^{-r(z) v_{\mathrm{s}}}}$

where $v_{\mathrm{s}}$ is settling velocity, $V_{\mathrm{d}}(z)$ is the deposition velocity at height $z$, and $r(z)$ is the sum of the aerodynamic resistance and inverse $V_{\mathrm{ds}}$.

As summarized in Sect. 6, the EMEP model distinguishes five classes of fine and coarse particles, which are presently assigned mass-median diameters, geometric standard deviations $\left(\sigma_{\mathrm{g}}\right)$, and densities $\left(\rho_{\mathrm{p}}\right)$.

Although the dry-deposition rates of fine (accumulationmode) particles are not size-dependent in the model, the overall dry deposition rate of larger particles is affected by $v_{\mathrm{s}}$, which is strongly size-dependent. To account for this, the $v_{\mathrm{s}}$ calculations are integrated over the aerosol sizes, assuming a log-normal particle size distribution. These polydisperse settling velocities of coarse particles are calculated, using Eqs. (A25-A32) from Binkowski and Shankar (1995).

This revised scheme (and the changes in assumed aerosol size), which we here denote the EMEP-12 particle deposition scheme, gives significantly different rates to those used previously, with higher rates for fine particles (especially for the nitrogen components), and lower rates for coarse nitrate (since the assumed particle size is smaller). In order to illustrate the net effect, and place these results in the context of 
a previous comparison, we have rerun the setup of Flechard et al. (2011), but adding the new EMEP-12 particle deposition scheme. In Flechard et al. (2011), four different deposition modules (including EMEP-03) were applied for $55 \mathrm{Eu}-$ ropean sites covering four land-cover categories: Forest $(\mathrm{F})$, Seminatural (SNL), grassland (G) and crops (C). This study also made the general assumption that $19 \%$ of nitrate is in the coarse mode at all sites. The sites were part of the EU NitroEurope study, monitoring monthly concentrations of the key reactive nitrogen $(\mathrm{Nr})$ species, with the intention to estimate dry-deposition using inferential techniques (Tang et al., 2009).

Figure 6 compares the estimated deposition rates for particulate nitrate from the 2003 and 2012 versions of the EMEP scheme, and three other models, CBED, CDRY and IDEM models (for references and descriptions of these other models, see Flechard et al. 2011). The EMEP-03 and EMEP-12 results are surprisingly similar for all land-cover categories except crops, where EMEP-12 gives higher rates. This similarity is partly coincidental, however, representing the balance between increased deposition rates for fine particles, and reduced rates for coarse particles. For example, over grassland the estimated $V_{g}$ for fine-nitrate increased by a factor of 5 on average (from $0.28 \mathrm{~mm} \mathrm{~s}^{-1}$ for EMEP-03 to 1.4 $\mathrm{mm} \mathrm{s}^{-1}$ for EMEP-12), but $V_{g}$ for coarse nitrate decreased by a factor of six (from 7.2 to $1.2 \mathrm{~mm} \mathrm{~s}^{-1}$ ). The larger change for crops seen in Fig. 6 reflects the more complicated changes in $R_{b}$ (with different equations used inside and outside the growing season) used in the EMEP-03 scheme. The changes from EMEP-03 to EMEP-12 are thus significant, but as also seen in Fig. 6, differences between all methods are very large. As noted in Flechard et al. (2011), this is unfortunate, but currently the experimental difficulties are too large to allow a reliable choice of scheme (e.g Fowler et al., 2009; Pryor et al., 2008b,a). The new EMEP particle deposition scheme has at least the advantages of simplicity of formulation, and results are broadly consistent with recent but more complex schemes, and recent flux measurements (Fowler et al., 2009; Petroff et al., 2008a,b; Wolff et al., 2010).

\section{Wet deposition}

Parameterisation of the wet deposition processes in the EMEP model includes both in-cloud and sub-cloud scavenging of gases and particles. The parameterization of the wet deposition is previously described in Berge and Jakobsen (1998).

\subsection{In-cloud scavenging}

The in-cloud scavenging $S_{\text {in }}$ of a soluble component of mixing ratio $\chi$ is given by the expression:

$S_{\text {in }}=-\chi \frac{W_{\text {in }} P}{h_{\mathrm{s}} \rho_{\mathrm{w}}}$

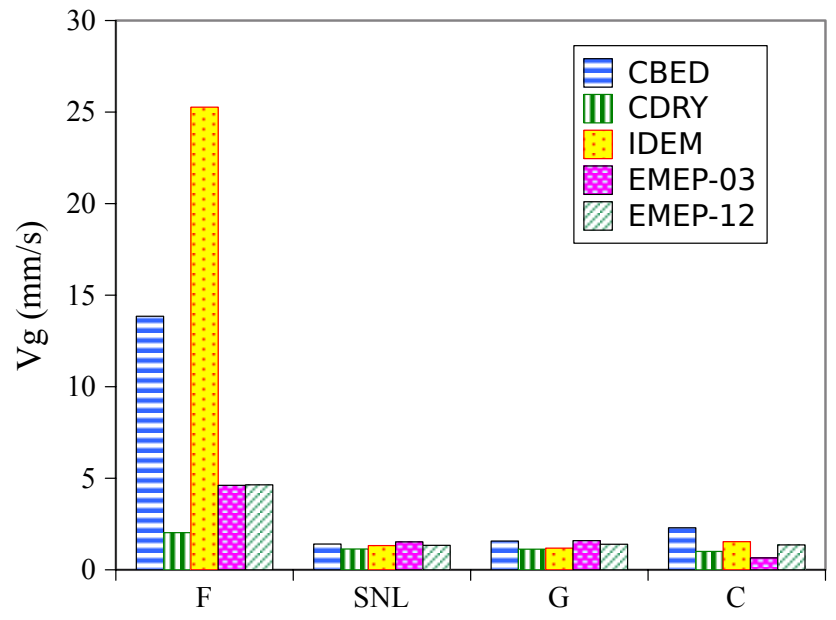

Fig. 6. Comparison of modelled deposition rates for particulate nitrate from the 2003 and 2012 versions of the EMEP model, and from the CBED, CDRY and IDEM models, evaluated over 55 European sites covering four land-cover categories: Forest (F), Seminatural (SNL), grassland (G) and crops (C). The setup is the same as that presented in Flechard et al. (2011), except that here we added the EMEP rv4 (EMEP-12) results for comparison.

where $W_{\text {in }}$ is the in-cloud scavenging ratio given in the Supplement, Table $\mathrm{S} 20, P\left(\mathrm{~kg} \mathrm{~m}^{-2} \mathrm{~s}^{-1}\right)$ is the precipitation rate, $h_{\mathrm{s}}$ is the characteristic scavenging depth (assumed to be $1000 \mathrm{~m})$ and $\rho_{\mathrm{w}}$ is the water density $\left(1000 \mathrm{~kg} \mathrm{~m}^{-3}\right)$. We do not account for the effect that dissolved material may be released if clouds or rain water evaporate.

\subsection{Below-cloud scavenging}

For below cloud scavenging a distinction is made between scavenging of particulate matter and gas phase components. The sub-cloud scavenging of the gases is calculated as:

$S_{\mathrm{sub}}^{\mathrm{gas}}=-\chi \frac{W_{\mathrm{sub}} P}{h_{\mathrm{s}} \rho_{\mathrm{w}}}$

where $W_{\text {sub }}$ is the sub-cloud scavenging ratio given in the Supplement, Table S20.

Wet deposition rates for particles are calculated, based on Scott (1979), as:

$S_{\mathrm{sub}}^{\mathrm{aer}}=-\chi \frac{A P}{V_{\mathrm{dr}}} \bar{E}$

where $V_{\mathrm{dr}}$ is the the raindrop fall speed $\left(V_{\mathrm{dr}}=5 \mathrm{~m} \mathrm{~s}^{-1}\right)$, $A=5.2 \mathrm{~m}^{3} \mathrm{~kg}^{-1} \mathrm{~s}^{-1}$ is the empirical coefficient (a MarshallPalmer size distribution is assumed for rain drops), and $\bar{E}$ is the size-dependent collection efficiency of aerosols by the raindrops (Table S20). The collection efficiency is size dependent, with a minimum for fine particles (see Laakso et al., 2003; Henzing et al., 2006). 


\section{Initial and boundary conditions}

Initial concentrations of major long-lived species are required in order to initialise model runs. Boundary conditions along the sides of the model domain and at the top of the domain are then required as the model is running. Additionally, we often need to specify concentrations of some species which are not explicitly included in the chemistry of interest, but that enter into reactions with some of the reacting chemical compounds ("background" species). We refer here to all of these types of data as initial and boundary conditions (IBCs). Two main methods of specifying boundary conditions are currently available:

1. Provision of 3-D fields for whole domain from previous runs of the same or another version of the EMEP model (self-assimilation), or from other models, typically global chemical transport models (CTMs).

2. Simple functions are used to prescribe concentrations in terms of latitude and time-of-year, or time-of-day. For ozone, 3-D fields for the whole domain are specified from climatological ozone-sonde data-sets, modified monthly against clean-air surface observations.

Method (1) allows great flexibility. A pre-processing program interpolates the data field of interest to the desired horizontal resolution (e.g. $50 \mathrm{~km} \times 50 \mathrm{~km}$ ), and to the 20 vertical levels in the EMEP model. The frequency of the update of the boundary conditions can be chosen freely, as long as the boundary condition field is provided for the same time period. Examples of this kind of approach can be found in Vieno et al. (2010), where the European scale model was used to provide IBCs for a $5 \mathrm{~km}$ scale model over the UK.

Method (2) is used for those species where rather simple descriptions of boundary condition are sufficient. Despite its simplicity, this method has the advantage that the IBCs are based upon measurements, ensuring a robustness which global CTM model results sometimes lack. For policy runs, the EMEP model is usually run using this methodology, and it is this method we document here.

\subsection{Ozone}

Ozone is the gas for which the specification of accurate boundary conditions is most essential to a good model performance. This is due to the fact that ambient ozone levels in Europe are typically not much greater than the Northern hemispheric background ozone. Boundary conditions of ozone are developed from a two-step procedure. First, the climatological $\mathrm{O}_{3}$ data of Logan (1998) is used, which provides gridded $\mathrm{O}_{3}$ data with resolution $4^{\circ}$ latitude by $5^{\circ}$ longitude for 13 pressure levels. These data are interpolated to the EMEP grid system to provide a monthly base-set for ozone IBCs.

These monthly data are then adjusted using a so-called "Mace-Head" adjustment. Mace Head is a site on the west coast of Ireland, ideally suited as a background site for midlatitude air masses. It was shown by Derwent et al. (1998), using trajectory analysis and other techniques, that the cleanair concentrations of $\mathrm{O}_{3}$ (and $\mathrm{CO}$ ) at Mace Head were basically uniform in a wide sector for air masses arriving from Iceland to Barbados - in other words, it confirmed the view of a general well-mixed background air mass.

For the EMEP model we have made use of an extended version of this analysis. Ozone concentrations from Mace Head have been sorted using sector-analysis, obtained using trajectories obtained from http://www.emep.int ${ }^{1}$. Monthly mean values of the ozone associated with easterly sectors (sectors 6-8) have been calculated. Where fewer than 15 days were available to make an average for a particular year, averages from a full 10-yr analysis were substituted for the missing days.

In order to generate an adjustment factor, the monthly values of observed $\mathrm{O}_{3}$ derived using this procedure, denoted $\mathrm{O}_{3}^{\mathrm{MH}}$, are compared with the average surface concentrations from the global datasets in the south-west quadrant of the EMEP domain, denoted $\mathrm{O}_{3}^{\mathrm{GD}}$. (Thus, if the coordinates of Mace Head are denoted $x_{\mathrm{M}}, y_{\mathrm{M}}, \mathrm{O}_{3}^{\mathrm{GD}}$ is the average concentration from model domain $x=1 . . x_{\mathrm{M}}, y=1 . . y_{\mathrm{M}}$ ). If the difference between the two datasets obtained in this way is $\Delta$ $\left(=\mathrm{O}_{3}^{\mathrm{MH}}-\mathrm{O}_{3}^{\mathrm{GD}}\right.$, in ppb), we simply add $\Delta$ to the ozone boundary conditions over the whole domain. Since the concentrations of ozone are generally increasing with height in the model domain (from say $40 \mathrm{ppb}$ to several hundred ppb), then the effect of this constant $\Delta$ term is greatest for the surface layer and quite small at say $5-10 \mathrm{~km}$ height.

Although simple, this procedure ensures that the BCs used for ozone are realistic in the mid-latitude region near ground level, at least near the Western boundary. Although based entirely upon one station, this correction has been found to result in good BCs for almost all sites on the west coast of Europe, ranging from Norway to Spain.

For other species where prescribed values are needed, simple functions have been chosen, designed to enable concentration values that correspond to observations. The concentrations are adjusted in the vertical and for latitude and time of the year (monthly fields) to match the observed distributions. Table S21 lists the parameters used, as described below.

We first calculate the seasonal changes in ground-level BC concentration, $\chi_{0}$, through:

$\chi_{0}=\chi_{\text {mean }}+\Delta \chi \cos \left(2 \pi \frac{d_{\mathrm{mm}}-d_{\mathrm{max}}}{n_{\mathrm{y}}}\right)$

where $\chi_{\text {mean }}$ is the annual mean near-surface concentration, $\Delta \chi$ the amplitude of the cycle, $n_{\mathrm{y}}$ is the number of days per year, $d_{\mathrm{mm}}$ is the day number of mid-month (assumed to be

\footnotetext{
${ }^{1}$ Prior to 1996 , sectors from another Irish site, Valentia, had to be used. However, results calculated after 1996 show almost identical sector-results, regardless of the choice of Mace Head or Valentia
} 
the 15 th), and $d_{\max }$ is day number at which $\chi_{0}$ maximises. Changes in the vertical are specified with a scale-height, $H_{z}$ :

$\chi_{\mathrm{IBC}}(z)=\chi_{0} \exp \left(-z / H_{z}\right)$

where $\chi_{\mathrm{IBC}}(h)$ is the concentration used for IBCs at height $z$. For simplicity we set $z$ to be the height of the centre of each model layer assuming a standard atmosphere. Values of $\chi_{\mathrm{IBC}}$ are constrained to be greater or equal to the minimum values, $\chi_{\min }^{\mathrm{v}}$, given in Table S21. For some species a latitude factor, given in Table S22, is also applied. Values of $\chi_{i}$ adjusted in this manner are constrained to be greater or equal to the minimum values, $\chi_{\min }^{h}$, given in Table S21.

Finally, for two species, we simply specify constant mixing ratios over the whole model domain, valid for 1990 (see Sect. 10.2 for other years). These are $1780 \mathrm{ppb}$ for methane and $600 \mathrm{ppb}$ for hydrogen.

\subsection{Trends in initial and boundary conditions}

The $\mathrm{BC}$ values discussed above are assumed appropriate for the year 1990. For other years these values are adjusted using trend factors. Such adjustments can be made with results of e.g. global CTMs (including EMEP model runs). Lacking other information we use the default trend factors as summarised in the Supplement, Table S23.

\section{Outputs}

The EMEP model produces a large number of outputs for a variety of purposes. Most are straightforward, for example maps of annual wet deposition of oxidised or reduced nitrogen. However, some outputs display special features or are provided for specific purposes. For example, one of the main reasons for running the EMEP model is to generate results for use in integrated assessment modelling (IAM), and for studies on the risks and damages caused by pollution, and a number of model outputs are designed with this in mind. Here we briefly describe some of the most important outputs.

\subsection{Near-surface concentrations}

The basic calculations of the EMEP CTM produce concentrations for model layers. The lowest layer is about $90 \mathrm{~m}$ deep, so concentrations from this layer may be interpreted as being applicable for $45 \mathrm{~m}$ above ground level (or stricter, above displacement height $d$ ). In order to estimate concentrations at heights more typical of measurements, typically around $3 \mathrm{~m}$ for EMEP observations, or at canopy top for some ozone-flux or AOT40 estimates, we make use of assumption that the vertical deposition flux density $\left(F_{\mathrm{g}}^{i}\right.$, Eq. 49) remains approximately constant within the atmospheric surface layer (e.g. Tuovinen, 2000). Referring to the model concentrations of species $i$ at reference height $z_{\text {ref }}$ of $45 \mathrm{~m}$ as $\chi^{i}\left(z_{\text {ref }}\right)$, we readily obtain the concentrations at any other height within the surface layer from Eq. (49):

$\chi^{i}(z)=\chi^{i}\left(z_{\mathrm{ref}}\right) \frac{V_{\mathrm{g}}^{i}\left(z_{\mathrm{ref}}\right)}{V_{\mathrm{g}}^{i}(z)}$

with appropriate calculations of the deposition velocity resistance terms as discussed in Sect. 8.

\subsection{Ecosystem-specific depositions}

As discussed in Sect. 8, the model's calculations of dry deposition are made separately for each sub-grid landcover. For provision to IAM or the effects community, these sub-grid estimates are aggregated to provide output deposition estimates for broader ecosystem categories, as shown in Table 7

A possible output would be deposition to water, but for IAM purposes the deposition of interest here is to the catchment area, rather than to the water surface. Thus, deposition estimates for waters are usually simply taken from the gridaverage depositions.

\subsection{Ozone statistics}

A number of statistics are typically used to describe the distribution of ozone within each grid square, and for input to IAM assessments:

Mean of Daily Max. Ozone. - First we evaluate the maximum modelled concentration for each day, then we take either 6-monthly (1 April-30 September) or annual averages of these values.

SOMO35. - The Sum of Ozone Means Over $35 \mathrm{ppb}$ is the indicator for health impact assessment recommended by WHO. It is defined as the yearly sum of the daily maximum of 8 -h running average over $35 \mathrm{ppb}$. For each day the maximum of the running 8 -h average for $\mathrm{O}_{3}$ is selected and the values over $35 \mathrm{ppb}$ are summed over the whole year.

If we let $A_{8}^{d}$ denote the maximum 8-hourly average ozone (in ppb) on day $d$, during a year with $N_{\mathrm{y}}$ days $\left(N_{\mathrm{y}}=365\right.$ or 366$)$, then SOMO35 can be defined as:

SOMO35 $=\sum_{d=1}^{d=N_{y}} \max \left(A_{8}^{d}-35,0\right)$

where the max function evaluates $\max (A-B, 0)$ to $A-B$ for $A>$ $B$, or zero if $A \leq B$, ensuring that only $A_{8}^{d}$ values exceeding $35 \mathrm{ppb}$ are included. The corresponding unit is ppb days.

$P O D_{Y}$. - (Formerly AFstY) - Phyto-toxic ozone dose, is the accumulated stomatal ozone flux over a threshold $Y$, i.e.:

$\operatorname{POD}_{Y}=\int \max \left(F_{\mathrm{st}}-Y, 0\right) \mathrm{d} t$

where stomatal flux $F_{\text {st }}$ (discussed below), and threshold, $Y$, are in nmole $\mathrm{O}_{3} \mathrm{~m}^{-2}$ (PLA) $\mathrm{s}^{-1}$ and POD itself has units mmole $\mathrm{O}_{3} \mathrm{~m}^{-2}$ (PLA) $\mathrm{s}^{-1}$. This integral is evaluated over time, from the start of the growing season (SGS), to the end (EGS). 
AOT40. - is the accumulated amount of ozone over the threshold value of $40 \mathrm{ppb}$, i.e.

$\mathrm{AOT} 40=\int \max \left(\mathrm{O}_{3}-40 \mathrm{ppb}, 0.0\right) \mathrm{d} t$

where the max function ensures that only ozone values exceeding $40 \mathrm{ppb}$ are included. The integral is taken over time, namely the relevant growing season for the vegetation concerned. The corresponding unit are ppb hours (abbreviated to $\mathrm{ppbh}$ ). The usage and definitions of AOT40 have changed over the years though, and also differ between UNECE and the EU. LRTAP (2009) give the latest definitions for UNECE work, and describes carefully how AOT40 values are best estimated for local conditions (using information on real growing seasons for example), and specific types of vegetation. Further, since $\mathrm{O}_{3}$ concentrations can have strong vertical gradients, it is important to specify the height of the $\mathrm{O}_{3}$ concentrations used. Although the EMEP model now generates a number of related outputs, the following definitions are usually most relevant:

AOT40 $f_{f}^{u c}$. - AOT40 calculated for forests using estimates of $\mathrm{O}_{3}$ at forest-top (uc: upper-canopy). This AOT40 is that defined for forests by LRTAP (2009), but using a default growing season of April-September.

$A O T 4 O_{c}^{u c}$. - AOT40 calculated for agricultural crops using estimates of $\mathrm{O}_{3}$ at the top of the crop. This AOT40 is close to that defined for agricultural crops by LRTAP (2009), but using a default growing season of May-July, and a default crop-height of $1 \mathrm{~m}$.

AOT $40_{f}^{G}, A O T 40_{c}^{G}$. - as above, but using the simple grid-average concentrations from the model's $3 \mathrm{~m}$ level.

The first two "canopy-top" definitions are in accordance with the recommendations of LRTAP (2009), and the two "grid" values are for comparison to AOT40 maps derived from observations.

In all cases only daylight hours are included, and for practical reasons we define daylight for the model outputs as the time when the solar zenith angle is equal to or less than $89^{\circ}$. (The proper UNECE definition uses clear-sky global radiation exceeding $50 \mathrm{~W} \mathrm{~m}^{-2}$ to define daylight). The EU definitions of AOT40 use day hours from 08:00-20:00.

For the development of the 1999 "Gothenburg" Protocol (http://www.unece.org/env/lrtap/), the metric used for assessing the risk to vegetation was AOT40. However, new critical levels based on $\mathrm{POD}_{Y}$ have now been agreed (Mills et al., $2011 \mathrm{~b}$, and references therein). For provision of data to support the use of these new approaches to IAM, a simplified approach to mapping ozone fluxes was defined by LRTAP (2009), in which one generic crop species was defined, and two generic forest species. The "IAM" species in Tables 3 and Table S16 correspond to these, although the phenology functions are somewhat simplified compared to the latest (2010) Mapping Manual update. In the model inputs, a tiny fraction of IAM_CR, IAM_DF and IAM_MF are added to each grid square where any vegetation is present, so we can calculate fluxes even in grids where the landuse data suggest no such species are present, providing a more comprehensive and easier to interpret spatial indication of risk.

This simplified approach for IAM was adopted because it was recognised that our knowledge of many critical inputs
Table 7. Ecosystems provided in deposition outputs, and associated EMEP landcover categories (see Table 3).

\begin{tabular}{ll}
\hline $\begin{array}{l}\text { Output ecosystem } \\
\text { label }\end{array}$ & $\begin{array}{l}\text { EMEP landcovers } \\
\left(\Lambda_{\mathrm{c}}\right)\end{array}$ \\
\hline Conif & $\mathrm{CF}, \mathrm{NF}$ \\
Decid & $\mathrm{DF}, \mathrm{BF}$ \\
Seminat & GR, SNL, MS \\
Crops & TC, RC, MC \\
\hline
\end{tabular}

(e.g. growing seasons and phenology, conductance parameters, elevation effects, soil water parameters, etc.) is too uncertain to allow accurate mapping of the real ozone flux to specific species. On the other hand the spatial distribution of fluxes is so different to that of AOT40 (Simpson et al., 2007a) that calculation of fluxes to a generic species was seen as an improvement upon the continued use of AOT40. It was also recognised that the IAM process (which balances health and vegetation impacts from many pollutants, against costs of emissions measures) could not take into account many different types of vegetation, and that only a few flux-maps could be included in the IAM optimisation work.

Although there are obvious similarities in the methods used to model upper-canopy stomatal fluxes $\left(F_{\mathrm{st}}\right)$ for the calculation of $\mathrm{POD}_{Y}$, and modelling of full-canopy fluxes for deposition purposes, these calculations have important differences. The $F_{\text {st }}$ values required for $\mathrm{POD}_{Y}$ represent maximum uptake to a small portion of the canopy, not net uptake to the whole canopy. These $F_{\text {st }}$ calculations are therefore performed as a parallel exercise to the deposition modelling, being performed from within the EMEP model's deposition routines, but having no feedback to the canopyscale deposition calculations required for the model's atmospheric chemistry calculations. The $f_{\text {light }}$ term (see Supplement, Sect. A6.2) is based upon $I_{\mathrm{PAR}}^{\mathrm{sun}}$, and soil-water limitations usually ignored (i.e. $f_{\mathrm{SW}}=1$ ). Further discussion of these type of calculations is given in Simpson et al. (2007a) and Tuovinen et al. (2009).

For these generic "IAM" species, the suffix gen can be

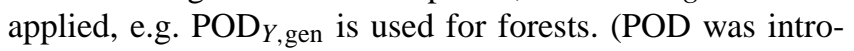
duced in 2009 as an easier and more descriptive term for the accumulated ozone flux than the former AFst term. The definitions of AFst and POD are identical however.)

\subsection{PM-water}

$\mathrm{PM}_{10}$ and $\mathrm{PM}_{2.5}$ mass determined with a gravimetric method is likely to include particle-bound water, which does not get completely removed (or condenses on the particles) under filters conditioning at temperature $20^{\circ} \mathrm{C}$ and relative humidity $50 \%$. To make comparison of calculated $\mathrm{PM}_{10}$ and $\mathrm{PM}_{2.5}$ concentrations with gravimetric measurements more consistent, the model accounts for particle water within the PM mass. The water content in $\mathrm{PM}_{2.5}$ and $\mathrm{PM}_{10}$ is calculated 
with the MARS equilibrium model (Binkowski and Shankar, 1995) for the conditions required for filters equilibration, i.e. temperature $20^{\circ} \mathrm{C}$ and relative humidity $50 \%$. As only fine SIA aerosols (i.e. $\mathrm{SO}_{4}^{2-}, \mathrm{NO}_{3}^{-}$and $\mathrm{NH}_{4}^{+}$) are included in the MARS model, the calculated water describes water in $\mathrm{PM}_{2.5}$. The calculated mass of water is added to both dry $\mathrm{PM}_{2.5}$ and $\mathrm{PM}_{10}$ masses when being compared with measured concentrations. Note that the components of sea salt aerosol is not included in the MARS model, leading to some underestimation of particle water.

The calculated aerosol water content depends on the mass of soluble PM fraction and on the type of salt mixture in particles. Accounting for particle water in calculated $\mathrm{PM}_{2.5}$ and $\mathrm{PM}_{10}$ has been shown to improve the general correspondence between model results and observations. However, there are caveats to the model esimates of particle-bound water as no proper verification of the calculated water content with measurements is presently available. Further details as well as results and initial evaluation of model calculation of particle water can be found in Tsyro (2005).

\section{Discussion and some future challenges}

As noted in the Introduction, the intention of this paper has been to document the EMEP MSC-W model version rv4, and for reasons of space this has not allowed much discussion of the background for model choices. One motivation for this focus on documentation is of course the importance of the EMEP model for European air pollution policy formulations. Another motivation is that the model is being widely used, applied in research projects and/or model intercomparison excercises, but so far only sparse and incomplete documentation has been available for the recent model versions.

Indeed, the model has taken part in a large number of inter-comparisons in recent years: Cuvelier et al. (2007); van Loon et al. (2007); Fiore et al. (2009); Huijnen et al. (2010); Jonson et al. (2010a); Colette et al. (2011, 2012); Langner et al. (2012), among others. In terms of performance, the EMEP model has ranked well in these studies, with consistently good performance for different pollutants (ozone, PM, etc.). In terms of complexity the EMEP model is fairly similar to other regional-scale European CTMs, such as MATCH (Robertson et al., 1999), CHIMERE (Bessagnet et al., 2004), or DEHM (Christensen, 1997; Frohn et al., 2001). All of these models have some flexibility with regard to chemical schemes, and have zooming-capabilities.

Given the complexity of any CTM, it is hard to limit a discussion of where the main limitations in a model are, and indeed it is difficult to know if the main source of uncertainty in models lies in their meteorological drivers, physical descriptions, chemical and/or aerosol schemes, or loss processes. The reliability of inputs such as emissions is a major cause of uncertainty. Here we address just a few areas where improvements are desired in the next few years, and where some work is ongoing. To limit the scope, we focus on particulate matter, which is probably the biggest challenge for both CTM models and policy development.

\section{(i) Aerosol size-distributions}

The standard EMEP model described here uses essentially two size-modes for particles, although our definitions of particle-size depend a little on the compound. This is a great simplification, which can be justified for current needs by the fact that the present version of model is mainly designed to calculate $\mathrm{PM}_{10}$ and $\mathrm{PM}_{2.5}$ mass closure (i.e. concentrations and chemical composition), which over the last decade has been the highest priority within the EMEP/LRTAP Convention framework. A pragmatic defence of this procedure is that in most comparisons with measurements (e.g. Fagerli and Aas, 2008; Simpson et al., 2006b, or EMEP status reports over many years) the EMEP model has been shown to perform quite well against measured PM mass. Problems are clearly apparent in some studies, for example in capturing hourly variations in $\mathrm{Nr}$ components measured in reactive nitrogen components close to agricultural areas (e.g. Aas et al., 2012), but it is unclear how far this problem can be related to size-distribution, and how much is due to other (so far unsolved) problems with model resolution or equilibrium dynamics (e.g. Aan de Brugh et al., 2012).

Still, the need for a more detailed description of the aerosol size-distribution is clearly apparent, on grounds of scientific realism (to capture the effects of for example in-cloud activation of particular size-fractions), an increasing need to link to climate issues (e.g. Liu et al., 2012), and also in terms of human health effects, where size distributions are also implicated. The challenge here is mainly to find an optimal balance between the number of bins/modes, in order to increase realism but preventing excessive $\mathrm{CPU}$-increases.

\section{(ii) Gas/aerosol equilibria (inorganic)}

As noted in Sect. 7.6, the MARS module we use for gas/aerosol partitioning of inorganic compounds into finemode aerosol cannot account for sea-salt and dust components, and we use a very simplified treatment of nitrate formation on coarse aerosol. In future we will likely replace MARS with a more comprehensive module (e.g. Fountoukis and Nenes, 2007), and likely use a kinetic (rather than equilibrium) approach for coarse nitrate formation, with explicit reactions of for example $\mathrm{HNO}_{3}$ with $\mathrm{NaCl}$ or dust. We have indeed been exploring such reactions, but this is ongoing work. Apart from the difficulty of predicting such components, there are also large gaps in our scientific understanding of nitrate composition - there are hardly any measurements of coarse-mode nitrate to compare against for example. 


\section{(iii) Organic aerosol}

For organic aerosol (OA), there are a large number of problems with all model formulations, something which inevitably follows from the complexity of OA itself, and our lack of understanding of the underlying science (e.g. Hallquist et al., 2009; $\mathrm{Ng}$ et al., 2010). Many of these issues (e.g. large uncertainties in emission inventories from both anthropogenic and biogenic sources, or in vapour pressure assumptions) have been discussed in relation to earlier EMEP modelling studies (Simpson et al., 2007b; Bergström et al., 2012), but here we briefly discuss an uncertainty arising from the use of the simplified 'NPAS' VBS scheme in the standard model. The NPAS scheme assumes that POA emissions can be treated as non-volatile, instead of treating them (and related emissions of SVOC and IVOC: semi- and intermediatevolatilty gases) as components of varying volatility (as in, e.g Robinson et al., 2007). In high-emission areas this NPAS scheme should lead to higher OA compared to a model that allows evaporation of some of the initially emitted POA. On the other hand, VBS schemes often postulate emissions of SVOC \& IVOC which are supposed to be unaccounted for in the official emission inventories (e.g. Shrivastava et al., 2008). This is likely more realistic, and provides a larger pool of VOC compounds from which partitioning to aerosol can occur, but it is also a large source of uncertainty.

There are two main reasons why we choose to use nonvolatile POA emissions in the "standard" EMEP model code (that used for policy-associated runs): (1) The volatility distribution of POA and associated SVOC and IVOC compounds is poorly known; the amount of SVOC + IVOC emissions is probably substantial, but so far we have only a very limited number of (American) studies with which to estimate this contribution (e.g. Shrivastava et al., 2008); (2) official European emission inventories used for policy modelling consist of PM compounds which are assumed to be inert, as well as VOC emissions. No consideration of volatility is made in either the PM or VOC inventories. For policy modelling it is necessary to keep these POA and VOC emission totals the same as in the official emission inventories.

In order to assess the sensitivity of the model to this assumption, we have used the schemes presented by Bergström et al. 2012 to compare model versions with and without this inert POA assumption. The results, illustrated in Supplement Fig. S2, show that total yearly average OA concentrations (in $\mathrm{PM}_{2.5}$ ) over most of the European land-area are 10-20\% lower when we use inert POA emissions (NPAS scheme) than if we use volatility-based emissions and aging of the emitted semi- and intermediate volatility OC emissions - an effect of the extra SVOC+IVOC assumed in the PAA VBS scheme which generates more OA because of aging processes. For some high-emission areas the inert assumption leads to much higher yearly average OA than the volatility based approach. The biggest effects are found over Paris, where we obtain more than $40 \%$ higher fine OA with the inert POA model.

The volatility question is thus important, but one of many uncertainties with regard to OA modelling. There is clearly an urgent need for new measurement and inventory data on emissions and volatility distributions in Europe though, if we are to take account of these properly in future research or policy-related modelling.

\section{(iv) Dispersion/resolution issues}

The final major challenge we will mention is that of model resolution, especially in the vertical. The EMEP model currently has a lowest layer of about $90 \mathrm{~m}$ deep, so generates concentration data which is appropriate for about $45 \mathrm{~m}$. This is clearly a simplification, especially in wintertime for those pollutants that have major ground-level sources. Woodburning emissions are a clear example of this, and their importance for wintertime OA concentrations has been stressed in many studies (see Simpson et al., 2007b; Bergström et al., 2012, and references cited therein), but there is no easy solution. Simply reducing the thickness of the lowest model layer is also unrealistic, since this quickly leads to an imbalance in the horizontal and vertical scales. It is not realistic for example to disperse the emissions from a point source through $50 \mathrm{~km} \times 50 \mathrm{~km}$ in the horizontal, but only $10 \mathrm{~m}$ in the vertical.

Another major problem for this situation is that modelling of the stable boundary layers found in wintertime is notoriously difficult, and there is generally very little data with which to evaluate the vertical dispersion estimated by models. Work is also ongoing to find the best compromise in terms of grid resolution and model physics.

\section{Conclusions}

The Meteorological Synthesizing Centre - West (MSC-W) of EMEP has been performing model calculations in support of UNECE for more than 30 years. The EMEP MSC-W chemical transport model is still one of the key models used in policy support in Europe. It is central to UN-ECE work, with a mandate to provide scientific support to the development of air pollution reduction Protocols, and is the sole provider of source-receptor matrices to the IIASA GAINS model (which is central to EU policy work), and is used in many EU projects alongside other chemical transport models.

The MSC-W models have been increasing in complexity and capabilities over this time-period, and today the MSC-W model is used to simulate photo-oxidants and both inorganic and organic aerosols, on scales ranging from national studies at ca. $5 \mathrm{~km}$ resolution to global scale.

The last full documentation of the EMEP MSC-W model is almost ten years old (Simpson et al., 2003a), referring 
to version rv1.7 (or EMEP-03 for simplicity). The model has changed in numerous ways (both large and small) since this document was written. These changes include revised methods for calculating mixing heights and eddy diffusion coefficients (for stable and neutral conditions), new temporal variation factors (based upon degree-days) for the SNAP2 (mainly residential combustion) emission category, and changed summer/winter ratios for the SNAP-1 (power station) category, a complete revision of the spatial mapping for BVOC emissions (plus an update of the emission factors), addition of soil NO procedures for both global modelling and finer-scale European modelling, addition of seasalt, dust, forest-fires and secondary organic aerosols (SOA) to the standard model. The model has become very flexible, and can now be run with several meteorological drivers, and has the ability to run in nested mode (allowing zooming). A chemical pre-processor has allowed a number of other chemical schemes to be implemented, ranging in complexity from less than a hundred to more than a thousand reactions (the CRI v2 scheme). For sulphur and nitrogen compounds the dry-deposition equations have changed substantially since EMEP-03 (e.g. for the non-stomatal conductance, treatment of humidity, snow, etc.). The aerosol dry deposition scheme is completely new. The MARS equilibrium solver has replaced the earlier EQSAM code, and water associated with PM is now calculated with the same MARS model as used for gas/aerosol partitioning calculations.

Smaller changes include revisions in the equations concerning the stomatal deposition pathway, and in parameter values for land-cover characteristics, the vertical distribution of emissions, collection efficiencies of fine particles, and the VOC speciation. New sources of aircraft emissions and shipping emissions are being used.

In this paper, we have documented the current state of the model, version rv4. The model is continually evolving, but we hope that the rv4 model version provides a good base against which future model changes can be compared. The model code itself is available at www.emep.int, along with the datasets required to run for a full year over Europe.

\section{Supplementary material related to this article is available online at: http://www.atmos-chem-phys.net/12/ 7825/2012/acp-12-7825-2012-supplement.pdf.}

Acknowledgements. This work was supported by EMEP under UNECE. Important updates to the EMEP model were made as part of the EU 6th Framwork programmes EUCAARI (Contract No. 34684) and Nitro-Europe (FP6-2004-No017841-2.). The work of RB was supported by the Swedish Research Programme for Clean Air (SCARP), LDE by DEFRA (UK Dept. of Environ., Food and Rural Affairs, contract AQ0601), and CR (who was then at Forschungszentrum Jülich $\mathrm{GmbH}$, Institut für Energie- und Klimaforschung - Troposphäre) was suppored by the a grant from the Swedish Tellus project (Centre of Earth Systems Science at the University of Gothenburg). Thanks are also due to Willem Asman, Bertrand Bessagnet, Eiko Nemitz, Ron Smith, Mark Sutton, Massimo Vieno, Stefan Unger, Guus Velders, and a large number of colleagues who have offered helpful advice, corrections to documentation, testing of the code, and ideas over the years.

Edited by: H. C. Hansson

\section{References}

Aan de Brugh, J. M. J., Henzing, J. S., Schaap, M., Morgan, W. T., van Heerwaarden, C. C., Weijers, E. P., Coe, H., and Krol, M. C.: Modelling the partitioning of ammonium nitrate in the convective boundary layer, Atmos. Chem. Phys., 12, 3005-3023, doi:10.5194/acp-12-3005-2012, 2012.

Aas, W., Tsyro, S., Bieber, E., Bergström, R., Ceburnis, D., Ellermann, T., Fagerli, H., Frölich, M., Gehrig, R., Makkonen, U., Nemitz, E., Otjes, R., Perez, N., Perrino, C., Prévôt, A. S. H., Putaud, J.-P., Simpson, D., Spindler, G., Vana, M., and Yttri, K. E.: Lessons learnt from the first EMEP intensive measurement periods, Atmos. Chem. Phys. Discuss., 12, 3731-3780, doi:10.5194/acpd-12-3731-2012, 2012.

Aiken, A. C., Decarlo, P. F., Kroll, J. H., Worsnop, D. R., Huffman, J. A., Docherty, K. S., Ulbrich, I. M., Mohr, C., Kimmel, J. R., Sueper, D., Sun, Y., Zhang, Q., Trimborn, A., Northway, M., Ziemann, P. J., Canagaratna, M. R., Onasch, T. B., Alfarra, M. R., Prevot, A. S. H., Dommen, J., Duplissy, J., Metzger, A., Baltensperger, U., and Jimenez, J. L.: O/C and OM/OC ratios of primary, secondary, and ambient organic aerosols with highresolution time-of-flight aerosol mass spectrometry, Environ. Sci. Technol., 42, 4478-4485, doi:10.1021/es703009q, 2008.

Alfaro, S. D. and Gomes, L.: Modeling mineral aerosol production by wind erosion: Emission intensities and aerosol size distributions in source areas., J. Geophys. Res., 106, 18075-18084, doi:10.1029/2000jd900339, 2001.

Alonso, R., Elvira, S., Sanz, M. J., Gerosa, G., Emberson, L. D., Bermejo, V., and Gimeno, B. S.: Sensitivity analysis of a parameterization of the stomatal component of the DO3SE model for Quercus ilex to estimate ozone fluxes, Environ. Poll., 155, 473480, doi:10.1016/j.envpol.2008.01.032, 2008.

Aleksic, N., Roy, K., Sistla, G., Dukett, J., Houck, N., and Casson, P.: Analysis of cloud and precipitation chemistry at Whiteface Mountain, NY, Atmos. Environ., 43, 2709-2716, doi:10.1016/j.atmosenv.2009.02.053, 2009.

Andersson-Sköld, Y. and Simpson, D.: Comparison of the chemical schemes of the EMEP MSC-W and the IVL photochemical trajectory models, EMEP MSC-W Note 1/97, The Norwegian Meteorological Institute, Oslo, Norway, 1997.

Andersson-Sköld, Y. and Simpson, D.: Comparison of the chemical schemes of the EMEP MSC-W and the IVL photochemical trajectory models, Atmos. Environ., 33, 1111-1129, 1999.

Andersson-Sköld, Y. and Simpson, D.: Secondary organic aerosol formation in Northern Europe: a model study, J. Geophys. Res., 106, 7357-7374, 2001.

Aneja, V. and Kim, D.: Chemical-dynamics of clouds at Mt Mitchell, North-Carolina, J. Air Waste Manage. Assoc., 43, 
1074-1083, 1993.

Angelbratt, J., Mellqvist, J., Simpson, D., Jonson, J. E., Blumenstock, T., Borsdorff, T., Duchatelet, P., Forster, F., Hase, F., Mahieu, E., De Mazière, M., Notholt, J., Petersen, A. K., Raffalski, U., Servais, C., Sussmann, R., Warneke, T., and Vigouroux, C.: Carbon monoxide $(\mathrm{CO})$ and ethane $\left(\mathrm{C}_{2} \mathrm{H}_{6}\right)$ trends from ground-based solar FTIR measurements at six European stations, comparison and sensitivity analysis with the EMEP model, Atmos. Chem. Phys., 11, 9253-9269, doi:10.5194/acp-11-92532011, 2011.

Arakawa, A. and Lamb, V.: Computational design of the basic dynamical processes of the UCLA general circulation model, Meth. Comput. Phys., 17, 173-265, 1977.

Atkinson, R., Baulch, D. L., Cox, R. A., Crowley, J. N., Hampson, R. F., Hynes, R. G., Jenkin, M. E., Rossi, M. J., and Troe, J.: Evaluated kinetic and photochemical data for atmospheric chemistry: Volume $\mathrm{I}$ - gas phase reactions of $\mathrm{O}_{\mathrm{x}}, \mathrm{HO}_{\mathrm{x}}, \mathrm{NO}_{\mathrm{x}}$ and $\mathrm{SO}_{\mathrm{x}}$ species, Atmos. Chem. Phys., 4, 1461-1738, doi:10.5194/acp-41461-2004, 2004.

Atkinson, R., Baulch, D. L., Cox, R. A., Crowley, J. N., Hampson, R. F., Hynes, R. G., Jenkin, M. E., Rossi, M. J., Troe, J., and IUPAC Subcommittee: Evaluated kinetic and photochemical data for atmospheric chemistry: Volume II - gas phase reactions of organic species, Atmos. Chem. Phys., 6, 3625-4055, doi:10.5194/acp-6-3625-2006, 2006.

Baker, J.: Recalcitrant problems in environmental instrumentation, Agronomy Journal, 95, 1404-1407, Symposium on the Soil Plant Atmosphere Continuum, Charlotte, North Carolina, 2001, 2003.

Beljaars, A. C. M.: The parameterisation of surface fluxes in largescale models under free convection., Q. J. Roy. Meteorol. Soc., 121, 255-270, 1994.

Benedictow, A.: Documentation and verification of the 1999 PARLAM-PS meteorological fields used as input for Eulerian EMEP model, Tech. rep., The Norwegian Meteorological Institute, Oslo, Norway, research Note no. 111, (Reports also available for 1980, 1985, 1995, 1999, 2000 and 2001, see www.emep. int), 2003.

Berge, E.: A regional numerical sulfur dispersion model using a meteorological model with explicit treatment of clouds, Tellus B, 42, 389-407, doi:10.1034/j.1600-0889.1990.t01-3-00001.x, 1990.

Berge, E. and Jakobsen, H. A.: A regional scale multi-layer model for the calculation of long-term transport and deposition of air pollution in Europe, Tellus, 50, 205-223, 1998.

Berglen, T., Berntsen, T., Isaksen, I., and Sundet, J.: A global model of the coupled sulfur/oxidant chemistry in the troposphere: The sulfur cycle, J. Geophys. Res., 109, D19310, doi:10.1016/j.atmosenv.2004.02.034, 2004.

Bergström, R., Denier van der Gon, H., Prevot, A., Yttri, K., and Simpson, D.: Modelling of organic aerosols over Europe (20022007) using a volatility basis set (VBS) framework with application of different assumptions regarding the formation of secondary organic aerosol, Atmos. Chem. Phys., in review, 2012.

Bertram, T. H. and Thornton, J. A.: Toward a general parameterization of $\mathrm{N}_{2} \mathrm{O}_{5}$ reactivity on aqueous particles: the competing effects of particle liquid water, nitrate and chloride, Atmos. Chem. Phys., 9, 8351-8363, doi:10.5194/acp-9-8351-2009, 2009.

Bertram, T. H., Thornton, J. A., Riedel, T. P., Middlebrook, A. M., Bahreini, R., Bates, T. S., Quinn, P. K., and Coffman, D. J.: Direct observations of $\mathrm{N}_{2} \mathrm{O}_{5}$ reactivity on ambient aerosol particles, Geophys. Res. Lett., 36, L19803, doi: 10.1029/2009GL040248, 2009.

Bessagnet, B., Hodzic, A., Vautard, R., Beekmann, M., Cheinet, S., Honore, C., Liousse, C., and Rouil, L.: Aerosol modeling with CHIMERE - preliminary evaluation at the continental scale, Atmos. Environ., 38, 2803-2817, doi:10.1016/j.atmosenv.2004.02.034, 2004.

Bieser, J., Aulinger, A., Matthias, V., Quante, M., and van der Gon, H. D.: Vertical emission profiles for Europe based on plume rise calculations, Environmental Pollution, 159, 29352946, doi:10.1016/j.envpol.2011.04.030, 2011.

Binkowski, F. and Shankar, U.: The Regional Particulate Matter Model .1. Model description and preliminary results, J. Geophys. Res., 100, 26191-26209, 1995.

Bjørge, D. and Skålin, R.: PARLAM - the parallel HIRLAM version at DNMI, Research Report 27, The Norwegian Meteorological Institute, Oslo, Norway, 1995.

Blackadar, A. K.: High resolution models of the planetary boundary layer. Advances in environment and scientific engineering, London: Gordon and Breach, 1979.

Bojkov, R.: Surface ozone concentrations during the second half of the nineteenth century, J. Clim. Appl. Met., 25, 343-352, 1986.

Bott, A.: A positive definite advection scheme obtained by nonlinear re-normalization of the advection fluxes, Mon. Weather Rev., 117, 1006-1015, 1989a.

Bott, A.: Reply, Mon. Weather Rev., 117, 2633-2636, 1989 b.

Brown, S., Ryerson, T., Wollny, A., Brock, C., Peltier, R., Sullivan, A., Weber, R., Dube, W., Trainer, M., Meagher, J., Fehsenfeld, F., and Ravishankara, A.: Variability in nocturnal nitrogen oxide processing and its role in regional air quality, Science, 311, 6770, doi:10.1126/science.1120120, 2006.

Brown, S. S., Dube, W. P., Fuchs, H., Ryerson, T. B., Wollny, A. G., Brock, C. A., Bahreini, R., Middlebrook, A. M., Neuman, J. A., Atlas, E., Roberts, J. M., Osthoff, H. D., Trainer, M., Fehsenfeld, F. C., and Ravishankara, A. R.: Reactive uptake coefficients for $\mathrm{N}_{2} \mathrm{O}_{5}$ determined from aircraft measurements during the Second Texas Air Quality Study: Comparison to current model parameterizations, J. Geophys. Res., 114, D00F10, doi:10.1029/2008JD011679, 2009.

Büker, P., Morrissey, T., Briolat, A., Falk, R., Simpson, D., Tuovinen, J.-P., Alonso, R., Barth, S., Baumgarten, M., Grulke, N., Karlsson, P. E., King, J., Lagergren, F., Matyssek, R., Nunn, A., Ogaya, R., Peñuelas, J., Rhea, L., Schaub, M., Uddling, J., Werner, W., and Emberson, L. D.: DO3SE modelling of soil moisture to determine ozone flux to forest trees, Atmos. Chem. Phys., 12, 5537-5562, doi:10.5194/acp-12-5537-2012, 2012.

Burkhardt, J., Flechard, C. R., Gresens, F., Mattsson, M., Jongejan, P. A. C., Erisman, J. W., Weidinger, T., Meszaros, R., Nemitz, E., and Sutton, M. A.: Modelling the dynamic chemical interactions of atmospheric ammonia with leaf surface wetness in a managed grassland canopy, Biogeosciences, 6, 67-84, doi:10.5194/bg-667-2009, 2009.

Butterbach-Bahl, K., Kahl, M., Mykhayliv, L., Werner, C., Kiese, R., and Li, C.: A European-wide inventory of soil NO emissions using the biogeochemical models DNDC/Forest-DNDC, Atmos. Environ., 43, 1392-1402, doi:10.1016/j.atmosenv.2008.02.008, 2009. 
Chang, W. L., Bhave, P. V., Brown, S. S., Riemer, N., Stutz, J., and Dabdub, D.: Heterogeneous Atmospheric Chemistry, Ambient Measurements, and Model Calculations of $\mathrm{N}_{2} \mathrm{O}_{5}$ : A Review, Aerosol Sci. Technol., 45, 665-695, doi:10.1080/02786826.2010.551672, 2011.

Christensen, J. H.: The Danish Eulerian Hemispheric Model - a Three-Dimensional Air Pollution Model Used for the Arctic, Atmos. Environ., 31, 4169-4191, 1997.

Claussen, M.: Flux aggregation at large scales - on the limits of validity of the concept of blending height, J. Hydrology, 166, 371-382, 1995.

Cofala, J., Amann, M., Z., Kupiainen, K., and Hoglund-Isaksson, L.: Scenarios of global anthropogenic emissions of air pollutants and methane until 2030, Atmos. Environ., 41, 8486-8499, 2007.

Colette, A., Granier, C., Hodnebrog, Ø., Jakobs, H., Maurizi, A., Nyiri, A., Bessagnet, B., D’Angiola, A., D’Isidoro, M., Gauss, M., Meleux, F., Memmesheimer, M., Mieville, A., Rouil, L., Russo, F., Solberg, S., Stordal, F., and Tampieri, F.: Air quality trends in Europe over the past decade: a first multi-model assessment, Atmos. Chem. Phys., 11, 11657-11678, doi:10.5194/acp11-11657-2011, 2011.

Colette, A., Granier, C., Hodnebrog, Ø., Jakobs, H., Maurizi, A., Nyiri, A., Rao, S., Amann, M., Bessagnet, B., D’Angiola, A., Gauss, M., Heyes, C., Klimont, Z., Meleux, F., Memmesheimer, M., Mieville, A., Rouill, L., Russo, F., Schucht, S., Simpson, D., Stordal, F., Tampieri, F., and Vrac, M.: Future air quality in Europe: a multi-model assessment of projected exposure to ozone, Atmos. Chem. Phys. Discuss., 12, 14771-14812, doi:10.5194/acpd-12-14771-2012, 2012.

Cuvelier, C., Thunis, P., Vautard, R., Amann, M., Bessagnet, B., Bedogni, M., Berkowicz, R., Brandt, J., Brocheton, F., Builtjes, P., Carnavale, C., Coppalle, A., Denby, B., Douros, J., Graf, A., Hellmuth, O., Hodzic, A., Honore, C., Jonson, J., Kerschbaumer, A., de Leeuw, F., Minguzzi, E., Moussiopoulos, N., Pertot, C., Peuch, V., Pirovano, G., Rouil, L., Sauter, F., Schaap, M., Stern, R., Tarrason, L., Vignati, E., Volta, M., White, L., Wind, P., and Zuber, A.: CityDelta: A model intercomparison study to explore the impact of emission reductions in European cities in 2010, Atmos. Environ., 41, 189-207, 2007.

de Smet, P. and Hettelingh, J.-P.: Intercomparison of Current Landuse/Land Cover Databases, in: Modelling and Mapping of Critical Thresholds in Europe. Status report 2001, edited by: Posch, M., de Smet, P., Hettelingh, J.-P., and Downing, R., Coordination Centre for Effects, RIVM, Bilthoven, The Netherlands, 2001.

DeMore, W., Sander, S., Golden, D., Hampson, R., Kurylo, M., Howard, C., Ravishankara, A., Kolb, C., and Molina, M.: Chemical kinetics and photochemical data for use in stratospheric modelling, JPL Publication, 97-4, 1997.

Denier van der Gon, H., Jozwicka, M., Hendriks, E., Gondwe, M., and Schaap, M.: Mineral dust as a component of particulate matter, Tno, bop - wp2 - report, report 500099003, TNO Delft, The Netherlands, www.pbl.nl, iSSN:1875-2322 (print) ISSN: 18752314 (on line), 2010.

Derwent, R., Simmonds, P., Seuring, S., and Dimmer, C.: Observations and interpretation of the seasonal cycles in the surface concentrations of ozone and carbon monoxide at Mace Head, Ireland from 1990 to 1994, Atmos. Environ., 32, 145-157, 1998.

Donahue, N. M., Robinson, A. L., and Pandis, S. N.: Atmospheric organic particulate matter: From smoke to secondary organic aerosol, Atmos. Environ., 43, 94-106, doi:10.1016/j.atmosenv.2008.09.055, 2009.

Dutsch, M. U.: The ozone distribution in the atmosphere, Can. J. Chem., 52, 1491-1504, 1974.

Ehhalt, D. H., Schmidt, U., Zander, R., Demoulin, P., and Rinsland, C.: Seasonal cycle and secular trend of the total and tropospheric column abundance of ethane above the Jungfraujoch, J. Geophys. Res., 96, 4985-4994, 1991.

Eliassen, A. and Saltbones, J.: Modelling of long-range transport of sulphur over Europe: a two year model run and some experiments, Atmos. Environ., 17, 1457-1473, 1983.

Eliassen, A., Hov, Ø., Isaksen, I., Saltbones, J., and Stordal, F.: A Lagrangian long-range transport model with atmospheric boundary layer chemistry, J. Appl. Meteorol., 21, 1645-1661, 1982.

Emberson, L., Simpson, D., Tuovinen, J.-P., Ashmore, M., and Cambridge, H.: Towards a model of ozone deposition and stomatal uptake over Europe, EMEP MSC-W Note 6/2000, The Norwegian Meteorological Institute, Oslo, Norway, 2000a.

Emberson, L., Wieser, G., and Ashmore, M.: Modelling of stomatal conductance and ozone flux of Norway spruce: comparison with field data, Environ. Poll., 109, 393-402, 2000b.

Emberson, L., Ashmore, M., Simpson, D., Tuovinen, J.-P., and Cambridge, H.: Modelling and mapping ozone deposition in Europe, Water Air Soil Pollut., 130, 577-582, 2001.

Emberson, L. D., Büker, P., and Ashmore, M. R.: Assessing the risk caused by ground level ozone to European forest trees: A case study in pine, beech and oak across different climate regions, Environ. Poll., 147, 454-466, doi:10.1016/j.envpol.2006.10.026, 2007.

Emmons, L. K., Hauglustaine, D. A., Müller, J.-F., Carroll, M. A., Brasseur, G. P., Brunner, D., Staehelin, J., Thouret, V., and Marenco, A.: Data composites of airborne observations of tropospheric ozone and its precursors, J. Geophys. Res., 105, $20497-$ 20538, doi:10.1029/2000JD900232, 2000.

Erisman, J. W., Van Pul, A., and Wyers, P.: Parametrization of surface resistance for the quantification of atmospheric deposition of acidifying pollutants and ozone, Atmos. Environ., 28, 25952607, 1994.

Erisman, J. W., Hensen, A., Fowler, D., Flechard, C. R., Grüner, A., Spindler, G., Duyzer, J. H., Weststrate, H., Römer, F., Vonk, A. W., and Jaarsveld, H. V.: Dry Deposition Monitoring in Europe, Water Air Soil Pollut.: Focus, 1, 17-27, 2001.

Fagerli, H. and Aas, W.: Trends of nitrogen in air and precipitation: Model results and observations at EMEP sites in Europe, 19802003, Environ. Poll., 154, 448-461, 2008.

Fagerli, H., Legrand, M., Preunkert, S., Vestreng, V., Simpson, D., and Cerquira, M.: Modeling historical long-term trends of sulfate, ammonium and elemental carbon over Europe: A comparison with ice core records in the Alps, J. Geophys. Res., 112, D23S13, doi:10.1029/2006JD008044, 2007.

Fagerli, H., Nemitz, E., Simpson, D., Smith, R., Coyle, M., Erisman, J.-W., and Sutton, M.: A first approach to model the codeposition of $\mathrm{NH}_{3}$ and $\mathrm{SO}_{2}$ in a regional scale model: Derivation of an operational parametrisation and the effect on modelled European trends of sulphur dioxide, in preparation, 2012.

Fécan, F., Marticorena, B., and Bergametti, G.: Parametrization of the increase of the aeolian erosion threshold wind friction velocity due to soil moisture for arid and semi-arid areas, Ann. Geophys., 17, 149-157, doi:10.1007/s00585-999-0149-7, 1999. 
Fiore, A., Dentener, F., Wild, O., Cuvelier, C., Schultz, M., Textor, C., Schulz, M., Atherton, C., Bergmann, D., Bey, I., Carmichael, G., Doherty, R., Duncan, B., Faluvegi, G., Folberth, G., Garcia Vivanco, M., Gauss, M., Gong, S., Hauglustaine, D., Hess, P., Holloway, T., Horowitz, L., Isaksen, I., Jacob, D., Jonson, J., Kaminski, J., keating, T., Lupu, A., MacKenzie, I., Marmer, E., Montanaro, V., Park, R., Pringle, K., Pyle, J., Sanderson, M., Schroeder, S., Shindell, D., Stevenson, D., Szopa, S., Van Dingenen, R., Wind, P., Wojcik, G., Wu, S., Zeng, G., and Zuber, A.: Multi-model estimates of intercontinental sourcereceptor relationships for ozone pollution, J. Geophys. Res., 114, doi:10.1029/2008JD010816, doi:10.1029/2008JD010816, 2009.

Flechard, C. R., Fowler, D., Sutton, M. A., and Cape, J. N.: A dynamic chemical model of bi-directional ammonia exchange between semi-natural vegetation and the atmosphere, Q. J. Roy. Meteorol. Soc., 125, 2611-2641, 1999.

Flechard, C. R., Nemitz, E., Smith, R. I., Fowler, D., Vermeulen, A. T., Bleeker, A., Erisman, J. W., Simpson, D., Zhang, L., Tang, Y. S., and Sutton, M. A.: Dry deposition of reactive nitrogen to European ecosystems: a comparison of inferential models across the NitroEurope network, Atmos. Chem. Phys., 11, 2703-2728, doi:10.5194/acp-11-2703-2011, 2011.

Fowler, D. and Erisman, J.: Biosphere/Atmosphere Exchange of Pollutants. Overview of subproject BIATEX-2, in: Towards Cleaner Air for Europe - Science, Tools and Applications, Part 2. Overviews from the Final Reports of the EUROTRAC-2 Subprojects, edited by: Midgley, P. and Reuther, M., Margraf Verlag, Weikersheim, also available at: http://www.gsf.de/eurotrac/ publications/, 2003.

Fowler, D., Coyle, M., Flechard, C., Hargreaves, K., Nemitz, E., Storeton-West, R., Sutton, M., and Erisman, J.-W.: Advances in micrometeorological methods for the measurement and interpretation of gas and particle nitrogen fluxes, Plant and Soil, 228, 117-129, 2001.

Fountoukis, C. and Nenes, A.: ISORROPIA II: a computationally efficient thermodynamic equilibrium model for $\mathrm{K}^{+}$ $\mathrm{Ca}^{2+}-\mathrm{Mg}^{2+}-\mathrm{NH}_{4}^{+}-\mathrm{Na}^{+}-\mathrm{SO}_{4}^{2-}-\mathrm{NO}_{3}^{-}-\mathrm{Cl}^{-}-\mathrm{H}_{2} \mathrm{O}$ aerosols, Atmos. Chem. Physics, 7, 4639-4659, doi:10.5194/acp-7-46392007, http://www.atmos-chem-phys.net/7/4639/2007/, 2007.

Fowler, D., Pilegaard, K., Sutton, M., Ambus, P., Raivonen, M., Duyzer, J., Simpson, D., Fagerli, H., Fuzzi, S., Schjoerring, J., Granier, C., Neftel, A., Isaksen, I., Laj, P., Maione, M., Monks, P., Burkhardt, J., Daemmgen, U., Neirynck, J., Personne, E., Wichink-Kruit, R., Butterbach-Bahl, K., Flechard, C., Tuovinen, J., Coyle, M., Gerosa, G., Loubet, B., Altimir, N., Gruenhage, L., Ammann, C., Cieslik, S., Paoletti, E., Mikkelsen, T., Ro-Poulsen, H., Cellier, P., Cape, J., Horváth, L., Loreto, F., Niinemets, Ü., Palmer, P., Rinne, J., Misztal, P., Nemitz, E., Nilsson, D., Pryor, S., Gallagher, M., Vesala, T., Skiba, U., Brüeggemann, N., Zechmeister-Boltenstern, S., Williams, J., O’Dowd, C., Facchini, M., de Leeuw, G., Flossman, A., Chaumerliac, N., and Erisman, J.: Atmospheric composition change: Ecosystems-Atmosphere interactions, Atmos. Environ., 43, 5193-5267, doi:10.1016/j.atmosenv.2009.07.068, 2009.

Friedrich, R. and Reis, S. (Eds.): Emissions of Air Pollutants - Measurements, Calculation, Uncertainties - Results from the EUROTRAC-2 Subproject GENEMIS, Springer Publishers, Berlin, Heidelberg, Germany, 2004.
Frohn, L. M., Christensen, J. H., Brandt, J., and Hertel, O.: Development of a high resolution integrated nested model for studying air pollution in Denmark, Phys. Chem. Earth Pt. B, 26, 769-774, 2001.

Gallagher, M. W., Beswick, K. M., Duyzer, J., Westrate, H., Choularton, T. W., and Hummelshoj, P.: Measurements of aerosol fluxes to Speulder forest using a micrometeorological technique, Atmos. Environ., 31, 359-373, 1997.

Garratt, J.: The atmospheric boundary layer, Cambridge University Press, Cambridge, England, UK, 1992.

Gauss, M., Benedictow, A., and Hjellbrekke, A.-G.: Photo-oxidants: validation and combined maps, Supplementary material to emep status report 1/2011, available online at www.emep.int, The Norwegian Meteorological Institute, Oslo, Norway, 2011.

Gery, M., Whitten, G., Killus, J., and Dodge, M.: A photochemical kinetics mechanism for urban and regional scale computer modelling, J. Geophys. Res., 94, 12925-12956, 1989.

Gomes, L., Rajot, J. L., Alfaro, S. C., and Gaudichet, A.: Validation of a dust production model from measurements performed in semi-arid agricultural areas of Spain and Niger, Catena, 52, 257-271, 2003.

Gong, S., Barrie, L., and Blanchet, J.: Modeling sea-salt aerosols in the atmosphere .1. Model development, J. Geophys. Res., 102, 3805-3818, doi:10.1029/96JD02953, 1997.

Granat, L. and Johansson, C.: Dry Deposition of $\mathrm{SO}_{2}$ and $\mathrm{NO}_{\mathrm{x}}$ in Winter, Atmos. Environ., 17, 191-192, 1983.

Grennfelt, P. and Hov, O.: Regional air pollution at a turning point, Ambio, 34, 2-10, 2005.

Grini, A., Myhre, G., Zender, C. S., and Isaksen, I. S. A.: Model simulation of dust sources and transport in the global atmosphere: Effect of soil erodibility and wind speed variability, J. Geophys. Res., 110, D02205, doi:10.1029/2004JD005037, 2005.

Guenther, A., Zimmerman, P., Harley, P., Monson, R., and Fall, R.: Isoprene and monoterpene rate variability: model evaluations and sensitivity analyses, J. Geophys. Res., 98, 12609-12617, 1993.

Guenther, A., Zimmerman, P., and Wildermuth, M.: Natural volatile organic compound emission rate estimates for U.S. woodland landscapes, Atmos. Environ., 28, 1197-1210, 1994.

Guenther, A., Hewitt, C., Erickson, D., Fall, R., Geron, C., Graedel, T., Harley, P., Klinger, L., Lerdau, M., McKay, W., Pierce, T., Scholes, R., Steinbrecher, R., Tallamraju, R., Taylor, J., and Zimmerman, P.: A global model of natural volatile organic compound emissions, J. Geophys. Res., 100, 8873-8892, 1995.

Hallquist, M., Wenger, J. C., Baltensperger, U., Rudich, Y., Simpson, D., Claeys, M., Dommen, J., Donahue, N. M., George, C., Goldstein, A. H., Hamilton, J. F., Herrmann, H., Hoffmann, T., Iinuma, Y., Jang, M., Jenkin, M. E., Jimenez, J. L., Kiendler-Scharr, A., Maenhaut, W., McFiggans, G., Mentel, Th. F., Monod, A., Prévôt, A. S. H., Seinfeld, J. H., Surratt, J. D., Szmigielski, R., and Wildt, J.: The formation, properties and impact of secondary organic aerosol: current and emerging issues, Atmos. Chem. Phys., 9, 5155-5236, doi:10.5194/acp-9-51552009, 2009.

Hayman, G., Abbott, J., Davies, T., Thomson, C., Jenkin, M., Thetford, R., and Fitzgerald, P.: The Ozone Source-Receptor Model - a Tool for UK Ozone Policy, Atmos. Environ., 44, 4283-4297, doi:10.1016/j.atmosenv.2010.06.013, 2010.

Hayman, G., Bergström, R., Jenkin, M., and Simpson, D.: Modelling Photochemical Oxidants in Europe: benchmarking seven 
chemical mechanisms, in preparation, 2012.

Henzing, J. S., Olivié, D. J. L., and van Velthoven, P. F. J.: A parameterization of size resolved below cloud scavenging of aerosols by rain, Atmos. Chem. Phys., 6, 3363-3375, doi:10.5194/acp-63363-2006, 2006.

Hicks, B. and Liss, P.: Transfer of $\mathrm{SO}_{2}$ and other reactive gases across air-sea interface, Tellus, 28, 348-354, 1976.

Hodnebrog, Ø., Solberg, S., Stordal, F., Svendby, T., Simpson, D., Gauss, M., Hilboll, A., Pfister, G., Turquety, S., Richter, A., Burrows, J. P., and Denier van der Gon, H.A.C.: A model study of the Eastern Mediterranean ozone levels during the hot summer of 2007, Atmos. Chem. Phys. Discuss., in review, 2012.

Hov, Ø., Eliassen, A., and Simpson, D.: Calculation of the distribution of $\mathrm{NO}_{\mathrm{x}}$ compounds in Europe, in: Troposheric ozone. Regional and global scale interactions, edited by: Isaksen, I., 239262, D. Reidel, Dordrecht, The Netherlands, 1988.

Huijnen, V., Eskes, H. J., Poupkou, A., Elbern, H., Boersma, K. F., Foret, G., Sofiev, M., Valdebenito, A., Flemming, J., Stein, O., Gross, A., Robertson, L., D'Isidoro, M., Kioutsioukis, I., Friese, E., Amstrup, B., Bergstrom, R., Strunk, A., Vira, J., Zyryanov, D., Maurizi, A., Melas, D., Peuch, V.-H., and Zerefos, C.: Comparison of OMI NO2 tropospheric columns with an ensemble of global and European regional air quality models, Atmos. Chem. Phys., 10, 3273-3296, doi:10.5194/acp-10-3273-2010, 2010.

Iqbal, M.: An introduction to solar radiation, Acadamec Press, Ontario, 1983.

Isaksen, I. and Hov, Ø.: Calculation of trends in the tropospheric concentration of $\mathrm{O}_{3}, \mathrm{OH}, \mathrm{CO}, \mathrm{CH}_{4}$ and $\mathrm{NO}_{\mathrm{x}}$, Tellus, 39B, 271285, 1987.

Iversen, T.: Calculations of long-range transported sulphur and nitrogen over Europe, Sci. Total Environ., 96, 87-99, 1990.

Janach, W.: Surface ozone: trend details, seasonal variations, and interpretation, J. Geophys. Res., 94, 18289-18295, 1989.

Jarvis, P., James, G., and Landsberg, J.: Coniferous forest, in: Vegetation and the Atmosphere, edited by: Monteith, J., vol. 2, 171240, Academic Press, 1976.

Jenkin, M. E., Watson, L. A., Utembe, S. R., and Shallcross, D. E.: A Common Representative Intermediates (CRI) mechanism for VOC degradation. Part 1: Gas phase mechanism development, Atmos. Environ., 42, 7185-7195, doi:10.1016/j.atmosenv.2008.07.028, 2008.

Jeričevič, A., Kraljević, L., Grisogono, B., Fagerli, H., and Večenaj, Ž.: Parameterization of vertical diffusion and the atmospheric boundary layer height determination in the EMEP model, Atmos. Chem. Phys., 10, 341-364, doi:10.5194/acp-10-341-2010, 2010.

Johansson, C. and Granat, L.: An experimental-study of the dry deposition of gaseous nitric-acid to snow, Atmos. Environ., 20, 1165-1170, 1986.

Jonson, J., Jakobsen, H., and Berge, E.: Status of the development of the regional scale photo-chemical multi-layer Eulerian model, Norwegian Meteorological Institute, EMEP MSC-W Note 2/97, 1997.

Jonson, J., Kylling, A., Berntsen, T., Isaksen, I., Zerefos, C., and Kourtidis, K.: Chemical effects of UV fluctuations inferred from total ozone and tropospheric aerosol variations, J. Geophys. Res., 105, 14561-14574, 2000.

Jonson, J., Sundet, J., and L.Tarrasón: Model calculations of present and future levels of ozone and ozone precursors with a global and a regional model., Atmos. Environ., 35, 525-537, 2001.

Jonson, J. E., Simpson, D., Fagerli, H., and Solberg, S.: Can we explain the trends in European ozone levels?, Atmos. Chem. Phys., 6, 51-66, doi:10.5194/acp-6-51-2006, 2006a.

Jonson, J., Wind, P., Gauss, M., Tsyro, S., Søvde, A., Klein, H., Isaksen, I., and Tarrasón, L.: First results from the hemispheric EMEP model and comparison with the global Oslo CTM2 model, EMEP/MSC-W Technical Report 2/2006, 2006b.

Jonson, J., Tarrasón, L., Wind, P., Gauss, M., Valiyaveetil, S., Tsyro, S., Klein, H., Isaksen, I., and Benedictow, A.: First evaluation of the global EMEP model with comparison with the global Oslo CTM2 model, EMEP/MSC-W Technical Report 2/2007, 2007.

Jonson, J., Tarrasón, L., Klein, H., Vestreng, V., Cofala, J., and Whall, C.: Effects of ship emissions on European ground level ozone in 2020, Int. J. Remote Sens., 30, 4099-4110, doi:10.1080/01431160902821858, 2009.

Jonson, J. E., Stohl, A., Fiore, A. M., Hess, P., Szopa, S., Wild, O., Zeng, G., Dentener, F. J., Lupu, A., Schultz, M. G., Duncan, B. N., Sudo, K., Wind, P., Schulz, M., Marmer, E., Cuvelier, C., Keating, T., Zuber, A., Valdebenito, Á., Dorokhov, V., De Backer, H., Davies, J., Chen, G. H., Johnson, B., Tarasick, D. W., Stübi, R., Newchurch, M. J., von der Gathen, P., Steinbrecht, W., and Claude, H.: A multi-model analysis of vertical ozone profiles, Atmos. Chem. Phys., 10, 5759-5783, doi:10.5194/acp-10-57592010, 2010a.

Jonson, J. E., Tarrasón, L., Sundet, J., Berntsen, T., and Unger, S.: The Eulerian 3-D oxidant model: Status and evaluation for summer 1996 results and case-studies, in: EMEP MSC-W Report 2/98. Transboundary photo-oxidant air pollution in Europe, 31-56, The Norwegian Meteorological Institute, Oslo, Norway, 1998.

Jonson, J. E., Travnikov, O., Dastoor, A., Gauss, M., Hollander, A., Iyin, I., Lin, C.-J., MacLeod, M., Shatalov, V., Sokovykh, V., Valdebenito, Á., Valiyaveetil, S., and Wind, P.: Development of the EMEP global modelling framework: Progress report, Joint MSC-W/MSC-E Report 1/2010, Meteorological Synthesizing Centre - East (MSC-E), Moscow, Russia, 2010b.

Jonson, J. E., Valiyaveetil, S., Wind, P., Valdebenito, Á., and Gauss, M.: Model validation of the global version of the EMEP Unifed model, in: Development of the EMEP global modelling framework: Progress report, Joint MSC-W/MSC-E Report, EMEP/MSC-W Technical Report 1/2010, 14-31, The Norwegian Meteorological Institute, Oslo, Norway, 2010c.

Karl, M., Guenther, A., Köble, R., Leip, A., and Seufert, G.: A new European plant-specific emission inventory of biogenic volatile organic compounds for use in atmospheric transport models, Biogeosciences, 6, 1059-1087, doi:10.5194/bg-6-1059-2009, 2009.

Kesik, M., Ambus, P., Baritz, R., Brüggemann, N., ButterbachBahl, K., Damm, M., Duyzer, J., Horváth, L., Kiese, R., Kitzler, B., Leip, A., Li, C., Pihlatie, M., Pilegaard, K., Seufert, S., Simpson, D., Skiba, U., Smiatek, G., Vesala, T., and ZechmeisterBoltenstern, $\mathrm{S}$.: Inventories of $\mathrm{N}_{2} \mathrm{O}$ and $\mathrm{NO}$ emissions from $\mathrm{Eu}-$ ropean forest soils, Biogeosciences, 2, 353-375, doi:10.5194/bg2-353-2005, 2005.

Klingberg, J., Danielsson, H., Simpson, D., and Pleijel, H.: Comparison of modelled and measured ozone concentrations and meteorology for a site in south-west Sweden: Implications for ozone uptake calculations, Environ. Poll., 115, 99-111, 2008. 
Köble, R. and Seufert, G.: Novel Maps for Forest Tree Species in Europe, in: A Changing Atmosphere, 8th European Symposium on the Physico-Chemical Behaviour of Atmospheric Pollutants, Torino, Italy, 17-20 September, 2001, http://ies.jrc.ec.europa.eu/Units/cc/events/torino2001/torinocd/ Documents/Terrestrial/TP35.htm, 2001.

Köhler, I., Sausen, R., and Klenner, G.: $\mathrm{NO}_{\mathrm{x}}$ production from lightning, The impact of $\mathrm{NO}_{\mathrm{x}}$ emissions from aircraft upon the atmosphere at flight altitudes $8-15 \mathrm{~km}$ (AERONOX), edited by: Schumann, U., final report to the Commission of the European Communities, Deutch Luft und Raumfart, Oberpfaffenhofen, Germany, 1995.

Kuhn, M., Builtjes, P., Poppe, D., Simpson, D., Stockwell, W., Andersson-Sköld, Y., Baart, A., Das, M., Fiedler, F., Hov, Ø., Kirchner, F., Makar, P., Milford, J., Roemer, M., Ruhnke, R., Strand, A., Vogel, B., and Vogel, H.: Intercomparison of the gasphase chemistry in several chemistry and transport models, Atmos. Environ., 32, 693-709, 1998.

Kulmala, M., Asmi, A., Lappalainen, H. K., Baltensperger, U., Brenguier, J.-L., Facchini, M. C., Hansson, H.-C., Hov, Ø., O'Dowd, C. D., Pöschl, U., Wiedensohler, A., Boers, R., Boucher, O., de Leeuw, G., Denier van der Gon, H. A. C., Feichter, J., Krejci, R., Laj, P., Lihavainen, H., Lohmann, U., McFiggans, G., Mentel, T., Pilinis, C., Riipinen, I., Schulz, M., Stohl, A., Swietlicki, E., Vignati, E., Alves, C., Amann, M., Ammann, M., Arabas, S., Artaxo, P., Baars, H., Beddows, D. C. S., Bergström, R., Beukes, J. P., Bilde, M., Burkhart, J. F., Canonaco, F., Clegg, S. L., Coe, H., Crumeyrolle, S., D'Anna, B., Decesari, S., Gilardoni, S., Fischer, M., Fjaeraa, A. M., Fountoukis, C., George, C., Gomes, L., Halloran, P., Hamburger, T., Harrison, R. M., Herrmann, H., Hoffmann, T., Hoose, C., Hu, M., Hyvärinen, A., Hõrrak, U., Iinuma, Y., Iversen, T., Josipovic, M., Kanakidou, M., Kiendler-Scharr, A., Kirkevåg, A., Kiss, G., Klimont, Z., Kolmonen, P., Komppula, M., Kristjánsson, J.-E., Laakso, L., Laaksonen, A., Labonnote, L., Lanz, V. A., Lehtinen, K. E. J., Rizzo, L. V., Makkonen, R., Manninen, H. E., McMeeking, G., Merikanto, J., Minikin, A., Mirme, S., Morgan, W. T., Nemitz, E., O'Donnell, D., Panwar, T. S., Pawlowska, H., Petzold, A., Pienaar, J. J., Pio, C., Plass-Duelmer, C., Prévôt, A. S. H., Pryor, S., Reddington, C. L., Roberts, G., Rosenfeld, D., Schwarz, J., Seland, Ø., Sellegri, K., Shen, X. J., Shiraiwa, M., Siebert, H., Sierau, B., Simpson, D., Sun, J. Y., Topping, D., Tunved, P., Vaattovaara, P., Vakkari, V., Veefkind, J. P., Visschedijk, A., Vuollekoski, H., Vuolo, R., Wehner, B., Wildt, J., Woodward, S., Worsnop, D. R., van Zadelhoff, G.-J., Zardini, A. A., Zhang, K., van Zyl, P. G., Kerminen, V.-M., Carslaw, K., and Pandis, S. N.: General overview: European Integrated project on Aerosol Cloud Climate and Air Quality interactions (EUCAARI) - integrating aerosol research from nano to global scales, Atmos. Chem. Phys., 11, 13061-13143, doi:10.5194/acp11-13061-2011, 2011.

Kupiainen, K. and Klimont, Z.: Primary emissions of fine carbonaceous particles in Europe, Atmos. Environ., 41, 2156-2170, doi:10.1016/j.atmosenv.2006.10.066, 2007.

Kylling, A., Bais, A. F., Blumthaler, M., Schreder, J., Zerefos, C. S., and Kosmidis, E.: Effect of aerosols on solar UV irradiances during the Photochemical Activity and Solar Radiation campaign, J. Geophys. Res., 103, 26051-26060, doi:10.1029/98JD02350, 1998.
Laakso, L., Gronholm, T., Rannik, U., Kosmale, M., Fiedler, V., Vehkamaki, H., and Kulmala, M.: Ultrafine particle scavenging coefficients calculated from 6 years field measurements, Atmos. Environ., 37, 3605-3613, 2003.

Lamaud, E., Brunet, Y., Labatut, A., Lopez, A., Fontan, J., and Druilhet, A.: The Landes experiment: Biosphere-atmosphere exchanges of ozone and aerosol particles above a pine forest, J. Geophys. Res., 99, 16511-16521, doi:10.1029/94JD00668, 1994.

Lane, T. E., Donahue, N. M., and Pandis, S. N.: Simulating secondary organic aerosol formation using the volatility basis-set approach in a chemical transport model, Atmos. Environ., 42, 7439-7451, doi:10.1016/j.atmosenv.2008.06.026, 2008.

Langner, J., Engardt, M., Baklanov, A., Christensen, J. H., Gauss, M., Geels, C., Hedegaard, G. B., Nuterman, R., Simpson, D., Soares, J., Sofiev, M., Wind, P., and Zakey, A.: A multi-model study of impacts of climate change on surface ozone in Europe, Atmos. Chem. Phys. Discuss., 12, 4901-4939, doi:10.5194/acpd-12-4901-2012, http://www. atmos-chem-phys-discuss.net/12/4901/2012/, 2012.

Laville, P., Henault, C., Gabrielle, B., and Serca, D.: Measurement and modelling of NO fluxes on maize and wheat crops during their growing seasons: effect of crop management, Nutr. Cycl. Agroecosys., 72, 159-171, doi:10.1007/s10705-005-05105,2005

Laville, P., Flura, D., Gabrielle, B., Loubet, B., Fanucci, O., Rolland, M. N., and Cellier, P.: Characterisation of soil emissions of nitric oxide at field and laboratory scale using high resolution method, Atmos. Environ., 43, 2648-2658, doi:10.1016/j.atmosenv.2009.01.043, 2009.

Lenschow, H. S. and Tsyro, S.: Meteorological input data for EMEP/MSC-W air pollution models, EMEP MSC-W Note 2/2000, The Norwegian Meteorological Institute, Oslo, Norway, 2000.

Lewis, A. C., Hopkins, J. R., Carpenter, L. J., Stanton, J., Read, K. A., and Pilling, M. J.: Sources and sinks of acetone, methanol, and acetaldehyde in North Atlantic marine air, Atmos. Chem. Phys., 5, 1963-1974, doi:10.5194/acp-5-1963-2005, 2005.

Li, Z. and Aneja, V.: Regional analysis of cloud chemistry at high elevations in the Eastern United States, Atmos. Environ., 26A, 2001-2017, 1992.

Linn, D. and Doran, J.: Effect of water-filled pore-space on carbondioxide and nitrous-oxide production in tilled and nontilled soils, Soil Sci. Soc. Am. J., 48, 1267-1272, 1984.

Liu, X., Easter, R. C., Ghan, S. J., Zaveri, R., Rasch, P., Shi, X., Lamarque, J.-F., Gettelman, A., Morrison, H., Vitt, F., Conley, A., Park, S., Neale, R., Hannay, C., Ekman, A. M. L., Hess, P., Mahowald, N., Collins, W., Iacono, M. J., Bretherton, C. S., Flanner, M. G., and Mitchell, D.: Toward a minimal representation of aerosols in climate models: description and evaluation in the Community Atmosphere Model CAM5, Geosci. Model Dev., 5, 709-739, doi:10.5194/gmd-5-709-2012, 2012.

Logan, J.: Trends in the vertical distribution of ozone: An analysis of ozonesonde data, J. Geophys. Res., 99, 25553-25585, 1994.

Logan, J. A.: An analysis of ozonesonde data for the troposphere: Recommendations for testing 3-D models and development of a gridded climatology for troposheric ozone, J. Geophys. Res., 10, 16115-16149, 1998. 
Low, P., Davies, T., Kelly, P., and Farmer, G.: Trends in surface ozone at Hohenpeissenberg and Arkona, J. Geophys. Res., 95, 22441-22453, 1990.

LRTAP: Mapping critical levels for vegetation, in: Manual on Methodologies and Criteria for Mapping Critical Loads and Levels and Air Pollution Effects, Risks and Trends. Revision of 2009, edited by Mills, G., UNECE Convention on Longrange Transboundary Air Pollution, International Cooperative Programme on Effects of Air Pollution on Natural Vegetation and Crops, updated version available at: http://www.rivm.nl/en/ themasites/icpmm, 2009.

Mareckova, K., Wankmüller, R., Wiesser, M., Poupa, S., Anderl, M., and Muik, B.: Inventory review 2009. Emission data reported under the LRTAP Convention and NEC Directive. Stage 1 and 2 review. Status of gridded data, EMEP/CEIP Technical Report 1/2009, EEA/CEIP Vienna, 2009.

Mårtensson, E., Nilsson, E., de Leeuw, G., Cohen, L., and Hansson, H.-C.: Laboratory simulations and parameterisation of the primary marine aerosol production, J. Geophys. Res., 108, 4297, doi:10.1029/2002JD002263, 2003.

Marticorena, B. and Bergametti, G.: Modelling the atmospheric dust cycle: 1. Design of a soil drived dust emission scheme., J. Geophys. Res., 100, 16415-16430, doi:10.1029/95jd00690, 1995.

Marticorena, B., Bergametti, G., Aumont, B., Callot, Y., N'Doumé, C., and Legrand, M.: Modelling the atmospheric dust cycle: 2. Simulation of Saharan dust sources, J. Geophys. Res., 102, 43874404, 1997.

Martin, L. R. and Damschen, D. E.: Aqueous oxidation of sulphur dioxide by hydrogen peroxide at low p, Atmos. Environ., 15, 1615-1621, 1981.

Mason, P.: The formation of areally-averaged roughness lengths, Q. J. Roy. Meteorol. Soc., 114, 399-420, 1988.

Massad, R.-S., Nemitz, E., and Sutton, M. A.: Review and parameterisation of bi-directional ammonia exchange between vegetation and the atmosphere, Atmos. Chem. Phys., 10, 10359-10386, doi:10.5194/acp-10-10359-2010, 2010.

Mastin, L. G., Guffanti, M., Ewert, J. E., and Spiegel, J.: Preliminary spreadsheet of eruption source parameters for volcanoes of the world, Open-File Report 2009-1133, U.S. Geological Survey, http://pubs.usgs.gov/of/2009/1133/, 2009a.

Mastin, L. G., Guffanti, M., Servranckx, R., Webley, P., Barsotti, S., Dean, K., Durant, A., Ewert, J. W., Neri, A., Rose, W. I., Schneider, D., Siebert, L., Stunder, B., Swanson, G., Tupper, A., Volentik, A., and Waythomas, C. F.: A multidisciplinary effort to assign realistic source parameters to models of volcanic ash-cloud transport and dispersion during eruptions, J. Volcanol. Geotherm. Res., 186, 10-21, doi:10.1016/j.jvolgeores.2009.01.008, 2009b.

Mentel, T. F., Sohn, M., and Wahner, A.: Nitrate effect in the heterogeneous hydrolysis of dinitrogen pentoxide on aqueous aerosols, Phys. Chem. Chem. Phys., 1, 5451-5457, 1999.

Menut, L., Goussebaile, A., Bessagnet, B., Khvorostiyanov, D., and Ung, A.: Impact of realistic hourly emissions profiles on air pollutants concentrations modelled with CHIMERE, Atmos. Environ., 49, 233-244, doi:10.1016/j.atmosenv.2011.11.057, 2012.

Metzger, S.: Gas/Aerosol partitioning: a simplified method for global modelling, Ph.D. thesis, University Utrecht, 2000.

Metzger, S. M., Dentener, F. J., Lelieveld, J., and Pandis, S. N.: Gas/Aerosol Partitioning 1. A computionally efficient model., J.
Geophys. Res., 107, ACH 16, doi:10.1029/2001JD001102, 2002.

Miller, G. R., Baldocchi, D. D., Law, B. E., and Meyers, T.: An analysis of soil moisture dynamics using multi-year data from a network of micrometeorological observation sites, Adv. Water Resour., 30, 1065-1081, doi:10.1016/j.advwatres.2006.10.002, 2007.

Millet, D. B., Guenther, A., Siegel, D. A., Nelson, N. B., Singh, H. B., de Gouw, J. A., Warneke, C., Williams, J., Eerdekens, G., Sinha, V., Karl, T., Flocke, F., Apel, E., Riemer, D. D., Palmer, P. I., and Barkley, M.: Global atmospheric budget of acetaldehyde: 3-D model analysis and constraints from in-situ and satellite observations, Atmos. Chem. Phys., 10, 3405-3425, doi:10.5194/acp-10-3405-2010, 2010.

Mills, G., Hayes, F., Simpson, D., Emberson, L., Norris, D., Harmens, H., and Büker, P.: Evidence of widespread effects of ozone on crops and (semi-)natural vegetation in $\mathrm{Eu}-$ rope (1990-2006) in relation to AOT40- and flux-based risk maps, Glob. Change Biol., 17, 592-613, doi:10.1111/j.13652486.2010.02217.x, 2011a.

Mills, G., Pleijel, H., Braun, S., Büker, P., Bermejo, V., Calvo, E., Danielsson, H., Emberson, L., Grünhage, L., Fernández, I. G., Harmens, H., Hayes, F., Karlsson, P.-E., and Simpson, D.: New stomatal flux-based critical levels for ozone effects on vegetation, Atmos. Environ., 45, 5064-5068, doi:10.1016/j.atmosenv.2011.06.009, 2011 b.

Möller, D.: Kinetic model of atmospheric $\mathrm{SO}_{2}$ oxidation based on published dat, Atmos. Environ., 14, 1067-1076, 1980.

Monahan, E., Spiel, D., and Davidson, K.: A model of marine aerosol generation via white caps and wave disruption, in: Oceanic whitecaps, edited by: Monahan, E. and MacNiochaill, G., 167-193, Dordrecht: Reidel, The Netherlands, 1986.

Monks, P., Granier, C., Fuzzi, S., Stohl, A., Williams, M., Akimoto, H., Amman, M., Baklanov, A., Baltensperger, U., Bey, I., Blake, N., Blake, R., Carslaw, K., Cooper, O., Dentener, F., Fowler, D., Fragkou, E., Frost, G., Generoso, S., Ginoux, P., Grewe, V., Guenther, A., Hansson, H., Henne, S., Hjorth, J., Hofzumahaus, A., Huntrieser, H., Isaksen, I., Jenkin, M., Kaiser, J., Kanakidou, M., Klimont, Z., Kulmala, M., Laj, P., Lawrence, M., Lee, J., Liousse, C., Maione, M., McFiggans, G., Metzger, A., Mieville, A., Moussiopoulos, N., Orlando, J., O’Dowd, C., Palmer, P., Parrish, D., Petzold, A., Platt, U., Poeschl, U., Prévôt, A., Reeves, C., Reimann, S., Rudich, Y., Sellegri, K., Steinbrecher, R., Simpson, D., ten Brink, H., Theloke, J., van der Werf, G., Vautard, R., Vestreng, V., Vlachokostas, C., and vonGlasow, R.: Atmospheric Composition Change - Global and Regional Air Quality, Atmos. Environ., 43, 5268-5350, doi:10.1016/j.atmosenv.2009.08.021, 2009.

Nemitz, E., Milford, C., and Sutton, M. A.: A two-level canopy compensation point model for describing bi-directional biosphere-atmosphere exchange of ammonia, Q. J. Roy. Meteorol. Soc., 127, 815-833, 2001.

Nemitz, E., Sutton, M. A., Wyers, G. P., Otjes, R. P., Mennen, M. G., van Putten, E. M., and Gallagher, M. W.: Gas-particle interactions above a Dutch heathland: II. Concentrations and surface exchange fluxes of atmospheric particles, Atmos. Chem. Phys., 4, 1007-1024, doi:10.5194/acp-4-1007-2004, 2004.

Ng, N. L., Canagaratna, M. R., Zhang, Q., Jimenez, J. L., Tian, J., Ulbrich, I. M., Kroll, J. H., Docherty, K. S., Chhabra, P. S., Bahreini, R., Murphy, S. M., Seinfeld, J. H., Hildebrandt, L., 
Donahue, N. M., DeCarlo, P. F., Lanz, V. A., Prevot, A. S. H., Dinar, E., Rudich, Y., and Worsnop, D. R.: Organic aerosol components observed in Northern Hemispheric datasets from Aerosol Mass Spectrometry, Atmos. Chem. Physics, 10, 46254641, doi:10.5194/acp-10-4625-2010, 2010.

Norman, J.: Modeling the complete crop canopy, 249-277, Am. Soc. Agric. Engr. St. Joseph, MI, 1979.

Norman, J.: Simulation of microclimates, 65-99, Academic Press, New York, USA, 1982.

O'Brien, J. J.: A Note on the vertical structure of the eddy exchange coefficient in the planetary boundary layer, J. Atmos. Sci., 27, 1213-1215, 1970.

Pakkanen, T. A., Kerminen, V. M., Hillamo, R. E., Makinen, M., Makela, T., and Virkkula, A.: Distribution of nitrate over sea-salt and soil derived particles - Implications from a field study, J. Atmos. Chem., 24, 189-205, 1996.

Papale, D., Reichstein, M., Aubinet, M., Canfora, E., Bernhofer, C., Kutsch, W., Longdoz, B., Rambal, S., Valentini, R., Vesala, T., and Yakir, D.: Towards a standardized processing of Net Ecosystem Exchange measured with eddy covariance technique: algorithms and uncertainty estimation, Biogeosciences, 3, 571-583, doi:10.5194/bg-3-571-2006, 2006.

Passant, N.: Speciation of UK emissions of non-methane volatile organic compounds, Report ENV-0545 ENV-0545, 2002.

Penkett, S., Blake, N., Lightman, P., Marsh, A., Anwyl, P., and Butcher, G.: The seasonal variation of nonmethane hydrocarbons in the free troposphere over the North Atlantic ocean: possible evidence for extensive reaction of hydrocarbons with the nitrate radical, J. Geophys. Res., 98, 2865-2885, 1993.

Petroff, A., Mailliat, A., Amielh, M., and Anselmet, F.: Aerosol dry deposition on vegetative canopies. Part I: Review of present knowledge, Atmos. Environ., 42, 3625-3653, doi:10.1016/j.atmosenv.2007.09.043, 2008a.

Petroff, A., Mailliat, A., Amielh, M., and Anselmet, F.: Aerosol dry deposition on vegetative canopies. Part II: A new modelling approach and applications, Atmos. Environ., 42, 3654-3683, doi:10.1016/j.atmosenv.2007.12.060, 2008b.

Pielke, R.: Mesoscale meteorological modelling. Second Edition, Academic Press, 2002.

Pierce, T. and Waldruff, P.: PC-BEIS: a personal computer version of the biogenic emissions inventory system, J. Air Waste Manage. Assoc., 41, 937-941, 1991.

Pilegaard, K., Skiba, U., Ambus, P., Beier, C., Brüggemann, N., Butterbach-Bahl, K., Dick, J., Dorsey, J., Duyzer, J., Gallagher, M., Gasche, R., Horvath, L., Kitzler, B., Leip, A., Pihlatie, M. K., Rosenkranz, P., Seufert, G., Vesala, T., Westrate, H., and Zechmeister-Boltenstern, S.: Factors controlling regional differences in forest soil emission of nitrogen oxides ( $\mathrm{NO}$ and $\mathrm{N}_{2} \mathrm{O}$ ), Biogeosciences, 3, 651-661, doi:10.5194/bg-3-651-2006, 2006.

Posch, M., Slootweg, J., and J.-P. H. (Eds.): European critical loads and dynamic modelling: CCE Status Report 2005, Mnp report 259101016, Coordination Centre for Effects, RIVM, Bilthoven, Netherlands, www.rivm.nl/cce, 2005.

Pregger, T. and Friedrich, R.: Effective pollutant emission heights for atmospheric transport modelling based on real-world information, Environ. Poll., 157, 552-560, doi:10.1016/j.envpol.2008.09.027, 2009.

Pryor, S. C., Barthelmie, R. J., Sorensen, L. L., Larsen, S. E., Sempreviva, A. M., Gronholm, T., Rannik, U., Kulmala,
M., and Vesala, T.: Upward fluxes of particles over forests: when, where, why?, Tellus, 60, 372-380, doi:10.1111/j.16000889.2008.00341.x, 2008a.

Pryor, S. C., Gallagher, M., Sievering, H., Larsen, S. E., Barthelmie, R. J., Birsan, F., Nemitz, E., Rinne, J., Kulmala, M., Groenholm, T., Taipale, R., and Vesala, T.: A review of measurement and modelling results of particle atmosphere-surface exchange, Tellus, 60, 42-75, doi:10.1111/j.1600-0889.2007.00298.x, 2008b.

Reis, S., Simpson, D., Friedrich, R., Jonson, J., Unger, S., and Obermeier, A.: Road traffic emissions - predictions of future contributions to regional ozone levels in Europe, Atmos. Environ., 34, 4701-4710, 2000.

Riemer, N., Vogel, H., Vogel, B., Schell, B., Ackermann, I., Kessler, C., and Hass, H.: Impact of the heteorogenous hydrolysis of $\mathrm{N}_{2} \mathrm{O}_{5}$ on chemistry and nitrate formation in the lower troposhere under photosmog conditions, J. Geophys. Res., 108, 4144, 10.1029/2002JD002436,

Riemer, N., Vogel, H., Vogel, B., Anttila, T., Kiendler-Scharr, A., and Mentel, T. F.: Relative importance of organic coatings for the heterogeneous hydrolysis of $\mathrm{N}_{2} \mathrm{O}_{5}$ during summer in Europe, J. Geophys. Res., 114, D17307, 10.1029/2008JD011369 2009.

Robertson, L., Langner, J., and Engardt, M.: An Eulerian limitedarea atmospheric transport model, J. Appl. Met., 38, 190-210, 1999.

Robinson, A. L., Donahue, N. M., Shrivastava, M. K., Weitkamp, E. A., Sage, A. M., Grieshop, A. P., Lane, T. E., Pierce, J. R., and Pandis, S. N.: Rethinking Organic Aerosols: Semivolatile Emissions and Photochemical Aging, Science, 315, 1259-1262, doi:10.1126/science.1133061, 2007.

Rolland, M. N., Gabrielle, B., Laville, P., Serca, D., Cortinovis, J., Larmanou, E., Lehuger, S., and Cellier, P.: Modeling of nitric oxide emissions from temperate agricultural soils, Nutr. Cycl Agroecosys., 80, 75-93, doi:10.1007/s10705-007-9122-6, 2008.

Rolland, M. N., Gabrielle, B., Laville, P., Cellier, P., Beekmann, M., Gilliot, J. M., Michelin, J., Hadjar, D., and Curci, G.: Highresolution inventory of $\mathrm{NO}$ emissions from agricultural soils over the Ile-de-France region, Environ. Poll., 158, 711-722, doi:10.1016/j.envpol.2009.10.017, 2010.

Salzen, K. V., Claussen, M., and Schlunzen, K.: Application of the Concept of Blending Height to the Calculation of Surface Fluxes in a Mesoscale Model, Meteorol. Zeitschrift, 5, 60-66, 1996.

Schaufler, G., Kitzler, B., Schindlbacher, A., Skiba, U., Sutton, M. A., and Zechmeister-Boltenstern, S.: Greenhouse gas emissions from European soils under different land use: effects of soil moisture and temperature, Eur. J. Soil Sci., 61, 683-696, doi:10.1111/j.1365-2389.2010.01277.x, 2010.

Scott, B. C.: Parameterization of sulphate removal by precipitation, J. Appl. Met., 17, 11375-11389, 1979.

Seibert, P., Beyrich, F., Gryning, S.-E., Joffre, S., Rasmussen, A., and Tercier, P.: Review and intercomparison of operational methods for the determination of the mixing height, Atmos. Environ., 34, 1001-1027, 2000.

Seinfeld, J. and Pandis, S.: Atmospheric chemistry and physics. From air pollution to climate change, John Wiley and Sons, Inc., New York, USA, 1998.

Shapiro, R.: Smoothing, filtering and boundary effects., Rev. Geophys. Space Phys., 8, 359-387, 1970.

Shrivastava, M. K., Lane, T. E., Donahue, N. M., Pandis, S. N., and Robinson, A. L.: Effects of gas particle partitioning 
and aging of primary emissions on urban and regional organic aerosol concentrations, J. Geophys. Res., 113, D18301, doi:10.1029/2007JD009735, 2008.

Simpson, D.: Long period modelling of photochemical oxidants in Europe. Calculations for July 1985, Atmos. Environ., 26A, 1609-1634, 1992.

Simpson, D.: Photochemical model calculations over Europe for two extended summer periods: 1985 and 1989, Model results and comparisons with observations, Atmos. Environ., 27A, 921-943, 1993.

Simpson, D.: Biogenic emissions in Europe 2: Implications for ozone control strategies, J. Geophys. Res., 100, 22891-22906, 1995.

Simpson, D., Andersson-Sköld, Y., and Jenkin, M. E.: Updating the chemical scheme for the EMEP MSC-W oxidant model : current status, EMEP MSC-W Note 2/93, The Norwegian Meteorological Institute, Oslo, Norway, 1993.

Simpson, D., Guenther, A., Hewitt, C., and Steinbrecher, R.: Biogenic emissions in Europe 1. Estimates and uncertainties, J. Geophys. Res., 100, 22875-22890, 1995.

Simpson, D., Winiwarter, W., Börjesson, G., Cinderby, S., Ferreiro, A., Guenther, A., Hewitt, C. N., Janson, R., Khalil, M. A. K., Owen, S., Pierce, T. E., Puxbaum, H., Shearer, M., Skiba, U., Steinbrecher, R., Tarrasón, L., and Öquist, M. G.: Inventorying emissions from Nature in Europe, J. Geophys. Res., 104, 81138152, 1999.

Simpson, D., Tuovinen, J.-P., Emberson, L., and Ashmore, M.: Characteristics of an ozone deposition module, Water Air Soil Pollut.: Focus, 1, 253-262, 2001.

Simpson, D., Fagerli, H., Jonson, J., Tsyro, S., Wind, P., and Tuovinen, J.-P.: The EMEP Unified Eulerian Model. Model Description, EMEP MSC-W Report 1/2003, The Norwegian Meteorological Institute, Oslo, Norway, 2003a.

Simpson, D., Tuovinen, J.-P., Emberson, L., and Ashmore, M.: Characteristics of an ozone deposition module II: sensitivity analysis, Water Air Soil Pollut., 143, 123-137, 2003 b.

Simpson, D., Butterbach-Bahl, K., Fagerli, H., Kesik, M., Skiba, U., and Tang, S.: Deposition and Emissions of Reactive Nitrogen over European Forests: A Modelling Study, Atmos. Environ., 40, 5712-5726, doi:10.1016/j.atmosenv.2006.04.063, 2006a.

Simpson, D., Fagerli, H., Hellsten, S., Knulst, J. C., and Westling, O.: Comparison of modelled and monitored deposition fluxes of sulphur and nitrogen to ICP-forest sites in Europe, Biogeosciences, 3, 337-355, doi:10.5194/bg-3-337-2006, 2006 b.

Simpson, D., Emberson, L., Ashmore, M., and Tuovinen, J.: A comparison of two different approaches for mapping potential ozone damage to vegetation. A model study, Environ. Poll., 146, 715725, doi:10.1016/j.envpol.2006.04.013, 2007a.

Simpson, D., Yttri, K., Klimont, Z., Kupiainen, K., Caseiro, A., Gelencsér, A., Pio, C., and Legrand, M.: Modeling Carbonaceous Aerosol over Europe. Analysis of the CARBOSOL and EMEP EC/OC campaigns, J. Geophys. Res., 112, D23S14, doi:10.1029/2006JD008158, 2007b.

Singh, H. B., Salas, L. J., Chatfield, R. B., Czech, E., Fried, A., Walega, J., Evans, M. J., Field, B. D., Jacob, D. J., Blake, D., Heikes, B., Talbot, R., Sachse, G., Crawford, J. H., Avery, M. A., Sandholm, S., and Fuelberg, H.: Analysis of the atmospheric distribution, sources, and sinks of oxygenated volatile organic chemicals based on measurements over the
Pacific during TRACE-P, J. Geophys. Res., 109, D15S07, doi:10.1029/2003JD003883, 2004.

Skamarock, W. C. and Klemp, J. B.: A time-split nonhydrostatic atmospheric model for weather research and forecasting applications, J. Comp. Phys., 227, 3465-3485, doi:10.1016/j.jcp.2007.01.037, 2008.

Skålin, R., Lie, I., and Berge, E.: A parallel algorithm for simulation of long range transport of air pollution, in: High performance computing in the geosciences, edited by: Dimet, F.-X. L., 175185, Kluwer Academic Publishers, 1995.

Slinn, W. G. N.: Predictions for particle deposition to vegetative canopies, Atmos. Environ., 16, 1785-1794, 1982.

Smith, R., Fowler, D., Sutton, M. A., Flechard, C., and Coyle, M.: Regional estimation of pollutant gas dry deposition in the UK: model description, sensitivity analyses and outputs, Atmos. Environ., 34, 3757-3777, 2000.

Smith, R., Fowler, D., and Sutton, M. A.: The external surface resistance in the EMEP Eulerian model, Technical note to EMEP MSC-W, 2003.

Sofiev, M., Vankevich, R., Lotjonen, M., Prank, M., Petukhov, V., Ermakova, T., Koskinen, J., and Kukkonen, J.: An operational system for the assimilation of the satellite information on wildland fires for the needs of air quality modelling and forecasting, Atmos. Chem. Phys., 9, 6833-6847, doi:10.5194/acp-9-68332009, 2009.

Solberg, S., Dye, C., Schmidbauer, N., Herzog, A., and Gehrig, R.: Carbonyls and nonmethane hydrocarbons at rural European sites from the Mediterranean to the Arctic, J. Atmos. Chem., 25, 3366, 1996.

Solberg, S., Dye, C., Walker, S., and Simpson, D.: Long-term measurements and model calculations of formaldehyde at rural European monitoring sites, Atmos. Environ., 35, 195-207, 2001.

Stevenson, D., Dentener, F., Schultz, M., Ellingsen, K., van Noije, T., Wild, O., Zeng, G., Amann, M., Atherton, C., Bell, N., Bergmann, D., Bey, I., Butler, T., Cofala, J., Collins, W., Derwent, R., Doherty, R., Drevet, J., Eskes, H., Fiore, A., Gauss, M., Hauglustaine, D., Horowitz, L., Isaksen, I., Krol, M., Lamarque, J., Lawrence, M., Montanaro, V., Muller, J., Pitari, G., Prather, M., Pyle, J., Rast, S., Rodriguez, J., Sanderson, M., Savage, N., Shindell, D., Strahan, S., Sudo, K., and Szopa, S.: Multimodel ensemble simulations of present-day and nearfuture tropospheric ozone, J. Geophys. Res., 111, D08301, doi:10.1029/2005JD006338, 2006.

Stordal, F., Isaksen, I. S. A., and Horntveth, K.: A diabatic circulation two-dimensional model with photochemistry: simulations of ozone and long-lived tracers with surface sources, J. Geophys. Res., 90, 5757-5776, 1985.

Stull, R.: An introduction to Atmospheric Boundary Layer Meteorology, Kluwer Academic Publishers, Dordrecht, The Netherlands, 1988.

Sundet, J.: Model studies with a 3-d global CTM using ECMWF data, Ph.D. thesis, Department of Geophysics, University of Oslo, Norway, 1997.

Sutton, M. A., Nemitz, E., Milford, C., Fowler, D., Moreno, J., San Jose, R., Wyers, G. P., Otjes, R. P., Harrison, R., Husted, S., and Schjoerring, J. K.: Micrometeorological measurements of net ammonia fluxes over oilseed rape during two vegetation periods, Agr. Forest Meteorol., 105, 351-369, 2000. 
Tang, Y., Simmons, I., van Dijk, N., Marco, C. D., Nemitz, E., Dämmgen, U., Gilke, K., Djuricic, V., Vidic, S., Gliha, Z., Borovecki, D., Mitosinkova, M., Hanssen, J., Uggerud, T., Sanz, M., Sanz, P., Chorda, J., Flechard, C., Fauvel, Y., Ferm, M., Perrino, C., and Sutton, M.: European scale application of atmospheric reactive nitrogen measurements in a low-cost approach to infer dry deposition fluxes, Agr. Ecosyst. Environ., 133, 183195, doi:10.1016/j.agee.2009.04.027, 2009.

Tarrasón, L., Turner, S., and Floisand, I.: Estimation of seasonal dimethyl sulphide fluxes over the North Atlantic Ocean and their contribution to European pollution levels, J. Geophys. Res., 100, 11623-11639, 1995.

Tiedtke, M.: A Comprehensive Mass Flux Scheme For Cumulus Parameterization In Large-Scale Models, Mon. Weather Rev., 117, 1779-1800, 1989.

Torseth, K., Semb, A., Schaug, J., Hanssen, J., and Aamlid, D.: Processes affecting deposition of oxidised nitrogen and associated species in the coastal areas of Norway, Atmos. Environ., 34, 207-217, 2000.

Tørseth, K., Aas, W., Breivik, K., Fjæraa, A. M., Fiebig, M., Hjellbrekke, A. G., Lund Myhre, C., Solberg, S., and Yttri, K. E.: Introduction to the European Monitoring and Evaluation Programme (EMEP) and observed atmospheric composition change during 1972-2009, Atmos. Chem. Phys., 12, 5447-5481, doi:10.5194/acp-12-5447-2012, 2012.

Travnikov, O., Jonson, J. E., Andersen, A. S., Gauss, M., Gusev, A., Rozovskaya, O., Simpson, D., Sokovyh, V., Valiyaveetil, S., and Wind, P.: Development of the EMEP global modelling framework: Progress report, EMEP/MSC-E Technical Report 7/2009, Meteorological Synthesizing Centre - East (MSC-E), Moscow, Russia, 2009.

Tsyro, S. G.: To what extent can aerosol water explain the discrepancy between model calculated and gravimetric $\mathrm{PM}_{10}$ and $\mathrm{PM}_{2.5}$ ?, Atmos. Chem. Phys., 5, 515-532, doi:10.5194/acp-5515-2005, 2005.

Tsyro, S.: Regional Model for Formation, Dynamics, and Longrange Transport of Atmospheric Aerosol: Study of Atmospheric Aerosol Properties in Europe, Russ. Meteorol. Hydrol., 33, 300309, doi:10.3103/S106837390805004X, 2008.

Tsyro, S., Simpson, D., Tarrasón, L., Kupiainen, K., Klimont, Z., Yttri, K., and Pio, C.: Modelling of black carbon over Europe, J. Geophys. Res., 112, D23S19, doi:10.1029/2006JD008164, 2007.

Tsyro, S., Aas, W., Soares, J., Sofiev, M., Berge, H., and Spindler, G.: Modelling of sea salt concentrations over Europe: key uncertainties and comparison with observations, Atmos. Chem. Phys., 11, 10367-10388, doi:10.5194/acp-11-10367-2011, 2011.

Tuovinen, J.-P.: Assessing vegetation exposure to ozone: properties of the AOT40 index and modifications by deposition modelling, Environ. Poll., 109, 361-372, 2000.

Tuovinen, J.-P. and Simpson, D.: An aerodynamic correction for the European ozone risk assessment methodology, Atmos. Environ., 42, 8371-8381, doi:10.1016/j.atmosenv.2008.08.008, 2008.

Tuovinen, J.-P., Simpson, D., Mikkelsen, T., Emberson, L., M., M. R. A., Aurela, Cambridge, H. M., Hovmand, M. F., Jensen, N. O., Laurila, T., Pilegaard, K., and Ro-Poulsen, H.: Comparisons of measured and modelled ozone deposition to forests in Northern Europe, Water Air Soil Poll. Focus, 1, 263-274, 2001.

Tuovinen, J.-P., Ashmore, M., Emberson, L., and Simpson, D.: Testing and improving the EMEP ozone deposition module, Atmos.
Environ., 38, 2373-2385, 2004.

Tuovinen, J.-P., Emberson, L., and Simpson, D.: Modelling ozone fluxes to forests for risk assessment: status and prospects, Ann. For. Sci., 66, 401, doi:10.1051/forest/2009024, 2009.

Uddling, J., Pleijel, H., and Karlsson, P. E.: Measuring and modelling leaf diffusive conductance in juvenile silver birch, Betula pendula, Trees-Structure And Function, 18, 686-695, 2004.

UN-ECE: International Co-operative Programme on Assessment and Monitoring of Air Pollution Effects on Forests. Manual on methods and criteria for harmonized sampling, assessment, monitoring and analysis of the effects of air pollution on forests, http://icp-forests.net, 1998.

Undén, P., Rontu, L., Järvinen, H., Lynch, P., Calvo, J., Cats, G., Cuxart, J., Eerola, K., Fortelius, C., Garcia-Moya, A., Jones, C., Lenderink, G., McDonald, A., McGrath, R., Navascues, B., Nielsen, N., Ødegaard, V., Rodriguez, E., Rummukainen, M., Rõõm, R., Sattler, K., Sass, B., Savijärvi, H., B.W., S., Sigg, R., The, H., and Tijm, A.: HIRLAM-5 Scientic Documentation December 2002, http://hirlam.org/, 2002.

Valdebenito, Á. and Benedictow, A.: EMEP - Products, Quality and Background Information, MACC deliverable report D_R-ENS_1.2.4, Monitoring Atmospheric Composition and Climate (MACC) consortium, http://www.gmes-atmosphere.eu/ documents/deliverables/r-ens/dossiers/, 2011.

van der Gon, H. D., Visschedijk, A., Droge, R., Mulder, M., Johansson, C., and Klimont, Z.: A high resolution emission inventory of particulate elemental carbon and organic carbon for Europe in 2005, paper presented at 7th International Conference on Air Quality - Science and Application (Air Quality 2009), Istanbul, 24-27 March 2009, 2009.

van der Werf, G. R., Randerson, J. T., Giglio, L., Collatz, G. J., Mu, M., Kasibhatla, P. S., Morton, D. C., DeFries, R. S., Jin, Y., and van Leeuwen, T. T.: Global fire emissions and the contribution of deforestation, savanna, forest, agricultural, and peat fires (19972009), Atmos. Chem. Phys., 10, 11707-11735, doi:10.5194/acp10-11707-2010, 2010.

van Loon, M., Vautard, R., Schaap, M., Bergstrom, R., Bessagnet, B., Brandt, J., Builtjes, P., Christensen, J., Cuvelier, C., Graff, A., Jonson, J., Krol, M., Langner, J., Roberts, P., Rouil, L., Stern, R., Tarrason, L., Thunis, P., Vignati, E., White, L., and Wind, P.: Evaluation of long-term ozone simulations from seven regional air quality models and their ensemble, Atmos. Environ., 41, 2083-2097, 2007.

Venkatram, A. and Pleim, J.: The electrical analogy does not apply to modeling dry deposition of particles, Atmos. Environ., 33, 3075-3076, 1999.

Verwer, J. and Simpson, D.: Explicit methods for stiff ODEs from atmospheric chemistry, Appl. Numer. Math., 18, 413-430, 1995.

Verwer, J. G., Blom, J. G., and Hundsdorfer, W.: An implicit explicit approach for atmospheric transport-chemistry problems, Appl. Numer. Math., 20, 191-209, 1996.

Vidic, S.: Frequency distributions of effective plume height, Internal technical note, EMEP, 10 September 2002, Croatian Meteorological and Hydrological Service, Zagreb, Croatia, 2002.

Vieno, M., Dore, A. J., Wind, P., Marco, C. D., Nemitz, E., Phillips, G., Tarrason, L., and Sutton, M. A.: Application of the EMEP Unified Model to the UK with a horizontal resolution of $5 \times 5$ $\mathrm{km}^{2}$, in: Atmospheric Ammonia. Detecting Emissions Changes and Environmental Impacts, edited by Sutton, M. A., Reis, S. 
and Baker, S. M., 367-372, Springer, 2009.

Vieno, M., Dore, A. J., Stevenson, D. S., Doherty, R., Heal, M. R., Reis, S., Hallsworth, S., Tarrason, L., Wind, P., Fowler, D., Simpson, D., and Sutton, M. A.: Modelling surface ozone during the 2003 heat-wave in the UK, Atmos. Chem. Phys., 10, 7963-7978, doi:10.5194/acp-10-7963-2010, 2010.

Volz, A. and Kley, D.: Evaluation of the Montsouris series of ozone measurements made in the nineteenth century, Nature, 332, 240242,1988

Watson, L. A., Shallcross, D. E., Utembe, S. R., and Jenkin, M. E.: A Common Representative Intermediates (CRI) mechanism for VOC degradation. Part 2: Gas phase mechanism reduction, Atmos. Environ., 42, 7196-7204, doi:10.1016/j.atmosenv.2008.07.034, 2008.

Wesely, M.: Parameterization of surface resistances to gaseous dry deposition in regional scale numerical models, Atmos. Environ., 23, 1293-1304, 1989.

Wesely, M. L., Cook, D. R., Hart, R. L., and Speer, R. E.: Measurements and Parameterization of Particulate Sulfur Dry Deposition over Grass, J. Geophys. Res., 90, 2131-2143, 1985.

Wiedinmyer, C., Akagi, S. K., Yokelson, R. J., Emmons, L. K., AlSaadi, J. A., Orlando, J. J., and Soja, A. J.: The Fire INventory from NCAR (FINN): a high resolution global model to estimate the emissions from open burning, Geosci. Model Dev., 4, 625641, doi:10.5194/gmd-4-625-2011, 2011.

Willett, M. R., Bechtold, P., Williamson, D. L., Petch, J. C., Milton, S. F., and Woolnough, S. J.: Modelling suppressed and active convection: Comparisons between three global atmospheric models, Q. J. R. Meteorol. Soc., 134, 1881-1896, doi:10.1002/qj.317, http://dx.doi.org/10.1002/qj.317, 2008.

Wind, P., Tarrasón, L., Berge, E., Slørdal, L., Solberg, S., and Walker, S.-E.: Development of a modeling system able to link hemispheric-regional and local air pollution problems, EMEP MSC-W Note 5/2002, Norwegian Meteorological Institute, Oslo, Norway, 2002.

Winiwarter, W., Haberl, H., and Simpson, D.: On the boundary between man-made and natural emissions: Problems in defining European ecosystems, J. Geophys. Res., 104, 8153-8159, 1999.
Wolff, V., Trebs, I., Foken, T., and Meixner, F. X.: Exchange of reactive nitrogen compounds: concentrations and fluxes of total ammonium and total nitrate above a spruce canopy, Biogeosciences, 7, 1729-1744, doi:10.5194/bg-7-1729-2010, 2010.

Yarwood, G., Rao, S., Yocke, M., and Whitten, G.: Updates to the Carbon Bond chemical mechanism: CB05, Final report to the US EPA, RT-0400675, 8 December 2005, Yocke and Company, www.camx.com/Files/CB05_Final_Report_120805.aspx, 2005.

Zaehle, S., Ciais, P., Friend, A. D., and Prieur, V.: Carbon benefits of anthropogenic reactive nitrogen offset by nitrous oxide emissions, Nat. Geosci., 4, 601-605, doi:10.1038/ngeo1207, 2011.

Zander, R., Demoulin, P., and Ehhalt, D. H., and Schmidt, U.: Secular increase of the total vertical column abundance of methane derived from IR solar spectra recorded at the Jungfraujoch station, J. Geophys. Res., 94, 11029-11039, 1989a.

Zander, R., Demoulin, P., Ehhalt, D. H., Schmidt, U., and Rinsland, C.: Secular increase of the total vertical column abundance of carbon dioxide above central Europe since 1950, J. Geophys. Res., 94, 11021-11028, 1989b.

Zender, C., Bian, H., and Newman, D.: Mineral Dust Entrainmentand Deposition (DEAD) model: Description and 1990s dust climatology., J. Geophys. Res., 108, 4416-4437, doi:10.1029/2002jd002775, 2003.

Zhang, L., Gong, S., Padro, J., and Barrie, L.: A size-segregated particle dry deposition scheme for an atmospheric aerosol module, Atmos. Environ., 35, 549-560, 2001.

Zhang, L., Brook, J. R., and Vet, R.: A revised parameterization for gaseous dry deposition in air-quality models, Atmos. Chem. Phys., 3, 2067-2082, doi:10.5194/acp-3-2067-2003, 2003.

Zhao, C., Wang, Y., Choi, Y., and Zeng, T.: Summertime impact of convective transport and lightning $\mathrm{NO}_{\mathrm{x}}$ production over North America: modeling dependence on meteorological simulations, Atmos. Chem. Phys., 9, 4315-4327, doi:10.5194/acp-9-43152009, 2009. 